\title{
A TATÁRJÁRÁS RÉGÉSZETÉNEK ÚJABB TÁVLATAI KÉT KISKUNSÁGI LELŐHELY EREDMÉNYEINEK FÉNYÉBEN
}

\author{
Rosta SZABOLCS*
}

\begin{abstract}
A tanulmány két kiskunsági lelóhely tanulságai alapján a tatárjárás kérdéskörét taglalja. A kiskunmajsai és a Bugac közelében lévő Árpád-kori kolostort övező településen feltárt tömeggyilkosságok bizonyítékai kapcsán a korabeli források adatainak hitelességét vizsgálja.
\end{abstract}

Kulcsszavak: tatárjárás, tömeggyilkosság, éremkincs, antropofágia, Bugac-Pétermonostora

The study discusses the Mongol invasion based on the findings from two sites in the Kiskunság region. The mass graves containing the corpses of the mass murder of two communities uncovered at Kiskunmajsa and on the settlement around the Árpádian Age monastery near Bugac are set against the information contained in contemporaneous written sources in order to examine the latters' reliability.

Keywords: Mongolian invasion, mass murder, coin hoard, anthropophagy, Bugac-Pétermonostora

Az 1241-42. évi tatárjárás múltunk oly meghatározó és megrendítő eseménye volt, melyet közel 800 év elteltével is őriz a magyarság kollektív emlékezete.

Jelentőségének megfelelően a történettudomány is sokat foglalkozott az események feltárásával, magyarázatával. Az Árpád-kori Magyarország történelmének talán legjobban dokumentált rövid időszaka ez a pár év, hiszen a kortársak számára addig nem látott erejú támadást, valamint a vele együtt járó brutális pusztítást kiemelt figyelem övezte itthon és külföldön egyaránt. Történészgenerációknak nyújtott szinte állandó vitatémát a korabeli források felhasználhatóságának kérdése, ezzel együtt a pusztítás mértéke, annak rövid és hosszú távú hatásai. Az eltéró szempontú kritikai vizsgálatok eredményeként a források hitelességének kérdésében egymástól eltérő válaszokat adott a történettudomány. ${ }^{1}$

A kézirat beérkezett: 2017. december 2.

* Rosta Szabolcs: Katona József Múzeum, H-6000 Kecskemét, Bethlen körút 1.; e-mail: rosta@kkjm.hu
Az írott források gazdagságához képest a régészet hosszú időn keresztül nem tudott felvonultatni meghatározó eredményt a tatárjárás történéseinek igazolására. ${ }^{2} \mathrm{Az}$ egykori eseményekre utaló „kézzel fogható” bizonyítékot leginkább csak az idetartozó, föld be rejtett éremkincsleletek horizontja jelentette. A korabeli - gyakran apokaliptikus hangulatú - leírásokból amúgy következtethető, üszkös romokkal együtt járó tömeges gyilkosságok egyértelmú és hitelt érdemlő nyomai ellenben sokáig rejtve maradtak. A kevés kivételt jelentette az 1952-ben feltárt esztergomi leletegyüttes, ahol egy leégett és összeomlott épületben feküdt egy Fettich Nándor által ötvös-

1 A téma legfontosabb összefoglalásai: ZICHY 1934; FÉLEGYHÁZY 1943; GYÖRFFY 1963, 53-58; SZABÓ 1971, 174-181; BOROSY 1991; FÜGEDI 1992; SzÚCS 1993, 3-15; ENGEL 2001, 88-91; B. SZABÓ 2007. A történeti források első gyújteménye: A tatárjárás emlékezete 1981. A források és az interpretációk legteljesebb gyújteménye: Tatárjárás 2003.

2 A régészeti kutatások és megközelítések összefoglalása: LASZLOVSZKY 2003. A kérdéskörhöz kapcsolható régészeti emlékanyag első összegyújtése egy kiállításon: RITOóK-GARAM 2007. 
nek meghatározott áldozat. ${ }^{3}$ Az ezzel kapcsolatban talán kevésbé idézett másik jelenség a szabolcsi földvár közelében, Kisfaludon került elő az 1971-74 között folytatott ásatások során, ahol az Árpád-kori telep egyik gabonatároló vermébe dobott egyén halálát hozta összefüggésbe a tatárjárással Fodor István. Itt az Árpád-kori, földbe mélyített házakból bőséges fémanyag is felszínre került. ${ }^{4} \mathrm{~A}$ régészeti feltárások számának növekedése révén az 1970-80-as években kezd majd sokasodni azoknak a lelőhelyeknek a sora, ahol még csak telepjelenségek alapján - kétségtelenül egy 13. század közepére tehető pusztulási horizontot lehetett régészetileg kimutatni. ${ }^{5} \mathrm{~A}$ tatárjáráshoz köthető egyértelmú jelenségek alacsony száma, a közvetlen bizonyítékok hiánya, a leletszegénység egyúttal alátámasztani látszott azokat a nézeteket, miszerint a kortárs szemtanúk leírásai alapvetően túlzóak a pusztítás nagyságát és intenzitását illetően, és az események rekonstruálására nem vagy csak erős szúrőn keresztül használhatók fel. ${ }^{6}$

Az egykori forrásokból kiindulva a tatárjárásnak a kortársakat is megdöbbentő eleme az emberek brutális, tömeges legyilkolása volt. 199596-ban az M3 autópálya nyomvonalán, Hejőkeresztúr-Vizekköze lelőhelyen Wolf Mária tárt fel első ízben olyan helyszínt, ahol egyértelmúen a tatárjáráshoz kapcsolható kontextusban jelentkeztek fegyverek, használati tárgyak, valamint töredékes emberi maradványok egy épületen belül. Ezenkívül elszórva további vázrészek is voltak egyéb telepobjektumokban. Jelen ismereteink szerint legalább hat ember maradványaival lehet számolni e lelóhely feltárt részén. Ezt a jelenséget ráadásul egy igen konkrét eseményhez, a muhi csatához tudta kötni a feltáró régész. Pusztai Tamás 2001-ben szintén a muhi csata során vagy azzal összefüggésben elpusztult két ember gödörbe temetett vázát tárta fel a középkori Mohi településen. ${ }^{8}$ Majd a 2000-es évek közepétől kezdődik az „áttörés” a tatárjárás régészeti kutatásában, köszönhetően a nagy felületú, nagyberuházásokhoz kapcsolódó megelőző feltárásoknak, ahol lehetőség nyílt újabb lelőhelyek kutatására. ${ }^{9}$ 2005-2006-ban egy útépítéshez kapcsolódó ásatáson a Cegléd melletti Bürgeházidúlőben Gulyás Gyöngyi tárta fel a tatárjárás talán leginkább közismert, szívszorító pillanatképét. A földbe mélyített ház kemencéjébe bújt két kisgyermek és anyjuk csontvázának képe a sajtón keresztül országos nyilvánosságot is kapott. Hasonló leletekról a sajtóban sokasodó híradások nyomán került sor 2011-ben Kiskunfélegyházán arra a konferenciára, mely célzottan a tatárjárás témáját emelte középpontba. A Pálóczi-Horváth András 70. születésnapja tiszteletére megrendezett ülés és az előadásokból összeállított kötet olyan lelőhelyeket ismertet, melyek régészeti bizonyítékokra támaszkodva a pusztítás megdöbbentő valóságát idézik. ${ }^{10}$

$\mathrm{Az}$ újabb keletú régészeti sikerekben kétségtelenül kiemelkedő szerepet játszott a beruházásokhoz kapcsolódó nagy felületek vizsgálatának lehetősége. Ez nemcsak az emberi áldozatok és a pusztuláshoz kapcsolódó egyéb jegyek mennyiségi emelkedésével járt együtt, de egyúttal lehetóséget adott a többször csak önállóan vagy részleteiben mutatkozó jegyek összekapcsolására is. A 2004-2006 közt feltárt Orosháza-Bónum, a 2005-2006. évi, már említett Cegléd-Bürgeházi dúlő, a 2009-ben felszínre hozott DunaföldvárLó-hegy, majd a szintén az évben előkerült Szank-Haladás Tsz melletti épület olyan összetett, közvetlen bizonyítékokat nyújtó lelőhelyek, melyek korábban ismeretlenek voltak a magyar régészet számára. ${ }^{11}$ De minden jel szerint a tendencia tovább folytatódik, vagyis a tatárjárás brutalitásának kézzelfogható emlékei folyamatosan kerülnek elő a föld alól. 2013-ban Gallina Zsolt és Gulyás Gyöngyi tárták fel a gyilkos események egyértelmú nyomait Csanádpalota határában. ${ }^{12}$ Ugyanebben az évben Szörényi Gábor egy jelentős Árpád-kori leletanyaggal jelentkező településen, a Hernád magaspartján elterülő Onga-Nyárjas dúlő lelóhelyen talált egy rendellenes pózban fekvő áldozatot nyílheggyel a csigolyájában. ${ }^{13} \mathrm{Az}$ orosházi helyszín tapasztalataiból kiindulva Gyucha Attila és Rózsa Zoltán rövid összefoglalásukban összegyújtötték a pusztítás általuk ismert valamennyi lehetséges, régészeti szempontból értékelhető jellemzőjét. Ez a főként a nagyberuházások tapasztalatai alapján létrehozott analízistáblázat nagy segítséget jelent a kisebb felületeken mutatkozó jelenségek értelmezéséhez is, és kiváló kiindulópont az e témá-

3 FETTICH 1968.

4 FODOR 1975; FODOR 1976.

MiKLÓS 1991; DinNYÉS 1994; SZABÓ 2003.

6 A pusztítás mértékére vonatkozó elképzelések összefoglalása: LASZLOVSZKY 2007.

7 WOLF 1997; WOLF 1999; WOLF 2014.

8 PusZTai 2014; LasZlovsZKY-POW-PusZTai 2016.

9 A nagyberuházások hatása a tatárjárás régészeti kutatására: LASZLOVSZKY 2012.

10 ROSTA-V. SZÉKELY 2014.

11 Gyucha-RózSA 2014; Gulyás 2014; SZILÁGyI 2012; SzILÁGYISERLEGI 2014; WILHELM 2014.

12 Gulyás-Gallina 2014.

13 Szörényi Gábor szíves szóbeli közlése. Az anyag jelenleg még közöletlen. 


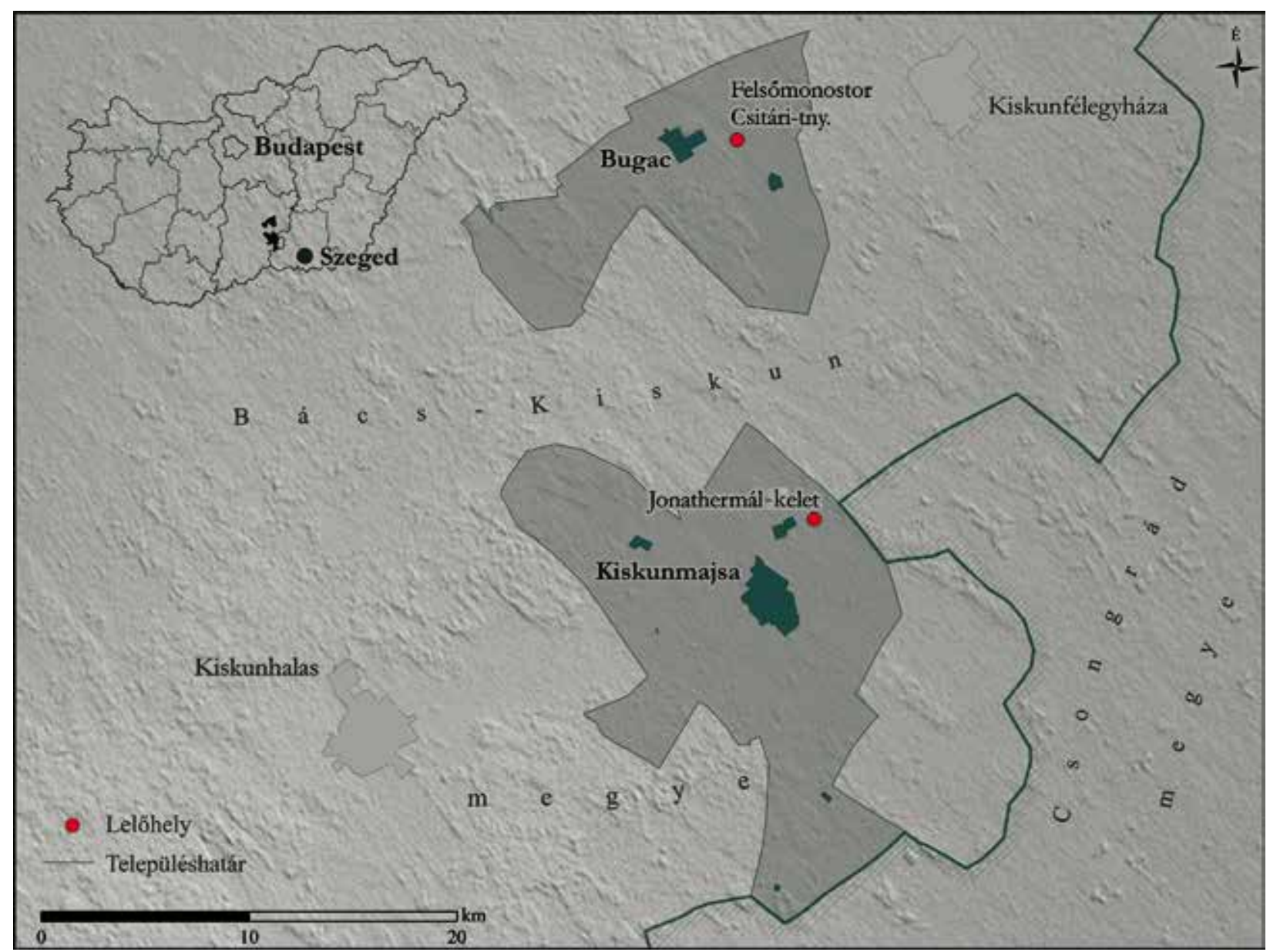

1. kép. Bugac-Felsőmonostor-Csitári tanya és Kiskunmajsa-Jonathermál-kelet lelőhelyek elhelyezkedése

Fig. 1. Location of the Bugac-Felsőmonostor-Csitári tanya and Kiskunmajsa-Jonathermál-kelet sites

hoz köthető további jegyek felismeréséhez, besorolásához. ${ }^{14}$

A következőkben ismertetett két lelőhely 2016. évi kutatása újabb komoly eredményt hozott a tatárjárás következményeit illetően (1. kép). Az előkerült jelenségek értelmezését nagyban elősegítették az elmúlt évtizedben feltárt és 2014-ben javarészt ismertetett lelőhelyek. Az eddigi tapasztalatokra építve a tatárjáráshoz köthető két új helyszínnel alkalom nyílik a pusztítás egyes jellegzetes motívumainak a meghatározására. Mindezeken felül az új eredmények lehetőséget teremtenek a kortárs beszámolók egyes vonatkozó adatai hitelességének alaposabb vizsgálatára is.

14 GYUCHA-RózSA 2014, 57, 67. A legfrissebb kutatások rövid összefoglalása és a legújabb kutatási területek bemutatása: LASZLOVSZKY-POW-PuSZTAI 2016. A tatárjárás kori kincsleletek tárgyai és azok kapcsolata a temetókben és településeken feltárt korabeli leletekkel: VARGHA 2015.

\section{Kiskunmajsa-Jonathermál-kelet lelőhely}

Múszeres lelőhely-felderítést folytattunk a kiskunmajsai fürdő mellett, az akkor alig néhány hónapja regisztrált Árpád-kori helyszínen 2016. március 13-án. A két éve telepített szőlőben a felszíni jegyek alapján előzetesen egy szétszántott temetót és egy gyenge intenzitású települést lehetett valószínúsíteni. ${ }^{15}$ Greman István múzeumbarát és Pánya István múzeumi munkatárs az egyik szőlőkaró tövénél először egy-egy, majd eredeti helyzetükből kimozgatva, de egy tömegben nagyszámú brakteátát talált. A kétségtelenül éremlelethez tartozó, általában összetapadt pénzek környezetében égett, hamus föld volt. A kis felületet érintő szakaszos mélyítés során egyre nagyobb tömegú törött és égett embercsont is

\footnotetext{
15 Az Árpád-kori lelőhelyet Wilhelm Gábor régész vezetésével terepbejárás során azonosították.
} 


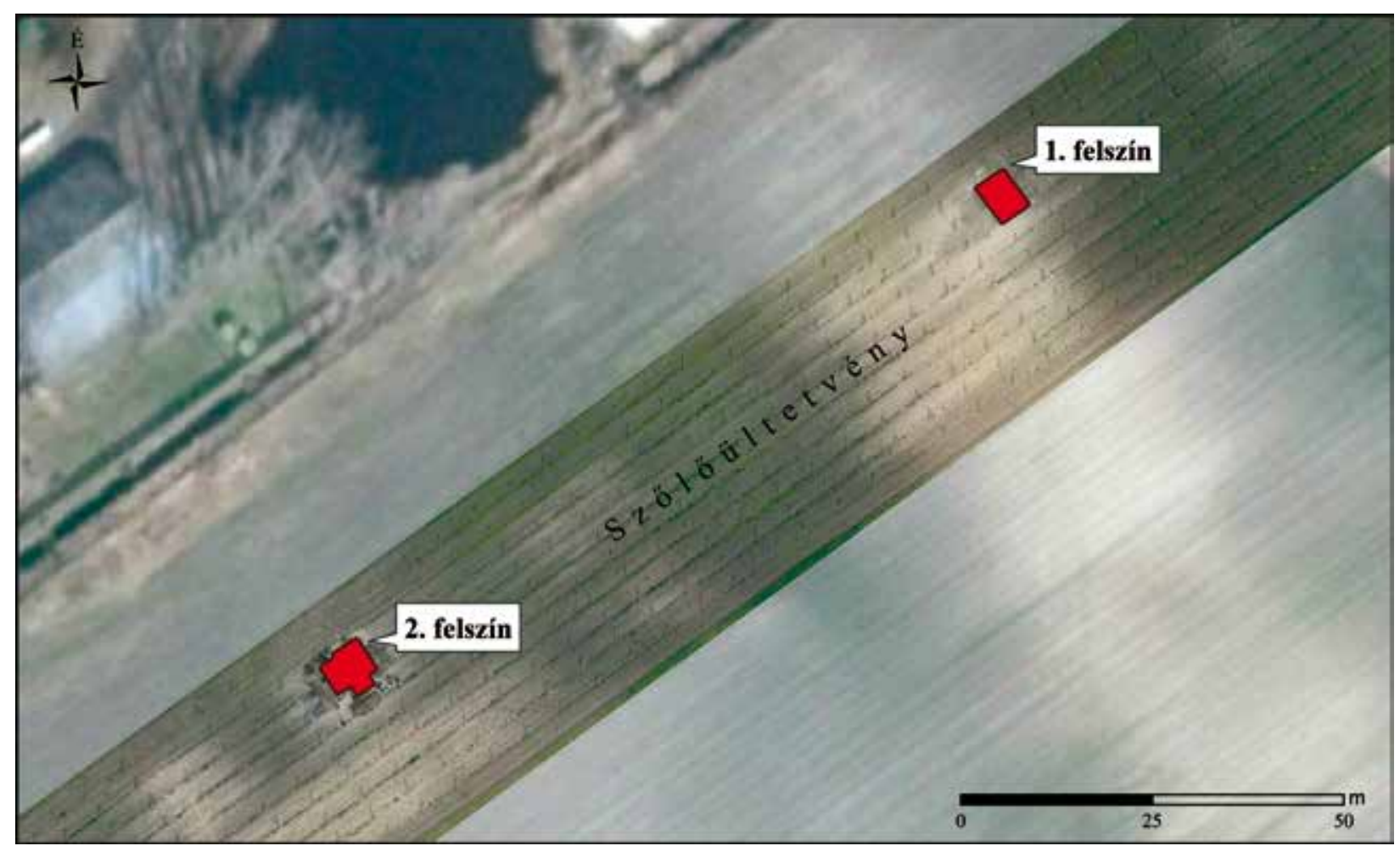

2. kép. Kiskunmajsa-Jonathermál-kelet. Ásatási helyszínek

Fig. 2. Kiskunmajsa-Jonathermál-kelet. Excavation locations

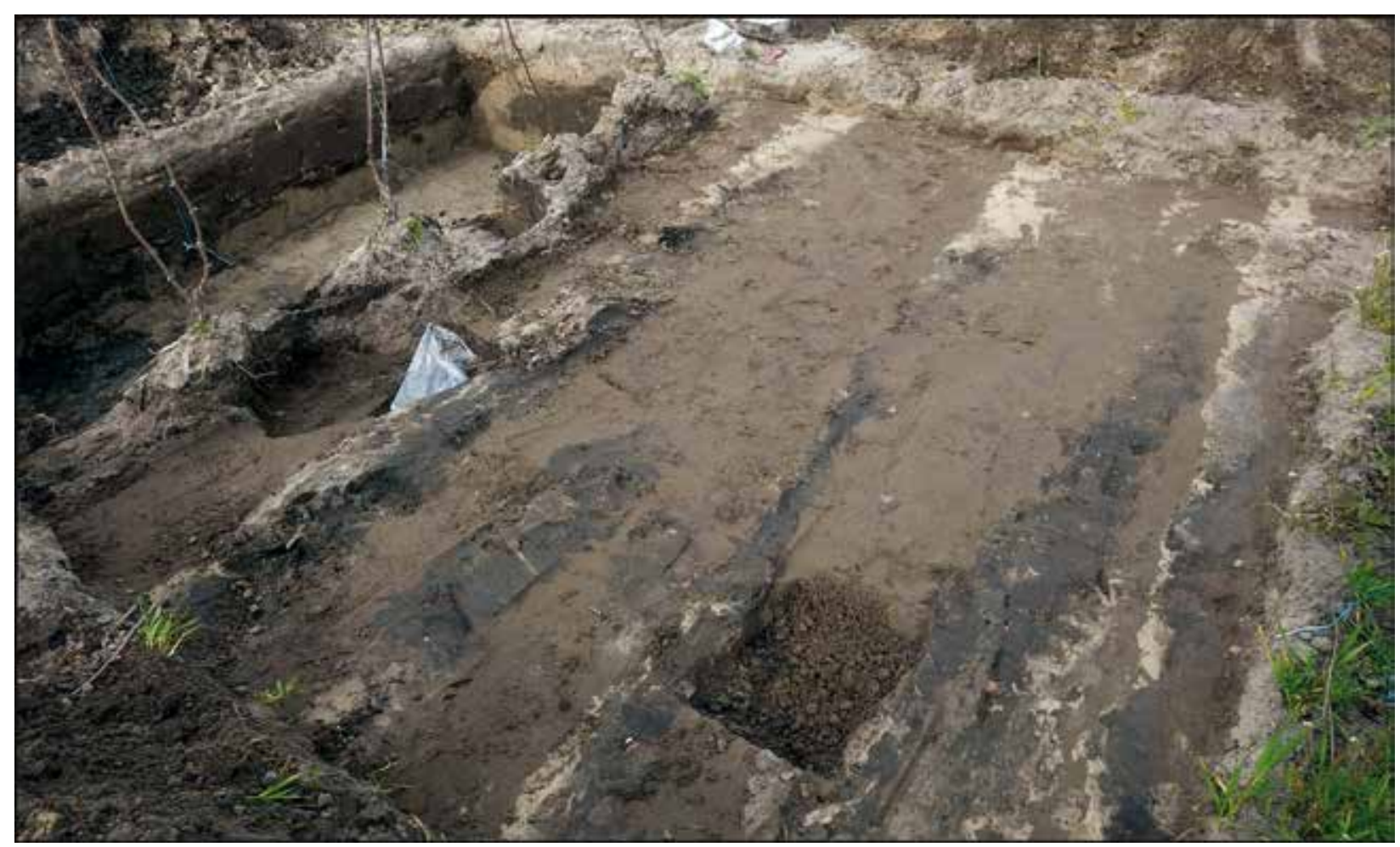

3. kép. Kiskunmajsa-Jonathermál-kelet. A szőlő alá forgatás következtében jelentkező hosszanti sávok

Fig. 3. Kiskunmajsa-Jonathermál-kelet. The longitudinal strips noted following vineyard maintenance work 


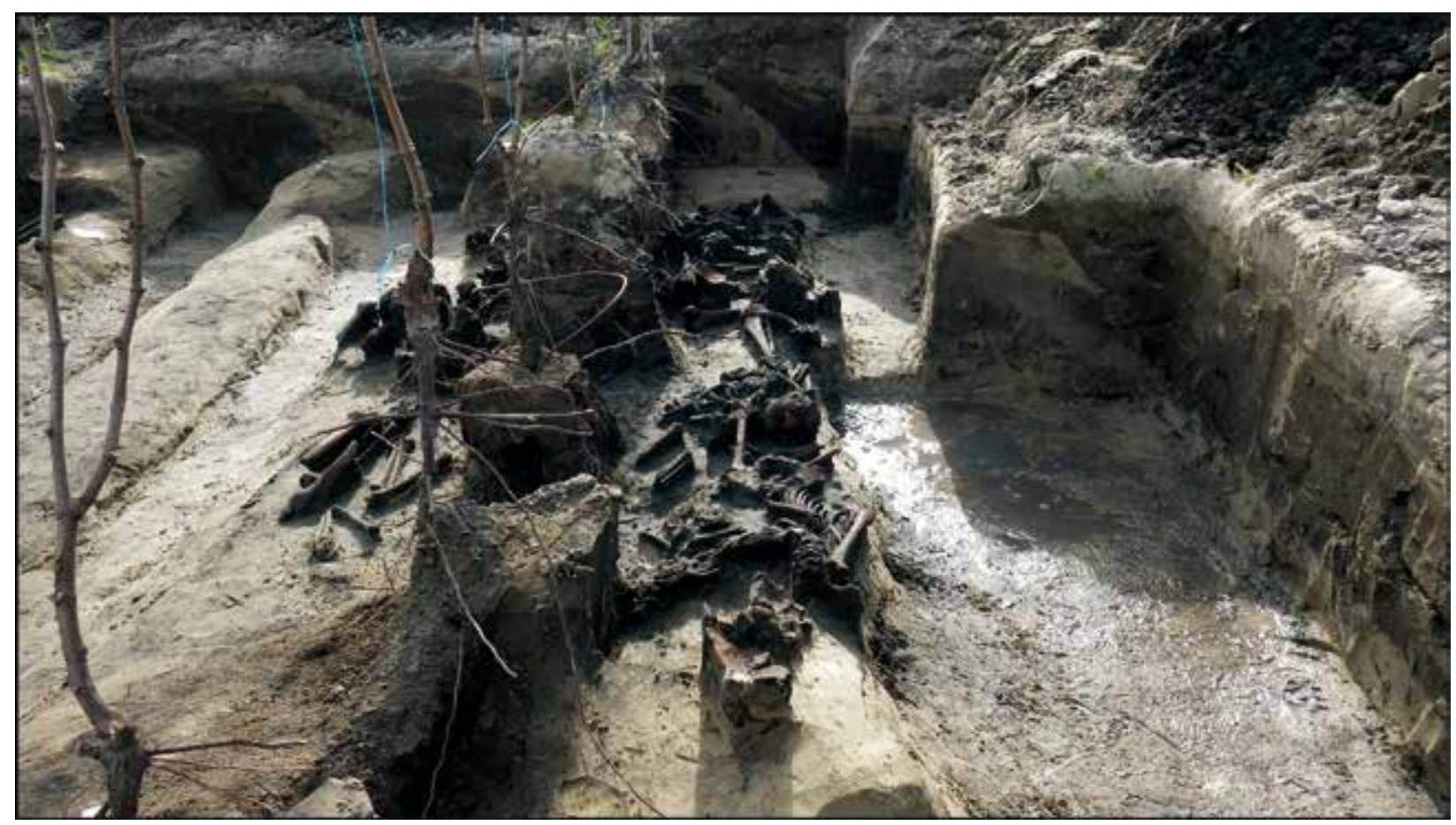

4. kép. Kiskunmajsa-Jonathermál-kelet. Részben eredeti helyzetükben megmaradt emberi maradványok az épület alsó részében

Fig. 4. Kiskunmajsa-Jonathermál-kelet. Human remains, partly in situ, in the building's lower part

előkerült. Az Árpád-kori településen koncentráltan jelentkező nagy tömegú égett embercsont és a brakteátákból álló éremlelet nyomán felmerült a gyanú, hogy a szomszédos Szankon 2010-ben észlelt jelenségkörrel lehet dolgunk. ${ }^{16}$ Ennek tisztázása érdekében 2016. március 28. és április 1. között a terület tulajdonosával történt egyeztetés után mentő feltárást végeztünk (2. kép). ${ }^{17}$

Mivel a felület megnyitásához egyetlen fogódzópontunk az éremlelet volt, értelemszerúen ennek környékén jelöltünk ki egy területet, ami az 1. felszín nevet kapta. A karósorok között kizárólag kézi erővel történt a felső réteg eltávolítása. A felszínen a felső $10 \mathrm{~cm}$ szürke homok (tárcsázás) alatt párhuzamos, egymástól élesen elváló hosszanti sávokban váltakoztak a sárga homok és a sötétebb, néhol égett humuszos homok be-

16 WiLHELM 2014.

17 Ezúton is köszönetünket fejezzük ki Nyerges Benjámin kiskunmajsai tanárnak, a szőlő tulajdonosának, aki kisebb mértékú, bár kétségtelenül látványos károkozásunk ellenére is engedélyezte munkánk folytatását. Hálás köszönettel tartozunk Greman Istvánnak, aki mind a lelőhely és éremlelet megtalálásának, mind a rákövetkező leletmentésnek kulcsfigurája volt. Litauszky Zoltán, az Ásatárs Kft. munkatársa, Andrássy Réka bajai és Vargáné Kocsis Zsuzsanna kiskunhalasi régészek, Sultis László bajai régésztechnikus, valamint Fogas Ottó szegedi régész-múzeumigazgató a leletmentés során nyújtott segítséget. töltései (3. kép). A barna csíkokból folyamatosan kerültek elő az embercsontok és egyéb leletek. Mind a feltárt részen, mind a tágabb környezetben is folyamatos fémkeresőzést folytattunk, melynek köszönhetően egyrészt valamennyi fémleletet „eredeti” helyzetéből szedhettük ki, másrészt a fémleletek és égett embercsontok szóródása alapján mintegy 115 méterre az 1 . felszíntól egy újabb leletkoncentrációnál kijelölhettük a 2. felszínünket is. A 2. felszínen hasonlóan jelentkeztek a mélyszántás alkotta sávok azzal a különbséggel, hogy a sötétebb, szinte fekete betöltések korommal, faszéndarabokkal keveredve mutatták, hogy egy erósen égett jelenséggel állunk szemben. Mindkét felületen általános volt, hogy anatómiai rendet mutató emberi vázrészek már a felszínen jelentkeztek. Ennek oka a mélyszántás forgatásában kereshető, ami a legtöbb esetben kimozdította a maradványokat, de egymáshoz viszonyítva nem teljesen húzta szét az összetartozó darabokat. Ezt a megfigyelést alátámasztották az egymás mellett lévő, eredeti helyzetükből ugyan kimozgatott, de egymáshoz képest csak alig széthúzott, összeilló nagyobb edénytöredékek is. A mélyszántás mintegy $80-100$ cm mélyen érintette a területet, a jelenségek nagyobb részét jelentősen roncsolva. A forgatóeke a bolygatatlan altalajból húzta be az egykori objektumokba a 


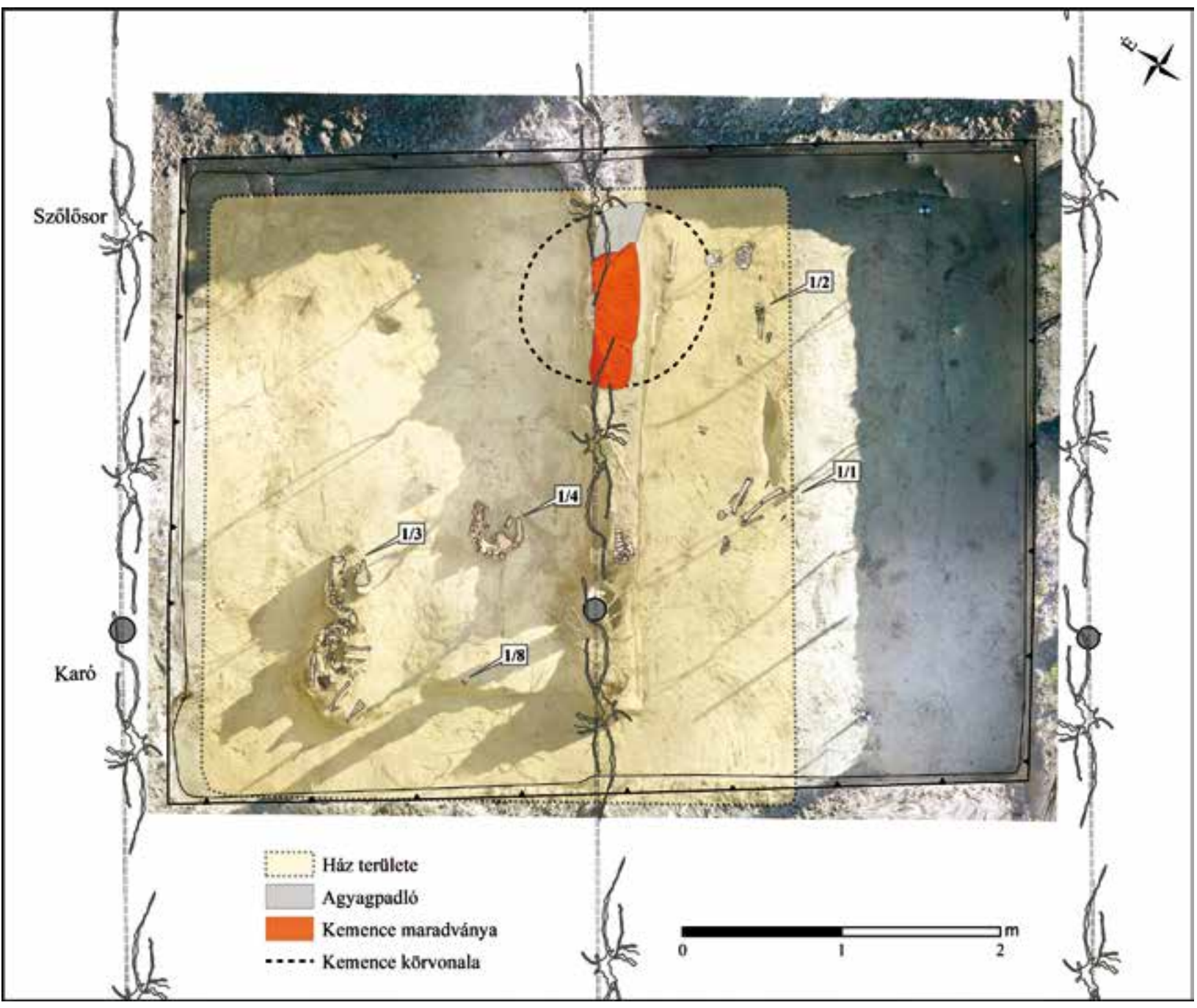

5. kép. Kiskunmajsa-Jonathermál-kelet. Az 1. felszínen jelentkező épület és a jelenségek felszínrajza

Fig. 5. Kiskunmajsa-Jonathermál-kelet. Plan of the building and other features in Trench 1

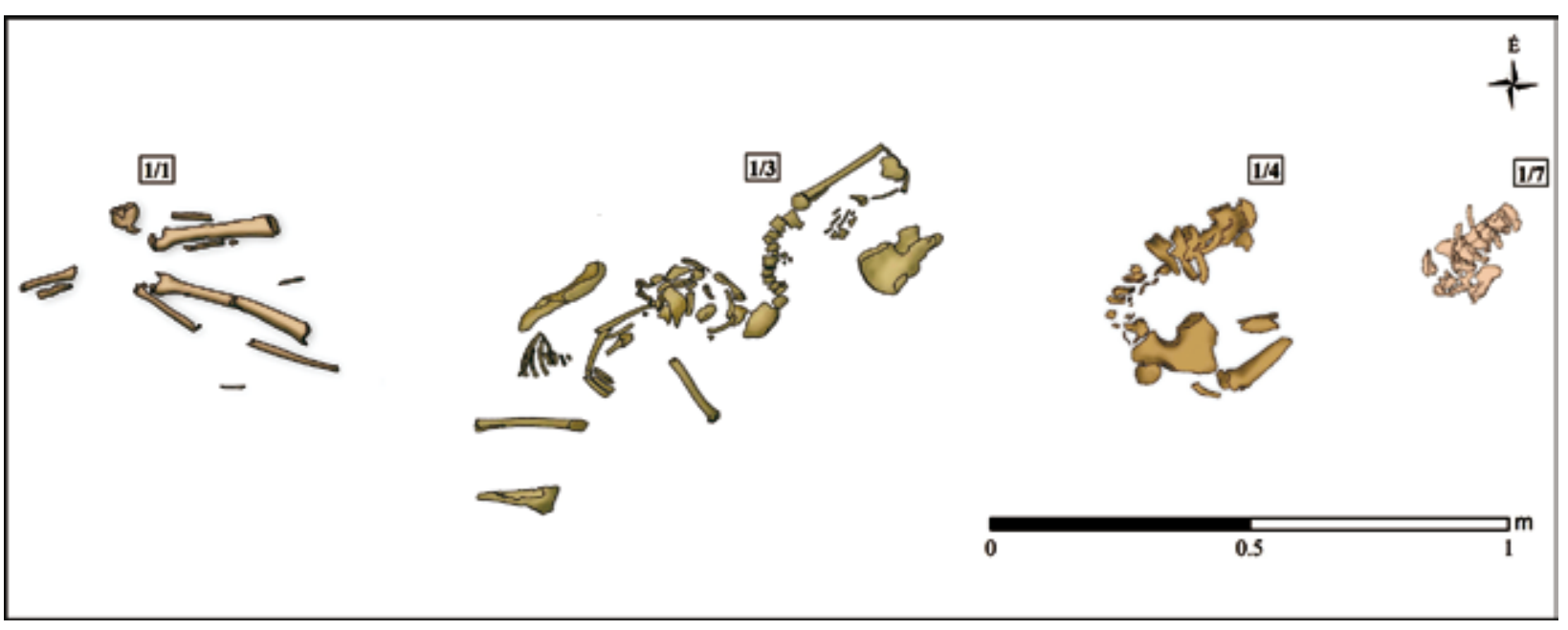

6. kép. Kiskunmajsa-Jonathermál-kelet. Az 1. felszín jelenségei: 1/1., 1/3., 1/4., 1/7

Fig. 6. Kiskunmajsa-Jonathermál-kelet. Features in Trench 1: Features $1 / 1,1 / 3,1 / 4$ and $1 / 7$ 
széles, intakt sárga homoksávokat, ezenkívül az objektumok betöltését is átmozgatta. Ennek következtében az egykori objektumok betöltése csak részben maradt eredeti környezetében, és annak egy jó része is elmozdult egykori helyzetéből a benne lévő vázakkal, vázrészletekkel és egyéb tárgyakkal egyetemben. A jelenségekhez alakítottuk a feltárási felületeket; a nehéz értelmezés ellenére is mondhatjuk, hogy alapvetően sikerült azonosítani az egykori építmények helyzetét. A két felszínen egy-egy földbe mélyített épületre, vélhetően házra ástunk rá. A mélyszántás okozta roncsolás nyomán az épületek nagyobb része ugyan megsemmisült, de az egykori padlószintek mélysége alá éppen csak az eke csúcsa ért le. A fordítás ferde jellegéből adódóan hosszanti sávokban ezért megmaradhatott az eredeti állapot (4. kép). Az egykori padlószinteken az érintetlen gerinceken lévő jelenségek így még a nagyfokú roncsolás ellenére is alkalmasak következtetések levonására. A betöltés felsőbb részein kimozgatott vagy a felszínre dobott embercsontok és kerámiadarabok, illetve a betöltésben fekvő, össze nem tartozó sok töredék miatt nem vázakat vagy edényeket, hanem jelenségeket, jelenségcsoportokat határoztunk meg. A jelenségek között egyértelmúen összetartozó és egymástól elkülöníthető vázrészletek, egymás közelében lévő nagy tömegú, eredetileg akár öszszetartozó embercsontok, illetve frissen széttörve egy kupacban vagy irányban elhúzva nagyobb edénydarabok voltak. Az egyértelmúen egymáshoz tartozó, anatómiai rendben lévő vázrészletek mellett vázcsoportok és szórványos csontok egyaránt kerültek egy jelenségbe. Így az ásatás körülményei között meghatározott, emberi maradványokra vonatkozó jelenségszám természetszerúleg nem fedi pontosan az antropológiai feldolgozás után mutatkozó egyedszámot. 18

A fenti helyzetből eredően a hagyományos dokumentálás is lehetetlennek bizonyult, így különösen jelentős szerepet kapott az elmúlt években a középkori templom körüli temetők esetében Pánya Istvánnal kidolgozott, és folyamatosan finomított térinformatikai alapú adatfelvételi módszer. A kecskeméti múzeum a kiskunmajsai lelőhelyen első alkalommal használt kizárólagosan 3D fotóval készült adatfelvételt. Ez sokkal pontosabb és gyorsabb volt, mint a kézi rajzolás,

18 Az embertani anyag feldolgozását Bernert Zsolt antropológus és Buzár Ágota biológus végezték el. Jelen kötetben szereplő tanulmányuk tartalmazza az ásatáson előkerült maradványok szakszerú antropológiai meghatározását és azok pontos leírását. A terepi körülmények között észlelt régészeti megfigyelés és a leírt jelenségek, illetve az antropológiai tanulmányban szereplő leírások között - a különböző szempontok miatt - némi eltérés tapasztalható. ráadásul a feldolgozás során is összehasonlíthatatlanul jobb eredményekkel szolgált, mint a korábbi módszerek. A szőlőkarókra rögzített fix pontok kihelyezését követően a betöltésben szerteszét előbukkanó jelenségek a körbefotózás után azonnal elbonthatók voltak, jelentősen meggyorsítva ezzel a feltárási munkát. Ezenkívül a jelenségek térinformatikai rendszerbe helyezésével az egymáshoz viszonyított helyzetük vizsgálata később, irodai körülmények között is lehetségessé vált egy 3D modellben. ${ }^{19}$

\section{1. felszín}

$\mathrm{Az}$ 1. felszín az éremlelet környezetében a folyamatosan előbukkanó jelenségek alapján kijelölt, 5,5×4,2 m nagyságú felület, mely három szőlőkarósor között feküdt. A feltárt területhez egy darab karó és egy sor szőlőtő tartozott, ezek némileg akadályozták a bontást. A környék legmagasabb pontján fekvő homokvonulat tetején a mélyszántás hatalmas pusztítást végzett, jelentősen megnehezítve az előkerült jelenségek értelmezését. A roncsolás az egykori földbe mélyített épület valamennyi oldalfalát érintette, mindöszsze a padlószint kisebb részei és egy kemence szelete maradt meg vékony sávokban. Így az épület kiterjedése minden irányban csak valószínúsíthető az eredeti helyzetben a padlón megmaradt vázrészletek szóródása alapján. Feltételesen egy ÉNy-DK tájolású, 3,5×4 m nagyságú, földbe mélyített épületet/házat rekonstruálhattunk (5. kép). Az egykori betöltés nagyobb hányada kikerült eredeti helyzetéből, a jelenségek is erősen töredékes állapotúak voltak. Nyolc jelenséget választottunk külön, melyek közül hat jelenség emberi vázrészekből állt, a két további lakóépülethez tartozott (kemence és padló). A számmal jelölt leletkoncentrációkon kívül számos további szórvány emberi csont- és kerámiatöredék is előkerült az átforgatott betöltésből.

\section{A jelenségek leirása}

1/1. Egy fiatal egyén anatómiai helyzetben lévő lábszára és talán egy alkarja. Igen magasan, nem a padlón, inkább a felszínhez közel feküdtek a maradványok. Egy embernek az eke által feldobott, részben egyben maradt vázrészeit lehet bennük azonosítani (6. kép).

19 Ezúton is szeretném külön köszönetemet kifejezni Pánya Istvának, akinek kreatív és innovatív gondolkodása és megoldásai elengedhetetlenek voltak e lelőhely felderítéséhez, feltárásához, dokumentálásához és feldolgozásához egyaránt. Az ortofotók alapján Vida Ágnes grafikus rajzolta át nagy pontossággal a jelenségeket, s ez az értelmezéshez és az antropológiai feldolgozáshoz is komoly segítséget jelentett. 


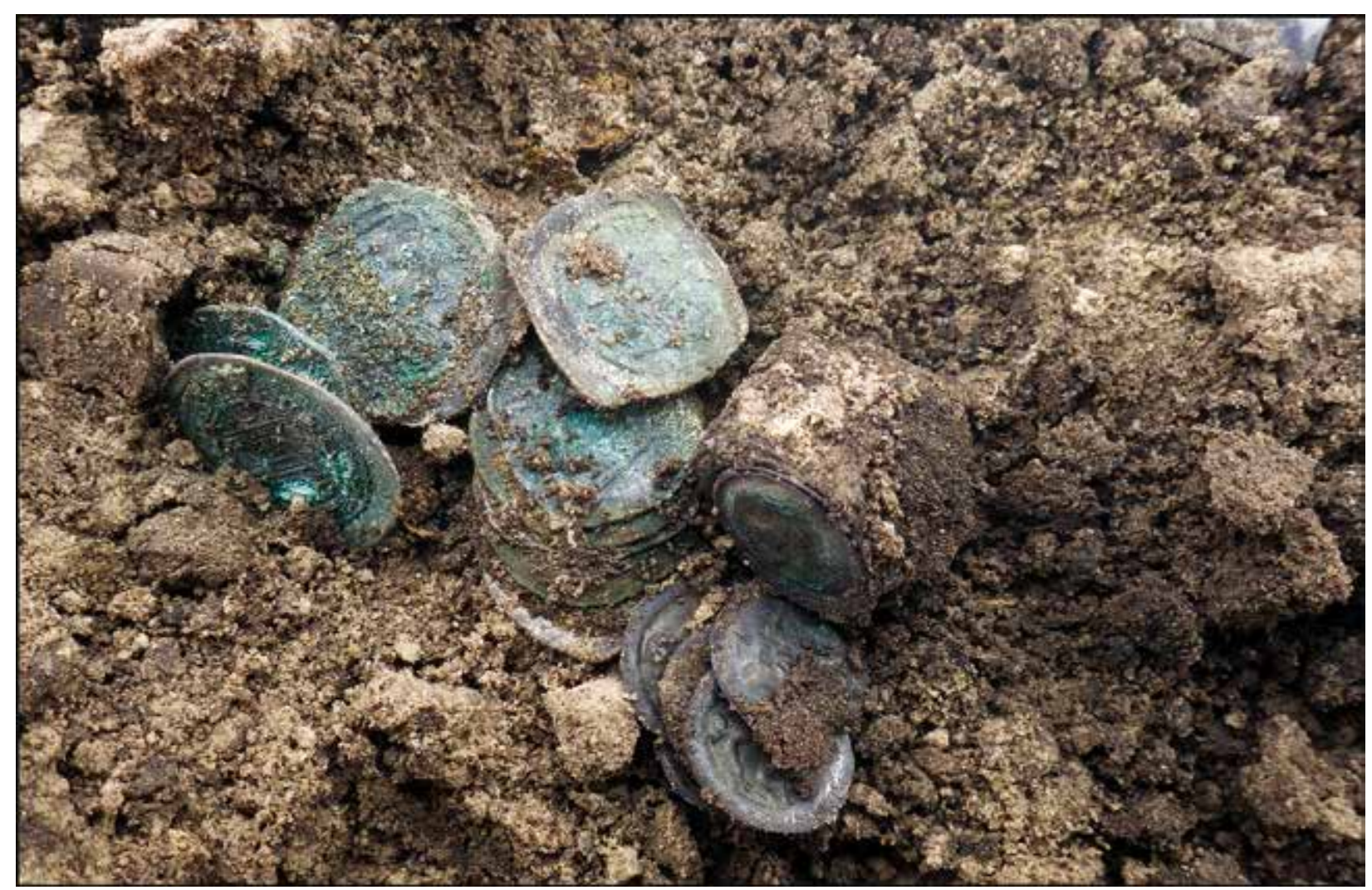

7. kép. Kiskunmajsa-Jonathermál-kelet. Az éremkincs előkerülése

Fig. 7. Kiskunmajsa-Jonathermál-kelet. Discovery of the coin hoard

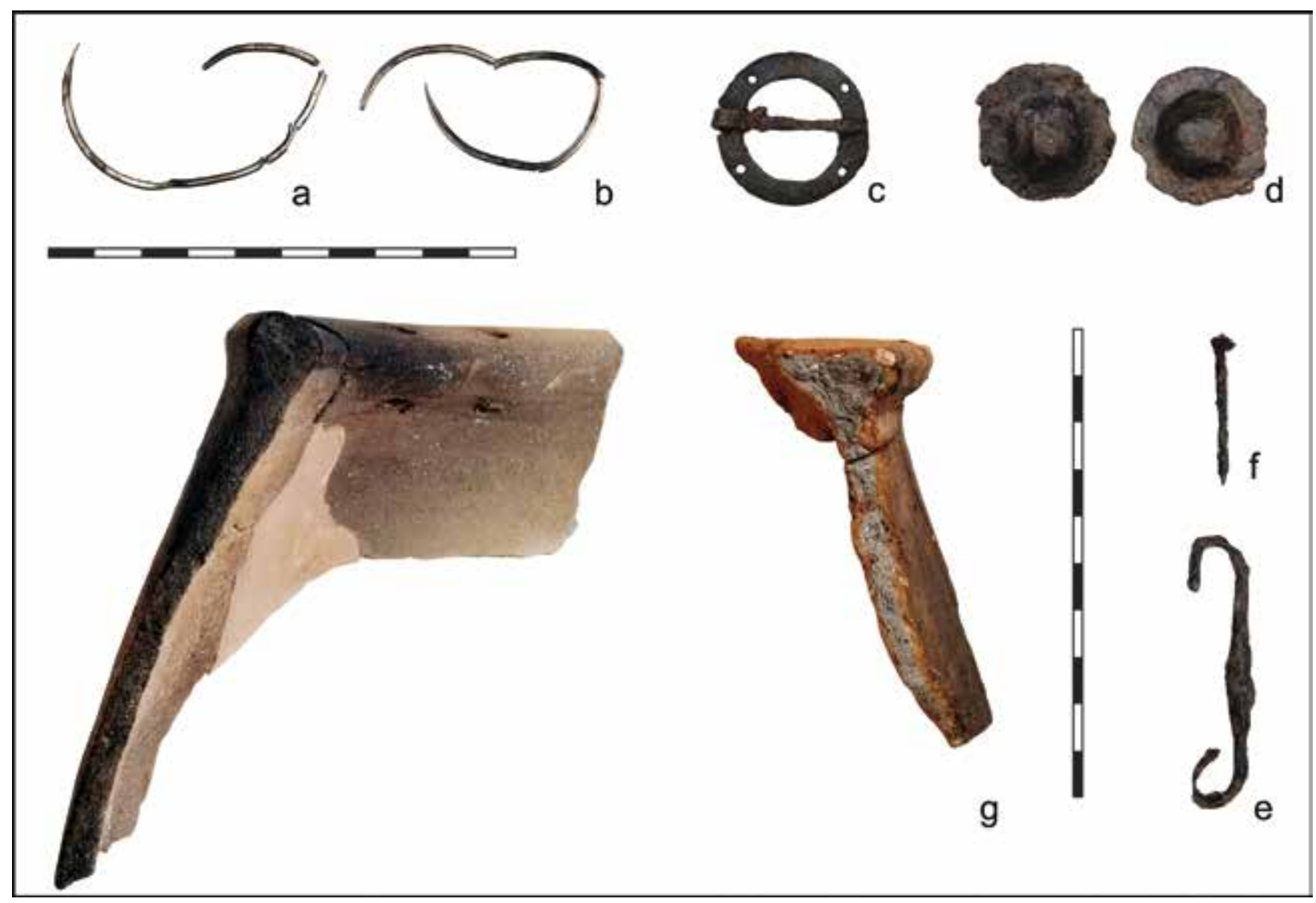

8. kép. Kiskunmajsa-Jonathermál-kelet. Az 1. épület tárgyleletei. a-b: ezüst fülbevalók; c: bronzcsat; d: vasveretek; e: vastárgy; f: vasszegecs; g: cserépbográcsok töredékei

Fig. 8. Kiskunmajsa-Jonathermál-kelet. Finds from Building 1. a-b: silver earrings; c: bronze buckle; d: iron fittings; e: iron artefact; f: iron rivet; g: fragments of clay cauldrons 
1/2. A jelenség kusza, töredékes, anatómiai rendben nem lévő kevés maradványból állt, talán több egyén darabjai, melyek szintén magasan, nem eredeti helyzetükben voltak.

$1 / 3$. Két ember részleges anatómiai rendben lévő vázrészei. A padlószinten feküdt egy hoszszabb, anatómiai helyzetben lévő meghajlított csigolyasor. Ettől kissé elkülönülve egy felsőtest részlete feküdt egy bordasorral (6. kép).

$1 / 4$. Egy nagyrészt anatómiai rendben lévő csigolyasor fél medencével kifordulva feküdt a padlószinten. Hozzá csatlakozott egy comb forgója, a töredékes comb kissé távolabb. A test a földbe kerüléskor minden bizonnyal erősen kicsavart helyzetben lehetett (6. kép).

1/5. Kemence. A szőlőtőkesor alatt épségben maradt vékony gerincen a padlóra épített kemence középső szelete maradt meg, nagyobb részét, a két oldalát megsemmisítette a mélyszántás. Az épen maradt részlet szerint az épületben egy a padlóra szürke agyagból épített kemence volt, sütőfelülete erősen átégett. A jelenségek szóródása alapján az épület ÉK-i oldalánál, de nem pontosan a sarokban helyezkedett el.

1/6. Padló. A szőlőtőkesor alatt épségben maradt vékony gerincen, a kemence előtt megmaradt egy kissé letaposott padlószakasz, amin az 1/7. számú emberi maradvány feküdt. Az épület további részein, az anatómiai rendben lévő vázrészek alatt nem volt érezhetően megkeményedve a padló.

1/7. A szántás alatt épségben megmaradt egy felnőtt medencéje, keresztcsontja és 4 csigolyája, melyek anatómiai rendben feküdtek a padlón. További részeit - ha voltak - a mellette futó két szántáscsík vitte el (6. kép). Az éremlelet alig 10 cm-re volt a csípőtől, így az elmozgatást is figyelembe véve akár ahhoz tartozhatott.

1/8. Magzat/csecsemő vázmaradványai. A nagyon apró hosszúcsontok egy része kimozdult a bontás során, mire észleltük; mindössze egy lábszár két csontja maradt eredeti helyzetében, anatómiai rendben. Az ugyaninnen kikerült további hosszúcsontok és ujjpercek ettől függetlenül jelzik, hogy részben legalábbis anatómiai rendben voltak a maradványok. A környezetében semmilyen felnőtt vázrész vagy akár csont sem volt, vagyis a csecsemő vagy magzat elkülönülten feküdt az anyjától.

\section{Tárgyleletek}

Éremlelet. A véletlenszerüen megtalált éremkincs darabjainak többsége a múszeres leletfelderítés során egymás mellól egy kupacban került elő. A leletmentés közben további szórványdarabok is elöjöttek, a „központi mag” maximum egyméteres körzetében. A mélyszántás miatt a pénzek többsége másodlagos helyzetben a szántás oldalára „kenődött fel” (7. kép). A mindösszesen 201 darab érme kétségtelenül egy leletegyüttes részét képezi. Mivel csak igen kevés szórványdarab volt, és az is a maghoz közel helyezkedett el, így nincs okunk azt feltételezni, hogy nagyobb mennyiségben húzott volna el az eke távolabbra is további pénzeket - azaz nagyságrendileg ennyi éremból állhatott a leletegyüttes. Gyaníthatóan nem egy elásott kincsleletről van szó. A pénzek valószínúleg az egyik áldozatnál a helyzete miatt talán az $1 / 7$. jelenségbe tartozó 25-35 éves felnőtt nőnél - lehettek valamilyen textilkörnyezetbe rejtve. ${ }^{20}$

Ezüstkarika. Roncsolt, enyhén deformált, nagyméretú, finom megmunkálású, vékony kerek átmetszetú huzalból készített karika, az épület betöltéséből jött elő. A huzal vastagsága 0,18 cm, a karika átmérője kb. $4 \mathrm{~cm}$. Egyik vége laposra kalapált, az így kialakított ovális alakú kiszélesedés külső felületén átlós irányú, karcolt díszítés van. A karika a szántás miatt ugyan torzult, egy helyen eltörött, de az előkerült darabok összeilleszthetők. A karikaékszer másik vége fokozatosan elvékonyodva, tompított hegyben végződik. A huzalon egyéb felerősítésnek, forrasztásnak nincs nyoma (8. kép a).

Ezüstkarika. Az előző karika párja, szintén deformálódott, de nincs eltörve, ép. Az előző karikával egyező technikával készült, a két darab tökéletesen egyforma méretú és díszítésú (8. kép b). Az épületen kívülről, attól 1-2 méterre jött elő felszíni fémkeresőzés során. A karika nem a szántás irányában volt, vagyis a szántás nem lehet az oka az esetleges kimozdításnak. Úgy túnik, hogy a párba tartozó karikák közül az egyik eredetileg sem került az épület betöltésébe.

Mindkét karikát másodlagos helyzetben találtuk: az elsőt az épületen belül a szántás mozgatta el, a másik távolabb, a külső felszínen feküdhetett. Helyzetük alapján az éremlelethez tartozásuk erősen kérdéses, valószínúbb, hogy az épületben lévő egyik női áldozat ékszerei voltak. Hegyes végük és finom kidolgozásuk alapján az ezüstkarikák nagyobb méretú fülbevalók lehettek.

Kerek bronzcsat. Az épület területén másodlagos helyzetben volt. Kerek, öntött, díszítetlen darab. Külső átmérője 3,3 cm. A négyzetes átmetszetû csatpecek vasból készült, és a csattestre korrodálódott. A négy, egyenletes elosztásban lévő kis lyuk segítségével varrták fel a csattestet

\footnotetext{
20 Az éremleletek feldolgozását V. Székely György és Nagy Balázs végezte el.
} 


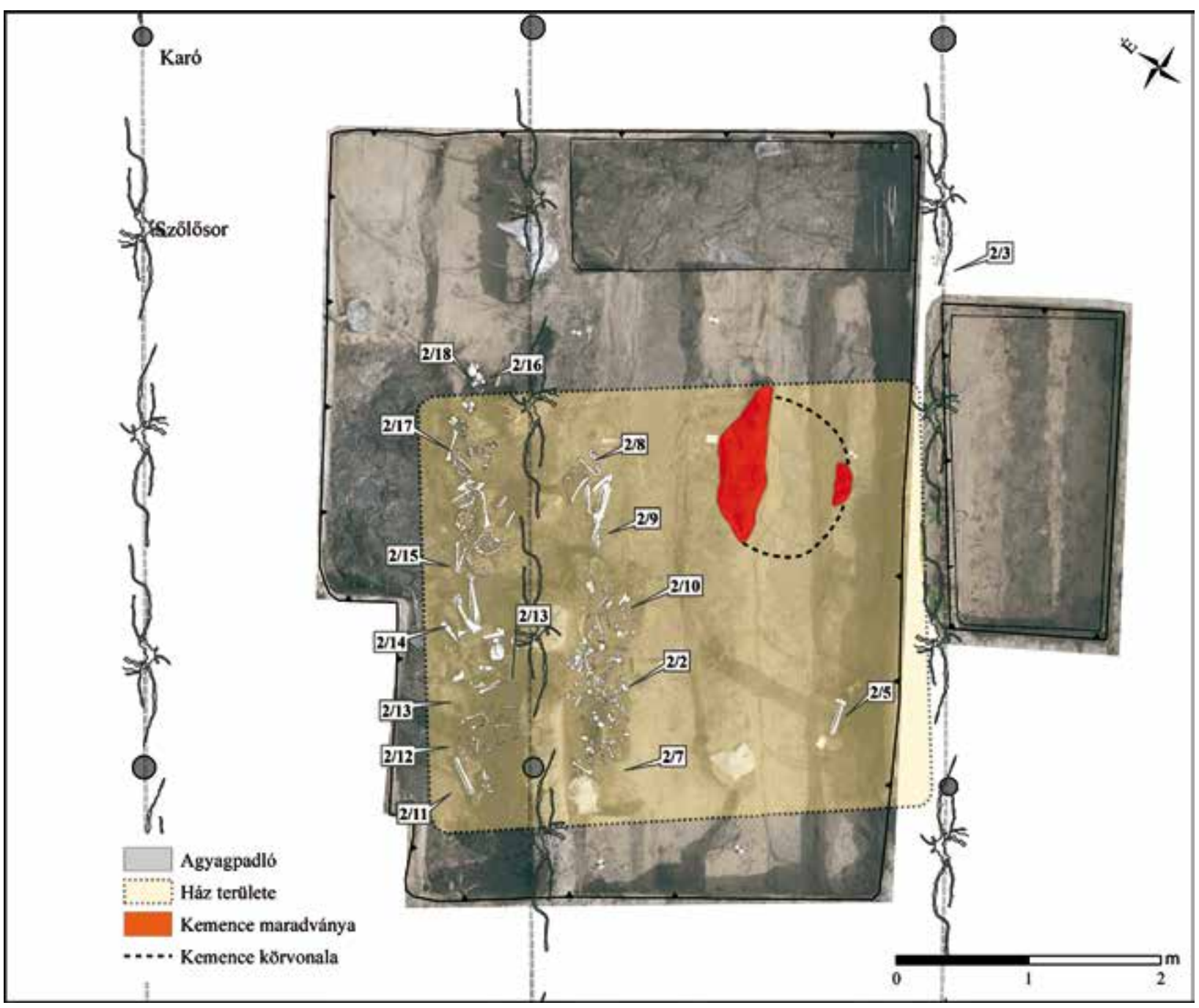

9. kép. Kiskunmajsa-Jonathermál-kelet. A 2. felszínen jelentkező épület és a jelenségek felszínrajza Fig. 9. Kiskunmajsa-Jonathermál-kelet. Plan of the building and other features in Trench 2
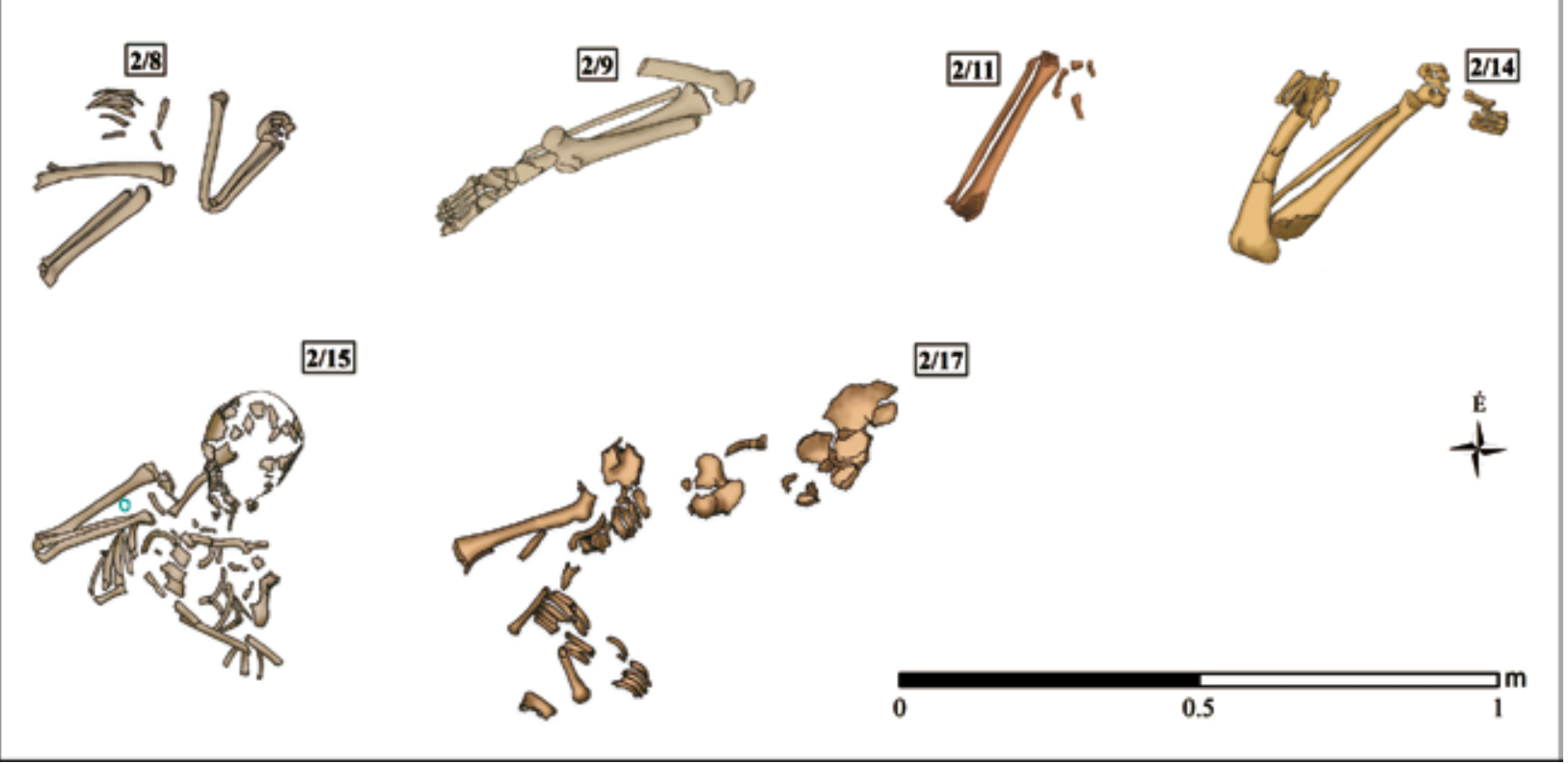

10. kép. Kiskunmajsa-Jonathermál-kelet. A 2. felszín jelenségei: 2/8, 2/9, 2/11, 2/14, 2/15, 2/17

Fig. 10. Kiskunmajsa-Jonathermál-kelet. Features in Trench 2: Features 2/8, 2/9, 2/11, 2/14, 2/15 and 2/17 
az ingre/könnyú köpenyre. Hasonló csatok díszítetlen vagy díszített, általában nemesfémből készült példányai általánosan elterjedtek a korszakban, több esetben megtalálhatók a tatárjáráskori kincsleletekben is. ${ }^{21} \mathrm{~A}$ bronzcsat a zárt együttest képezó éremlelettől távolabb feküdt, így az ezüstkarikákhoz hasonlóan nem a kincslelet részét képezte, hanem inkább az egyik áldozat ruházatához tartozhatott (8. kép c).

Vastárgyak. Az épület DK-i felében kimozgatott helyzetben egymás mellól előkerült két $3 \mathrm{~cm}$ átmérőjuu, kerek, pajzsdudorra emlékeztető kis tárgy, melyek hátoldalán megegyező, töredékes kar szolgálta a felerősítést. A darabok talán ládát, ajtót, bútort díszítő veretek lehettek (8. kép d). A kerek veretek mellett előbukkant egy vékony, négyzetes átmetszetû́, finom megmunkálású vastárgy, melynek közepe kissé kiszélesedő, végei vissza vannak hajlítva. A huzal esetleg zárhoz, lakathoz tartozhatott (8. kép e). Egy kisméretú, alig 3,3 cm hosszú, elkalapált fejú, vékony, négyzet átmetszetú szegecs finomságából és kis méretéból ítélve nem a födémszerkezetet erősítette, de nem is zsindelyszeg, inkább valamilyen bútor, kisebb láda erősítését szolgálta (8. kép f). A fentieken kívül a betöltésben további tíz meghatározhatatlan, töredékes vastárgyat találtunk.

Kerámiaedények. A betöltésból két, részben kiegészíthető cserépbogrács nagyobb töredékei kerültek elő. Az össze nem illő darabok alapján mindkét bogrács egész lehetett a mélyszántást megelőzóen, és a háztartás felszereléséhez tartoztak (8. kép g).

\section{2. felszin}

A második felület a felszíni leletkoncentráció, majd az égett betöltés és a jelenségek alapján kijelölt mintegy $5,7 \times 4,4 \mathrm{~m}$ nagyságú terület volt három szőlókarósor között. A feltárt területhez egy darab karó és egy sor szőlőtő tartozott. A feltárás DNy-i irányban egy további, 1,3×2,5 m nagyságú rábontást igényelt. A feltárást a csontok alapvetően rossz állapota mellett az épület alján jelentkező talajvíz is nehezítette. A 2. felszínen lévő épület mélyebb területen fekszik, így a szántás kisebb mélységben károsította. A földbe mélyített épületnek legalább két oldala és a kemence helyzete pontosan rekonstruálható (9. kép). A szántatlan csíkokban sikerült kibontani az ÉNy-DK irányítású épület szántásokra meröleges oldalfalának kisebb szakaszait. Az épület szélességét 3,2 méterben határozhatjuk meg.

21 KovÁcs 1973, 80-84; PARÁdI 1975, 119-161; JAKAB 2007, 264; WILHELM 2014, 88.
A hosszanti, széles szántáscsíkok elpusztították az épület két rövidebb oldalát, azonban az égett betöltés azt egyértelmúen jelezte, hogy mely szántáscsíkokban nem található már kormos, faszenes betöltés. Az ÉNy-i rövidebb oldal és a Ny-i sarok meghatározását a vázmaradványok elhelyezkedése is segíti. Így megközelítóleg 0,5 $\mathrm{m}$ pontossággal meghatározható az épület hoszszúsága is, mely 3,5-4 m között lehetett. Cölöphely az épületen belül nem mutatkozott, és mivel a mélyszántás az egyébként nem letaposott padlószintnél még a kimozgatott csíkokban sem sokkal mélyebben végzett roncsolást, így az valószínúsíthetően eredetileg sem volt. A 2. épület kisebb károsodása és a vázak eleve magasabb száma miatt nagyobb jelenségszám mutatkozott, mint az 1. felületen. Ráadásul maguk a jelenségek is - melyek közül két kerámiaedényen és a kemencén kívül 15 jelenség emberi maradványokhoz köthető - jelentősen jobb állapotban maradtak meg. A vázrészek többségükben jól elkülöníthetők és értelmezhetők voltak.

\section{A jelenségek leírása}

2/1. Kerámia

2/2. Nagyobb mennyiségú, szántás által bolygatott, másodlagos helyzetú embercsonttöredék kusza állapotban a betöltés felső részén.

$2 / 3$. Fiatal egyén anatómiai rendben fekvő lábszártöredéke magasan, az eke által bizonyosan elmozgatott helyzetben. Mellette még egy alkar és egy további lábszárcsont volt, talán ugyanannak a fiatalnak a maradványai.

2/4. Kerámia

2/5. Egy felnőtt egyén jobb lábszára, bokája és néhány ujjperce anatómiai rendben feküdt a padlószinten az épület Ny-i sarkánál, a többiektôl elkülönülten, magányosan. Nem volt a közelében nagyobb tömegú csont, a többi vázrészt elvihette a szántás.

2/6. Kemence: az épület ÉK-i hosszanti oldala mentén, nem teljesen a K-i sarokba épült kemencének a két széle maradt meg. A padlószintre épített kemence közepét a teljes sütófelülettel együtt elvitte a mélyszántás. A megmaradt oldalak alapján a boltozat szürke agyagból volt felépítve.

$2 / 7$. A jelenséget nagyobb tömegú, minden bizonnyal több emberhez tartozó csont alkotta az eke által bolygatott állapotban a betöltés középső részén. A 2/10. jelenséggel együtt kezelendő, annak felső részét jelenti. A csontok között „S végú" bronz karikaékszert találtunk.

2/8. Egy kisgyermek jól értelmezhetó maradványai részleges anatómiai rendben hevertek az épület közepén, a padlószinten. Egy behajlított kar és egy láb, mellettük a szántás által alig ki- 

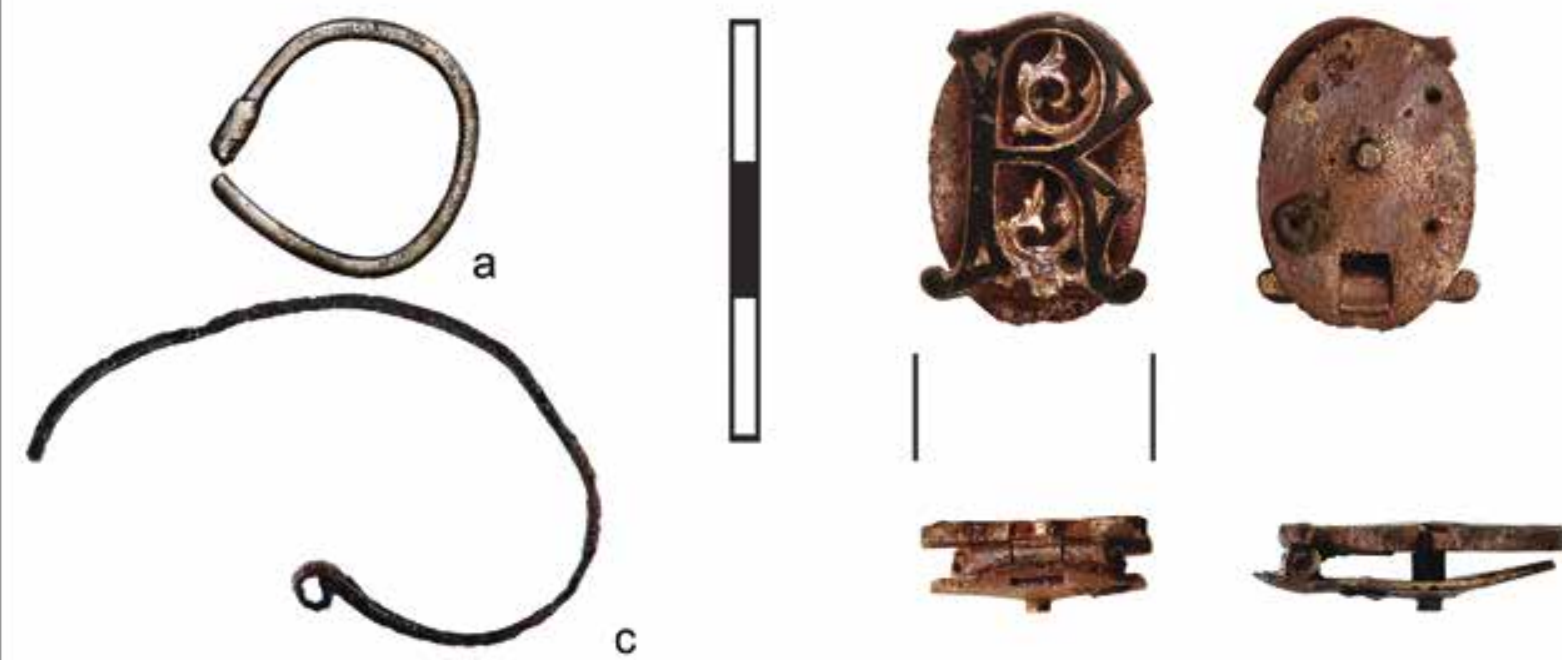

b

11. kép. Kiskunmajsa-Jonathermál-kelet. A 2. épület tárgyleletei. a: köpüs ezüstkarika; b: zománcozott veret; c: „s" végú bronz karikaékszer

Fig. 11. Kiskunmajsa-Jonathermál-kelet. Finds from Building 2. a: silver ring; b: enamelled fitting; c: S-terminalled bronze ring

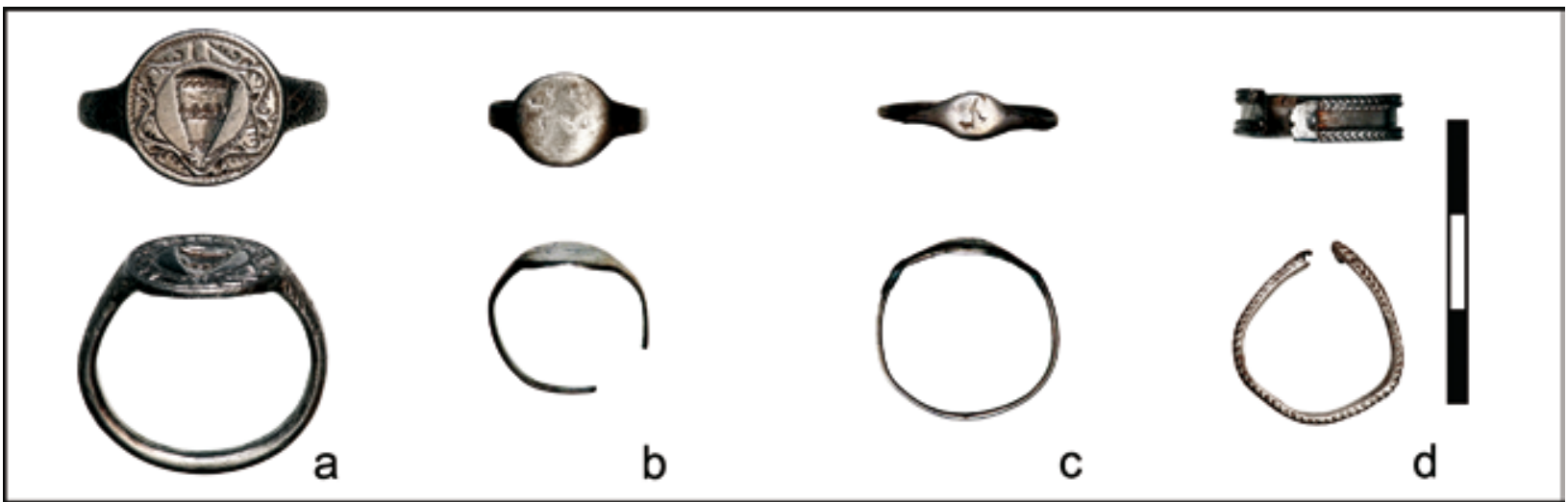

12. kép. Kiskunmajsa-Jonathermál-kelet. A 2. épület tárgyleletei. a: ezüst pecsétgyưrú; b-c: ezüst fejesgyưrúk vésett díszítéssel; d: filigrándíszes ezüstgyưrü pántja

Fig. 12. Kiskunmajsa-Jonathermál-kelet. Finds from Building 2. a: silver signet ring; b-c: silver finger-rings with engraved bezel; d: filigree-decorated hoop of a silver finger-ring

mozgatott több borda jelölte az elpusztult felsőtest elhelyezkedését. Néhány ujjperc a combtónél megmaradt. Az anatómiai rendben lévő maradványok a padlón összezsugorodva fekvő kisgyermek testére engednek következtetni (10. kép).

2/9. Egy felnőtt bal láb a padlón, melynek combcsontja a szántás miatt eltörött. A láb térdból teljesen visszahajlik, a talprész felfelé néz. Ezt az anatómiai helyzetet a megmaradt vázrész önmagában nem engedte volna, hiszen ehhez az „ülo" pozícióhoz a felsőtestnek a lábra nehezedésére is szükség volt. Így szinte biztosra vehető, hogy az épületbe kerülésekor a lábhoz tartozott további felső rész is, melyet legkésőbb a szántás vitt el. A jobb oldalát szintén a szántás pusztíthatta el (10. kép).

2/10. A 2/7. jelenség alatt feltárt, nagy mennyiségú, több emberhez tartozó csonttörmelékréteg, amiben semmilyen anatómiai rendet nem lehet észrevenni a maradványok között.

2/11. Egy kisgyerek anatómiai rendben lévő lábszára és lábfeje (10. kép).

2/12. Több egyén hosszan elnyúló, nem anatómiai rendben lévő csontjai a padlószint magasságában az épület ÉNy-i oldalában. E csontok el- 
helyezkedése segíti az épület Ny-i sarokrészének a pontos meghatározását.

2/13. Egyetlen anatómiai rendben lévő alkar, a váz további darabjai talán a mellette lévő jelenségekben vannak.

2/14. Egy felnőtt bal lába és lábfeje anatómiai rendben. A 2/9.-hez hasonlóan erósen fel volt húzva a láb, szinte visszatörve, bár itt a talp nem felfelé áll, a lábfej az oldalán nyugszik a padlón. A comb tövénél volt több ujjperc, ami a kézfej helyzetét mutatja. A test további, nagyobb részét elvihette a szántás, bár eleve furcsa módon, ellentétes irányban fekszik a 2/15. nő alsóteste helyén (10. kép).

2/15. Felnőtt nő jól értelmezhető vázrészlete. A koponya egyenesen előre néz, a felsőtest jobb oldala is bolygatatlan. A jobb alkar erősen a jobb vállig visszahajlítva. A felkar mellett egy köpús ezüstkarika volt. A felsőtest oldala kissé bolygatott, a vázcsontok deréktól lefelé hiányoznak. Ebben az esetben a roncsolást nem lehet kizárólag a szántás számlájára írni, mivel a derék folytatásában egy újabb anatómiai rendben lévő maradvány, a 2/14-es láb van. Ez a helyzet mindenképpen felveti annak lehetőségét, hogy talán már eleve nem teljes anatómiai rendben kerültek egyes vázak az épületbe (10. kép).

2/16. Gyermekhez tartozó két töredékes lábszár, melyek egymáshoz képest párhuzamosan fekszenek. Az anatómiai rend és a szántást megelőző csatlakozó részek ennek alapján valószínúsíthetők.

2/17. Egy padlón fekvő kisgyerek vázának jól értelmezhetó nagyobb része. A test a hátán feküdt, a jobb lába erősen vissza volt hajlítva a szeméremcsontig, a térdet elvitte a szántás. A felsőtest bal oldala ép volt, a jobb a mélyszántás áldozatául esett. A bal alkar helyzete kérdéses, a bolygatott csontok között két csonk is van, ezek megfelelhetnek neki - vagy keresztben volt a hason, vagy erósen fel volt húzva (10. kép).

$2 / 18$. Több váz maradványai, melyek közül bizonyosan elkülöníthető egy felnőtt egyén jobb vállöve a felső csigolyasorral és a szántás által elhúzott és széttört koponyája.

\section{Tárgyleletek}

Ezüstkarika. Kerek átmetszetú huzalból készített, $2 \mathrm{~cm}$ átmérőjú, díszítetlen ezüst karikaékszer. Egyik fele vágott, a másik köpúben végződik. Az egyetlen kétségtelenül eredeti helyzetben lévő tárgylelet, ami a 2/15. női váz jobb felkarja felső részénél, annak belső oldalánál feküdt. Semmiképpen sem fülbevaló volt, valószínúleg az áldozat hajában, talán egy copfba fúzve lehetett (11. kép a).
Zománcozott tárgy. Bronzból készült, öntött, aranyozott, magas színvonalon és finoman megmunkált, előlapján fekete zománccal díszített „R" maiusculát formázó veret. A tárgy ovális hátlapját kisebb zsanér kapcsolja egy előlaphoz, ilyen módon a tárgy „lenyitható". A hátlapon négy apró lyuk mutatja a felerősítés helyét, melynek környékén korrózió jelzi, hogy egykor apró vasszegecsekkel volt felerősítve. Középen egy az elólapból hátrafelé kiinduló kerek átmetszetú bronzszegecs illeszkedik a hátlap előoldalához erősített üreges csövecskébe, kicsit túlnyúlva azon, ez a tárgynak egyfajta patent jellegú felerósítését szolgálta. Az elólap és hátlap által közrefogott kis távolság alapján leginkább egy vastagabb bőrszíjra, esetleg vékonyabb fa-fém lemezre lehetett felerősítve. E bonyolultnak túnő, hátlapos, patentos-zsanéros megoldással azt érték el, hogy a kifinomult maiuscula-ábrázoláson kívül semmilyen, az összképet romboló dolog nem látszik az előoldalon. A zsanér szabad mozgásának biztosítása korlátokat szab a rendeltetésre vonatkozó feltételezéseknek (11. kép b).

$S$ végü karika. Vékony bronzhuzalból készített, erősen deformált karikaékszer (11. kép c).

Gyürűk. Az épület közepéről négy darab ezüstgyưrü került elő gondosan egymásba rakva, közéjük szorosan - az értékeket szándékosan kis csomagba tömörítve - több pénzérmét is helyeztek. A gyûrúk a pénzekkel együtt egy kincslelet részét képezhetik. ${ }^{22}$ Pecsétgyúrü: ép állapotú, jó megtartású, a fej felé fokozatosan kiszélesedő pántú ezüst pecsétgyưrú. A gyưrúfejen két gyöngykör között leveles indadísz, amelyet felül két függőleges pontsor oszt meg. A belső gyöngykörben, középen enyhén ívelt oldalú háromszögpajzs, négy keskeny és kettő szélesebb sávozattal. A keskeny sávok (pólyák) közül három ferde sormintával díszített, a két szélesebb és a legalsó keskenyebb díszítetlen. A gyưrüfej két oldalán apró pontsorokkal kialakított rombuszháló, a rombuszok közepén apró mélyedéssel (12. kép a). Fejesgyürü: ép állapotú, erősen kopott, a kerek fej felé fokozatosan kiszélesedő pántú ezüst fejesgyưrú. A gyưrú fején erősen megkopott, jobbra haladó négylábú állatot ábrázoló vésett díszítés (12. kép b). Fejesgyürü: ép állapotú, erősen kopott, a fej felé fokozatosan kiszélesedó pántú ezüstgyúrú. A pánt erősen megkopott, kiszélesedő részén nehezen kivehető, talán liliomszerú vésett díszítés látható (12. kép c). Fejesgyürü pántja: jó megtartású ezüstpánt, amelyre eredetileg

\footnotetext{
22 Az érmek leírását V. Székely Györgynek és Nagy Balázsnak e kötetben megjelenő tanulmánya tartalmazza. A gyúrúk leírása részben V. Székely György kéziratban maradt munkája.
} 


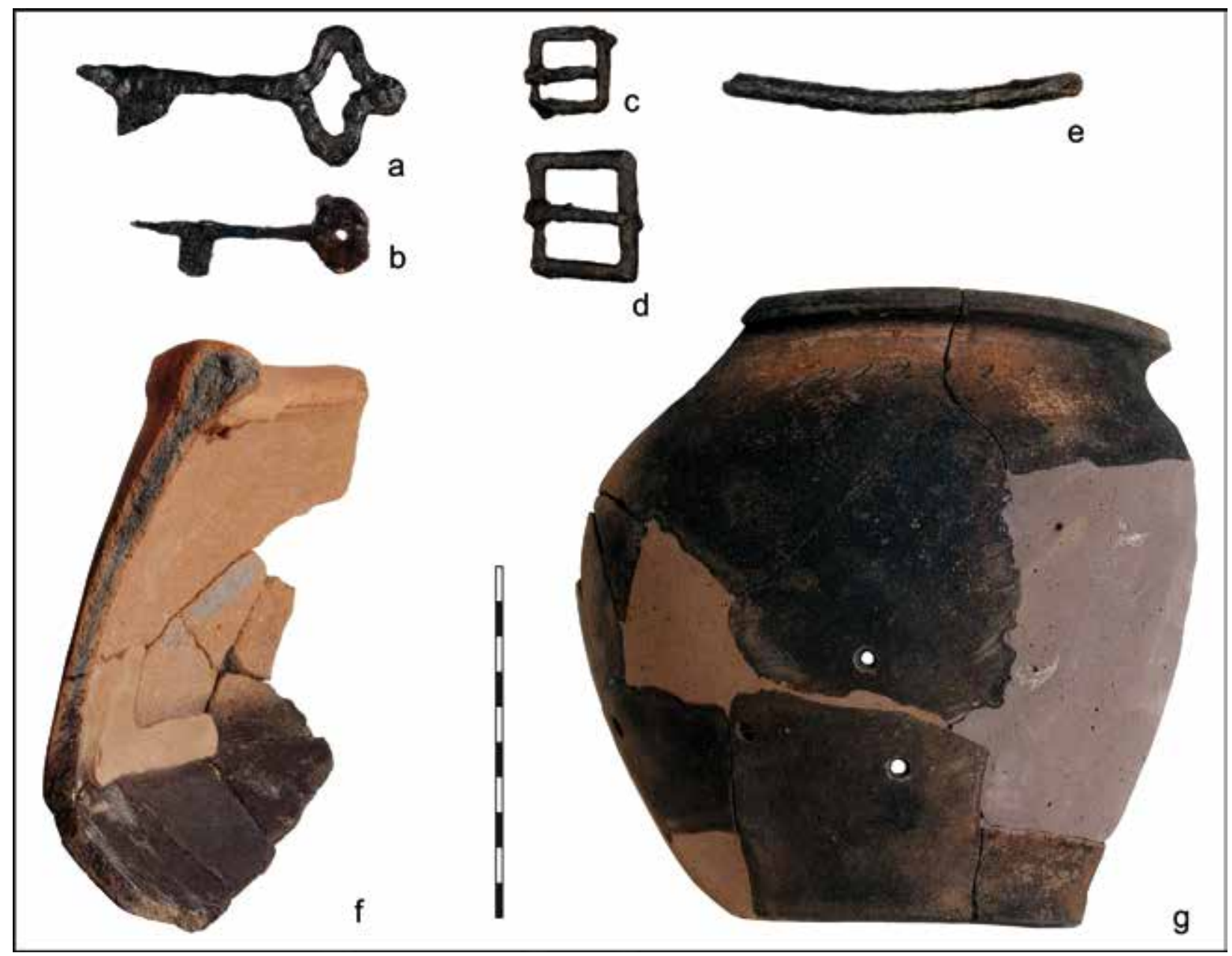

13. kép. Kiskunmajsa-Jonathermál-kelet. A 2. épület tárgyleletei. a: vaskulcs; b: vaskulcs; c: vascsat; d: vascsat; e: hengeres vashuzal; f: cserépbogrács töredéke; g: fazék töredéke

Fig. 13. Kiskunmajsa-Jonathermál-kelet. Finds from Building 2. a: iron key; b: iron key; c: iron buckle; d: iron buckle; e: cylindrical iron wire; f: fragment of a clay cauldron; g: fragment of a cooking pot

forrasztással rögzítették a mára már hiányzó gyúrüfejet. A pánt két szélén filigrándrótból kialakított kalászmintaszerú dísz fut körbe (12. kép d).

Érmék. Összesen 36 darab pénzérme és néhány töredék volt az épület középső részében egy kb. 1 méter átmérójü területen. Bizonyosan elmozgatott helyzetükból kifolyólag csak valószínúsíthető, hogy egykoron együtt voltak, feltételesen nevezhetjük az együttest éremleletnek. Az viszont kétségtelen, hogy a 2. épület betöltésében voltak, így fontos hangsúlyozni, hogy mindenképp az épülethez tartozó zárt leletegyüttest alkotnak.

Kulcs. Háromszögtaréjos, hajlított rombusz füllel, tömör szárú, 9,3 cm hosszú kovácsolt vaskulcs. A szár négyzet átmetszetú, a taréjon kissé túlfut. Méretében és kialakításában teljesen megegyezik a szanki épületben talált példánnyal. ${ }^{23}$

\footnotetext{
23 Wilhelm 2014, 85, 89.
}

Nagyobb láda, esetleg ajtó kulcsa lehetett (13. kép a).

Kulcs. Egyszerú négyszögtaréjos, tömör szárú, $7 \mathrm{~cm}$ hosszú, kisméretú vaskulcs. Az elvékonyodó szár jelentôsen túlfut a taréjon. A füle laposra kovácsolt, ovális forma, közepén kis kerek lyukkal áttört. A kulcs vékony, finomabb kivitelú, leginkább egy ládika kulcsa lehetett (13. kép b).

Vascsat. Négyzet alakú $(2,3 \mathrm{~cm} \times 2,3 \mathrm{~cm})$, egyszerü, kovácsolt vascsat. A csatpecek kissé elvékonyodó, enyhén hajlított. Az egyik áldozat ruházatához tartozhatott (13. kép c).

Vascsat. Téglalap alakú $(3 \times 3,5 \mathrm{~cm})$, egyszerú, kovácsolt vascsat. Lapított, téglalap átmetszetú a csattest, a pecket tartó szára vékonyabb a többinél. Az egyik áldozat ruházatához tartozhatott (13. kép d).

Vaspecek. Hengeres, kerek átmetszetú, $3 \mathrm{~cm}$ hosszú, töredékes vastárgy. Felületén erősen le- 
kopva csigavonalban vékony vájat, díszítés fut végig. Rendeltetése ismeretlen.

Vashuzal. Hengeres, kerek átmetszetú, tömör, kalapált, $10 \mathrm{~cm}$ hosszú, kissé hajlított rudacska. Rendeltetése ismeretlen (13. kép e).

Kerámia. Egy homokkal soványított cserépbográcsnak egy kupacban lévő több összeillő darabja az első szántáscsík felső részében (2/1. jelenség). Egy bográcsnak közel a harmada jött össze a töredékekből, ehhez kevés, nem beilleszthető darab is tartozik. Nagyobbik részét valószínúleg elvitte a mélyszántás (13. kép f). Felül a betöltésben, az épület középső részén egy vonalban széthúzva egy vágott peremú fazék (2/4. jelenség) összeillő nagyobb darabjai voltak. A perem alatt, a kiszélesedó váll felett egy sorban körömbenyomkodással díszített edény egyharmad része összeilleszthető. Több egyéb darabja arra utal, hogy további részeit a szántás húzta el (11. kép g).

$\mathrm{Az}$ épület leletanyagához tartozik még egy őrlőkő nagyobb töredéke is.

\section{Következtetések}

A Kiskunmajsa-Jonathermál-kelet lelóhelyen tapasztaltak egy nagymértékben roncsolt helyszín jelenségei, a belőlük levonható következtetések viszont kifejezetten messzire mutatnak.

$\mathrm{Az}$ előzőekben leírt rendellenes jelenségeket egy Árpád-kori település objektumai tartalmazták. A 2. felületen a korszakot tekintve hagyományos, közepes méretú, földbe mélyített épületet sikerült feltárni. Bár a mélyszántás az 1 . felületen szinte teljesen elpusztította azt a földbe mélyített objektumot, amelyben az emberi maradványokat megtaláltuk, az ott tapasztalt helyzet - az anatómiai rendben lévő vázrészek egyező szintje, azok nagyobb felületet érintő szóródása, illetve a kemence megléte, ami az emberi maradványokkal egy mélységben bizonyosan padlóra volt építve - azt támasztja alá, hogy egy az előzőhöz hasonló épület, minden bizonnyal ház helyét rekonstruálhatjuk. Az épületeken belül számtalan embercsont volt, sok esetben erősen átégve. A padlószinteken heverő vázrészek között egyértelmúen anatómiai rendben, ám rendellenes pózban elhelyezkedóket is lehetett azonosítani. Mivel az emberi maradványok egymástól nagy távolságra (115 m) kerültek elő, kizárhatjuk azt a lehetőséget, hogy egy szétszántott temetó maradványai lennének. A vázrészletek tájolása szintén ellentmond egy ilyen értelmezésnek. Az emberi maradványok kétségtelenül a földbe mélyített objektumokban voltak.

Az antropológiai elemzés meghatározta a minimum egyedszámot, eszerint az 1. épületben egy csecsemő/magzat, hét gyermek és öt felnőtt nó maradványai voltak, vagyis legkevesebb 13 egyén több-kevesebb csontja. Ezek közül három felnőtt és a csecsemő/magzat anatómiai rendben lévő vázrészei a padló mélységében hevertek, így már a feltárás folyamán is értelmezhetớk voltak. A 2. felszín épületében minimum hét gyermek, három fiatal és nyolc felnőtt nő maradványai mellett egy fiatal és két felnőtt férfi, vagyis legkevesebb 21 egyén roncsolt részletét különítette el az antropológiai elemzés. Közülük 11 jelenségben értelmezhető, bizonyosan anatómiai rendben lévő emberi vázrészletek voltak, melyek többségükben a padlón feküdtek. Az aprólékos antropológiai vizsgálat szerint az 1 . épületben több egyén csontjain is a halál beálltakor, illetve ahhoz idóben nagyon közel keletkezett (perimortem) erőszakos beavatkozás nyomait lehetett megfigyelni. A 2. épület nagyobb egyedszáma mellett sem azonosíthatók ember által okozott sérülések, ellenben egy felnőtt nő sípcsontján a halál bekövetkezte utáni (postmortem) állati rágásnyomok mutatkoztak. A 2. épületben a vázrészletek elhelyezkedése azt valószínúsíti, hogy csak az épület ÉNy-i felébe voltak bezsúfolva a holttestek. A másik oldalon a padlón heverő egyetlen láb arra utal, hogy nem a szántás pusztításából eredeztethetó a vázak hiánya, gyaníthatóan eleve sem épen kerültek az egyének a megtalálási pozíciójukba. Ez a 2/14. és 2/15. vázak egymáshoz viszonyított helyzete esetében a leginkább feltúnő. Nagyobb vázrészek vannak anatómiai rendben, de ezzel együtt mégis olyan módon, ami csak azzal magyarázható, hogy a testeket nem sértetlen állapotban helyezték a padlóra. Nem csonkolásról, inkább a már félig oszlásban lévő tetemek áthelyezéséről lehet szó. Ez az események után később, akár egy tereprendezés során is bekövetkezhetett, amikor a szerteszét heverő vázakat összegyújiötték, aztán rájuk gyújtották a romos épületeket. A történet fenti rekonstrukcióját erósíti az a megfigyelés, hogy néhány koponyatöredék belsó felületén is van komolyabb égésnyom, vagyis azok már nem voltak egészben az égetés pillanatában sem.

$\mathrm{Az}$ ásatás során előkerült valamennyi pénzérme - melyek valószínúleg két éremlelethez tartoztak - a tatárjáráshoz köthető éremkincsek horizontjába sorolható. Az ékszerek és viseleti elemek, az épület felszereléséhez tartozó tárgyak szintén gyakori összetevői a tatárjáráshoz kapcsolt leletegyütteseknek. Az objektumokban lévő két-két kerámiaedényt a szántás törte össze és mozgatta el, azt megelőzően valószínúleg egyben voltak, és a házak felszereléséhez tartoztak. Az épületek belső berendezése az eke által oko- 
zott nagyfokú roncsolás miatt nemigen rekonstruálható, mindamellett a valószínúsíthetően egész edények, a láda- vagy ajtóvasalások, az őrlókőtöredék, a ládakulcs mind arra mutatnak, hogy a berendezés egy része a pusztulás pillanatában az épületekben volt.

A mélyszántás okozta bolygatás ellenére is vitán felül áll, hogy két objektum zárt leletegyütteseit hoztuk felszínre. A betöltésekből előkerült tárgyak alkalmasak a pontos kormeghatározásra, emellett egymást is tökéletesen keltezik.

A Kiskunmajsán tapasztalt jelenségek szoros egyezést mutatnak az alig 8,5 km-re fekvő, Wilhelm Gábor vezette, Szank-Haladás Tsz melletti feltárás eredményeivel, ahol egy leégett épületen belül a kiskunmajsai számmal megegyezően szintén minimum 34 ember, 17 gyerek és 17 nó maradványait lehetett elkülöníteni. A Szankon megtalált tárgyak típusai - az ottani unikális aranyleletektől eltekintve - nagyobbrészt a Kiskunmajsán előkerültekkel azonosak. A vázmaradványok nagy többségükben ott sem voltak anatómiai rendben, ezt az ásató régész egy postmortem történt rendezéssel, átkutatással magyarázta. ${ }^{24} \mathrm{Az}$, hogy Kiskunmajsán a mélyszántás által érintetlenül hagyott részeken sem voltak teljes épségben a vázak, sőt több esetben e bolygatatlan sávokban is teljesen töredékesek voltak a csontok, szintén egy későbbi, utólagos beavatkozásra mutat.

A kiskunmajsai lelóhely K-i oldalán végigfutó hosszanti vizenyős rész partján, a helyszíntől mintegy 1,4 km-re DK-i irányban van a Kőkúti dúlő lelőhely. Itt egy kisebb domb tetején lévő Árpád-kori templomról és a körülötte fekvő temetőről már korábban is voltak ismereteink. A most feltárt épületek minden bizonnyal az e templom környezetében szerveződött, szórt szerkezetú Árpád-kori településhez tartoztak.

A fentiekben vázolt tények azt bizonyítják, hogy a Kiskunmajsa határában történt pusztítást az 1241-1242. évi tatárjárás eseményeihez kell kapcsolnunk.

\section{Bugac-Felsőmonostor-Csitári tanya lelőhely (Pétermonostora)}

A kiskunmajsai leletmentést követő héten, 2016. április 4-én indítottuk el a kecskeméti múzeum tervásatását a bugaci Pétermonostorán. ${ }^{25}$ Elsődleges cél volt, hogy a viszonylag jól ismert kolos-

24 WILHELM 2014

25 A feltárás 2016. április 4.-július 8. között zajlott. Hálás köszönetünket fejezzük ki a földtulajdonosnak, Csitári Tibornak, aki engedélyezte a feltárási munkálatokat. toregyüttestól távolabbi részeken, a környező településen történjen kutatás, és meg lehessen vizsgálni az Árpád-kori nagy központ és a késő középkori falu átalakulásának folyamatát. A tervek végül csak részben teljesültek, mivel a település késő középkori periódusához tartozó jelenségek a feltárt felületeken végül egyáltalán nem kerültek elő, viszont az Árpád-kori településről kiemelkedő adatokat sikerült begyújteni. Ráadásul a település utolsó fázisához kapcsolódva olyan jelenségek mutatkoztak, melyek korábbi sejtéseket tettek bizonyossá a település pusztulását illetően.

Három évadon keresztül, 2010 és 2013 között folytak ásatások a Bugac nagyközség melletti Felsőmonostor határrészben, a Csitári tanya mellett. A 12. század közepén alapított nemzetségi monostor egykori nevén, Pétermonostoraként került be a szakmai köztudatba. Az éveken keresztül folytatott szisztematikus kutatások egy addig ismeretlen kolostort és az azt körülöleló, a korszakban kifejezetten nagynak mondható település részleteit hozták felszínre. Korábbi tanulmányomban a lelóhely jellegzetességeinek ismertetése, a környezet vizsgálata, aprólékos elemzése révén sikerült arra a következtetésre jutni, hogy a Homokhátságon egykor vezető szerepet betöltő egyházi és kereskedelmi központ pusztulását a tatárjáráshoz kell kötnünk. A végkövetkeztetéshez vezetó érvek ismertetése akkor megtörtént, így jelen tanulmányban nincs ok ezek megismétlésére. ${ }^{26}$ Emlékeztetőül azonban érdemes röviden összefoglalni a fóbb indokokat.

Közvetett bizonyítékok sora mutatja, hogy Pétermonostora életében a 13. század közepén nagy változás, pontosabban törés figyelhető meg. Szembetúnő a település kiterjedésének a csökkenése, illetve településszerkezetének gyökeres megváltozása. A nagy kiterjedésú, mostani ismereteink szerint $2 \times 1,2 \mathrm{~km}$ alapterületü, kiemelkedő és intenzív leletanyagot nyújtó Árpád-kori településsel szemben egy jóval kisebb területú, egy utca mentén szervezett, a környéken átlagosnak számító méretú és intenzitású falu létesült a 14. század közepén. A mára már régészeti eredményekkel is alátámasztott települési struktúrák is nagymértékben különböznek, elég csak a központi elemet jelentő kolostor és a 14. századi kisméretú plébániatemplom különbözőségére utalni. De az új kutatások szerint az egyéb Árpádkori épülettípusok is kiemelik a helyszínt az egykori falusias települések köréből. ${ }^{27}$ A lelőhely

26 Rosta 2014

27 12-13. századi pincék, nagy raktárépületek, melléképületek, földfelszíni, kő és tégla építőanyag felhasználásával készült épületek mellett „hagyományos”, Árpád-kori földbe mélyí- 
területéről a szisztematikus múszeres leletfelderítéssel bekerült több mint ezer pénzérme bizonysága szerint az 1250-es és az 1340-es évek között errefelé semmilyen pénzforgalmat nem lehet kimutatni. A fenti jegyek alapján megkockáztatható, hogy nem is egy település átalakulását kell vizsgálni, hanem két, egymáshoz mindössze térben kapcsolódó településról van szó a lelőhelyen. A közvetett bizonyítékok sorába illeszkedik a kolostor temetőjének 13. századi teljes felhagyása, a kolostor épületének 13. század végi, 14. század eleji lebontása, majd attól 70 méterre egy kis templom és a mellette kialakuló temetó létesítése az 1340-es években. A Pétermonostora tágabb környezetében megtalált nagyszámú, az Árpád-korban fennállott templomos település megszúnése, továbbá a szomszédban, Szankon és Kiskunmajsán a tatárjárás pusztításának kétséget kizáróan megtalált nyomai mind arra mutatnak, hogy maga a terület nagyfokú pusztulást szenvedett a 13. század közepén.

A fentiek mellett eddig is rendelkezésünkre állt néhány közvetlen bizonyíték, melyek pusztításra engedtek következtetni. Két komolyabb 13. századi vasdepólelet is előkerült a település különböző pontjain, melyekben ekevasak és csoroszlyák voltak egymásra helyezve. A 2012. évi feltárás során a keleti szárnyban a kolostor bontási törmeléke alatt - sajnos éppen az újabb kori földhordások által leginkább roncsolt részen - találtuk meg két fiatal és egy felnőtt egyén rendellenes pózban fekvő vázait, illetve vázrészét. ${ }^{28}$ A késóbbi nagyfokú bolygatás okozta bizonytalan rétegtani eredmények nem engedték kétséget kizáróan a végső pusztuláshoz kötni ezeket a jelenségeket, még ha a terület egyéb vonatkozásai erre okot is adhattak volna. A 2016. évi feltárás azonban e jelenség megítélésében is döntő fordulatot hozott.

\section{A 2016. évi feltárás}

A felszíni leletanyag-szóródás - különösen a korábbi terepi kutatások során GPS koordinátákkal bemért fémanyag helyzete - alapján jelöltük ki a feltárandó felületeket. A két korszak települései változásának megfigyelése érdekében a kolostortól távolabb, attól keleti irányban lévő nagy kiterjedésú szántóföld vizsgálata mellett döntöttünk (14. kép). Feltárásunkat három nagyobb felületen terveztük, melyból végül kettő szolgáltatott ki-

\footnotetext{
tett ház nem is került elő a 2016. évi feltárás során. Az Árpádkori épületek és egyéb telepobjektumok a kolostoregyüttestől közel 200 méterre az épülethez vannak tájolva, felvetve ezzel akár egy tervezett települési struktúra lehetőségét is. 28 Rosta 2014, 226, 228.
}

emelkedő információkat a település életéról. A kolostor épületétől mintegy 150 méterre lévő kisebb dombvonulat tetején mindkét időszak, míg keleti lábánál már egyértelmúen csak az Árpád-kor telepjelenségeit lehetett előzetesen sejteni. Két nagyobb felületünket is ennek megfelelöen nyitottuk meg a 2016-ban szerencsére éppen parlagon hagyott részen. Egyértelmúen kiderült, hogy a dombhát tetején, a felszínen elszóródott késő középkori leletanyag ellenére a korszakba egy bizonytalan rendeltetésú gödrön kívül semmilyen települési objektum nem sorolható. Úgy tünik, hogy a középkori út mentén sorakozó házakhoz kapcsolódó hátsó kertek és belső szántók nyúltak csak idáig, némi felszíni leletanyagot szolgáltatva. A területhasználat változása miatt a későbbi időszak telepobjektumai ilyen formán nem roncsolták a pusztuláshoz köthető korábbi jelenségeket.

A számunkra kiemelten fontos jelenségek a $404 \mathrm{~m}^{2}$ nagyságú 1 . felületen, a dombvonulat keleti lábánál kerültek elő. A felső, szántott réteg eltávolítására gépi erőt vettünk igénybe, ez utóbb jelentős hibának bizonyult. A szántás eltávolítását a dombvonulat tetején, a $388 \mathrm{~m}^{2}$ nagyságú 2 . felületen kezdtük, ahol erősen váltakozó rétegsorral találtuk magunkat szembe. A Kiskunság jellegzetességének megfelelően geológiai és antropogén rétegződések váltották egymást. A dombtetőn a mai, mintegy 50-60 cm mélységú szántás alatt nagyobbrészt újabb kori lepelhomok volt változó vastagságban, máshol ez hiányzott, és a korábbi, kő- és téglatörmelékkel kevert, humuszos anyagú réteg bukkant egyből felszínre. Mivel ezen a kevert, sötét felületen nem volt érzékelhető semmilyen beásás, így ezt a kb. 20-40 cm vastag kultúrréteget állandó fémkeresőzés mellett szintén gépi eróvel távolítottuk el. Az ez alatt fekvő, a szarmata objektumokat elfedő barna homokréteg tetején lehetett először észlelni Árpád-kori telepjelenségeket. E barna lepelhomok alatt húzódott az érintetlen ôshumusz, illetve még lejjebb természetesen a sárga homok altalaj (15. kép). Az objektumok többsége nem is ért le az altalajig, leginkább az antropogén és a homokrétegekból bontottuk ki őket. Maguk az azonosított rétegek is erősen váltakozó vastagságban jelentkeztek, néhol 50-60 cm, néhány méterrel odébb már 1,5 m földet kellett eltávolítani, míg értelmezhető települési jelenségek bukkantak felszínre. Sajnálatos módon éppen az első gépi ráhúzás - még jelentősen az altalaj és az őshumusz felett - emberi vázakat roncsolt meg, melyeknek ilyen magas elhelyezkedésére nem lehetett számítani. A gépi roncsolás mellett némelyik váz esetében az sem kizárható, hogy már a 


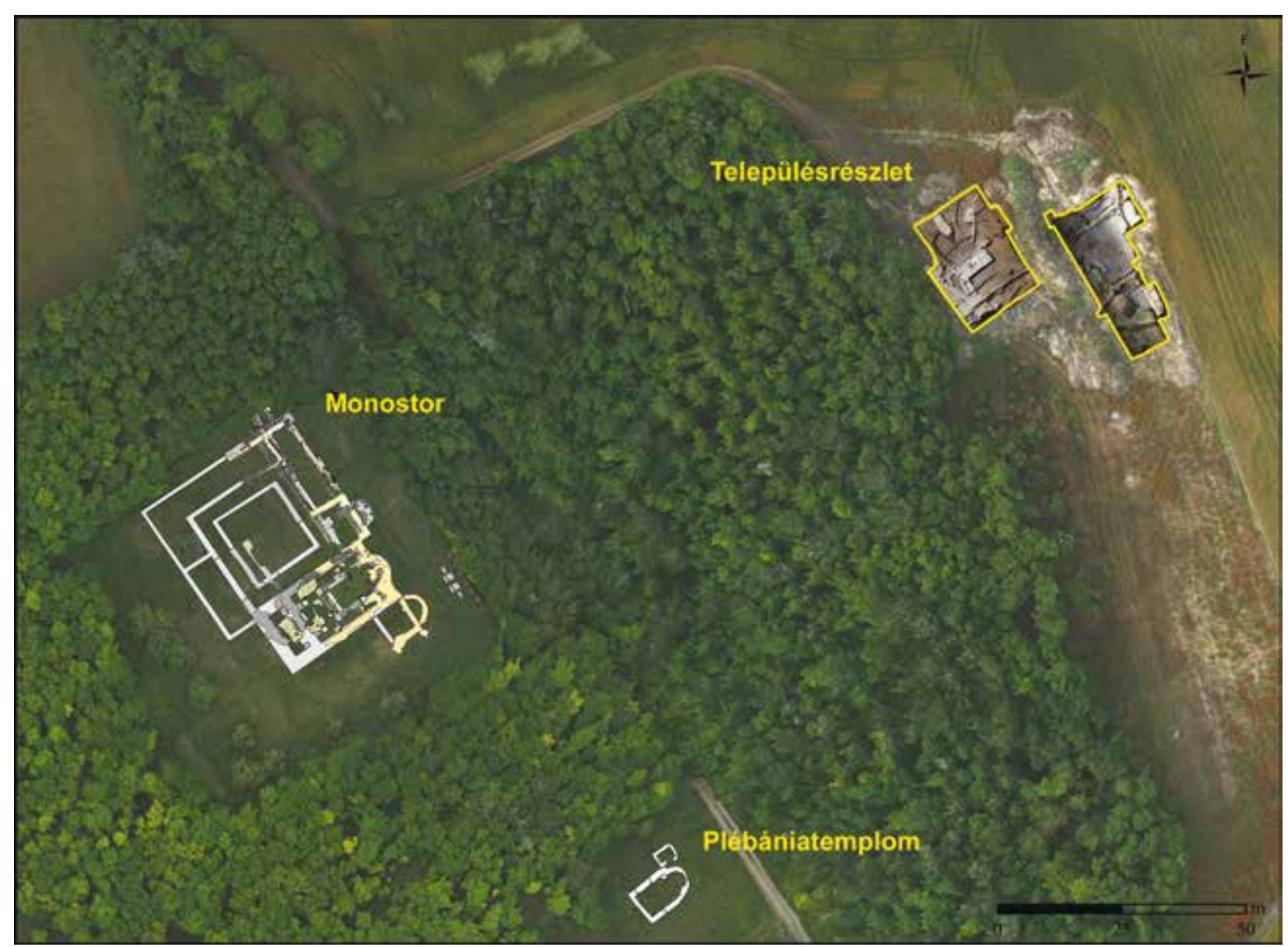

14. kép. Bugac-Felsőmonostor (Pétermonostora). A kolostoregyüttes és a 2016. évi feltárás egymáshoz viszonyított helyzete Fig. 14. Bugac-Felsőmonostor (Pétermonostora). The monastery and the location of the 2016 excavation campaign

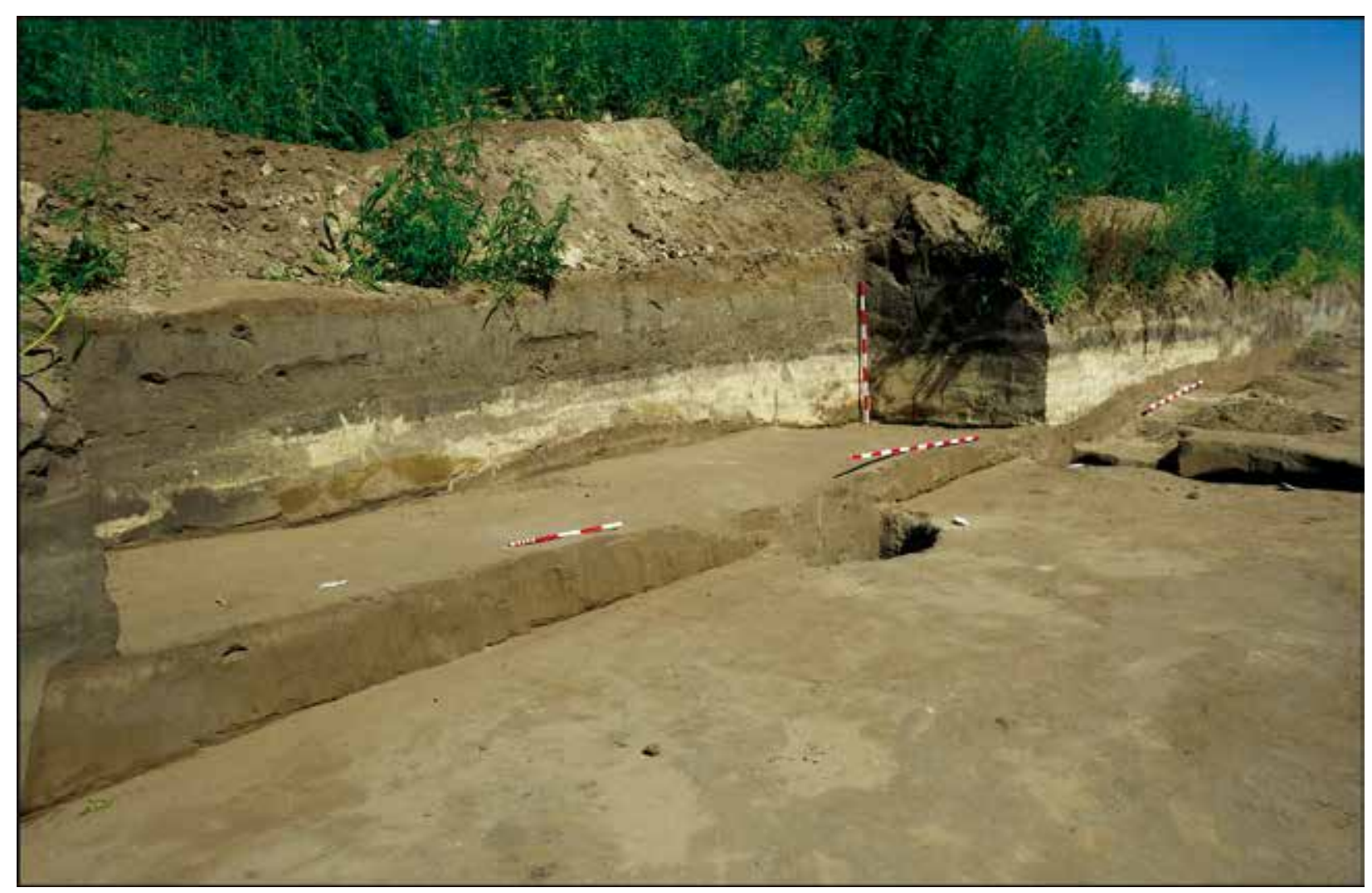

15. kép. Bugac-Felsőmonostor. Antropogén és lepelhomokrétegek a feltárás területén

Fig. 15. Bugac-Felsőmonostor. Anthropogenic and sand sheet layers in the excavated area 
szántás mélysége is elérte őket, de a rongálásban játszott szerepünk, felelősségünk vitathatatlan. Mindettől függetlenül a jelenségek értelmezését a roncsolódás ellenére is megkísérelhetjük, de kétségtelenül még több eredményt lehetett volna felmutatni, ha érintetlen vázakkal dolgozhattunk volna.

A megközelítőleg egy vonalban, de egymástól változó távolságra rendezetlenül fekvő hat emberi maradványon kívül az árkok felső betöltési rétegéből előkerült állatok anatómiai rendben lévő vázai, valamint a település kései fázisához tartozó objektumoknak az égése, pusztulása az a horizont, mely a település végét jelzi. Mivel éppen a kritikus jelenségekhez nem kapcsolódnak pontos korhatározásra alkalmas pénzek, így a pusztulási horizont tatárjáráshoz kötése csak a körülmények gondos mérlegelése nyomán lehetséges.

\section{Emberi maradványok}

1. váz. A humusz eltávolítása során a munkagép által a medencerész alatt részben elpusztított felnőtt váza. A fiatal nő a jobb oldalán fekszik, a jobb alkarja felhajlítva az állig, a bal behajlítva, a testen keresztül kézfejével a jobb felkar közepét fogja. A kiengedett jobb kézfej mellett közvetlenül egy bronztárgy feküdt, mely egy rövid, háromszög átmetszetú tőr tokjának díszítéseként határozható meg. A hozzá tartozó fegyver nem került elő. A nő egyik térde az eredeti helyzetében megmaradt combcsontrészlet szerint a jobb könyékig bizonyosan fel volt húzva, s ez a 4. vázhoz hasonló zsugorított pozícióra enged következtetni. A jobb alkarcsontokon egy régebbi, már gyógyult törés van. A test egy korábban feltöltődött, mély, méhkas alakú verem tetején feküdt, elkülönülve a 2-5. vázak alkotta csoporttól (16. kép).

2. váz. Gyermek csaknem ép, nyújtott váza. A koponyája jobbra, kissé előrebillent. A bal kézfej a medencében pihen, a jobb kar kissé eltartva a testtől. Az egyenesen kinyújtott lábak a lábfej irányában emelkednek, a test felső részénél magasabban helyezkednek el (16. kép).

3. váz. Kisgyermek váza, ami a 4., zsugorított helyzetú vázon fekszik. A koponyája hiányzik, ennek oka a gépi humuszolásban is kereshető, ami a két, magasabban elhelyezkedő térdet is érintette. A bal kar kissé eltart a testtől, a térdek enyhén megemelkedtek, amit az alatta lévő 4. váz combjának helyzete eredményezett. A két előkerült emberi maradvány közvetlenül egymás fölött helyezkedik el, a két test földbe kerülése kétségtelenül egyszerre történt (16., 25. kép).
4. váz. Gyermek szintén rendellenes pózban fekvő váza. A felsőtest háton fekvő, nyújtott helyzetú. A jobb alkar teljesen fel van húzva a jobb vállhoz. A bal alkar keresztben a hason, kézfeje erősen kifordulva. A jobb láb térdben behajlítva, erősen fel van húzva a jobb könyékig, a lábfej szinte a medencénél van. A bal comb is fel van húzva 90 fokos szögben a felsőtesthez képest. A 3. kisgyereket a helyzete alapján egyszerúen rálökték a zsugorított pózban lévőre (16., 25. kép).

5. váz. A gépi humuszolás által legjobban roncsolt, szinte elpusztított fiatal egyén váza. A medence és a lábak maradtak anatómiai rendben, eszerint a lábak nyújtottak voltak, a jobb kézfej a medencében volt. A test felsőbb részének fekvéséről nincs információnk, a bordasor másodlagos helyzetben (16. kép).

6. váz. Kisgyerek váza elkülönülve a többi váztól. A magas fekvéséból ítélve a szántás is okozhatott benne roncsolást. A lábak épek, nyújtottak. A felsőtestből a jobb kar, a csigolyasor alsó része és néhány borda volt eredeti helyzetében. A megmaradt csontok anatómiai rendben vannak, így megállapítható, hogy a felsőtest egy kissé kicsavart helyzetben volt. A kisgyermek teste a három pénzzel is a 12. század közepére keltezett, teljesen feltöltődött pincehelyiség (41. épület) betöltésének tetején feküdt (16. kép).

Az emberi vázak nem voltak a hagyományos értelemben véve eltemetve, esetükben sírokról semmiképpen sem beszélhetünk. A maradványok közege megegyezik az Árpád-kori kultúrréteggel, azaz kő- és téglatörmelék, továbbá némi kerámia és állatcsont is volt a vázak között. Két esetben bizonyosan korábbi, lényegében teljesen feltöltődött Árpád-kori (12. századi) telepobjektumok felső betöltésén feküdtek, azokat felülrétegezték. Mindez együtt egyértelmúvé teszi azt is, hogy földbe kerülésük biztosan nem történhetett az Árpád-kornál korábbi időben. Az értelmezhető vázak közül legalább négy mindenképpen rendellenes pózban feküdt, különösen a korabeli temetkezési szokásokat tekintve. Fontos, hogy mindegyik egyén más helyzetben volt, a két váz felhúzott lábaitól és a testek irányultságától eltekintve nincs hasonlóság a fekvések között. Mindössze egyetlen fiatal nem tekinthető első ránézésre kirívónak, de a környezet kapcsán nem kétséges, hogy ő is illeszkedik a többihez. A vázak elhelyezkedése részben rendezettséget mutat, legalábbis 3+1 váz egy csoportban, egymástól megközelítőleg egyező távolságra, egy irányítással sorban fekszik. Két másik váz azonban e csoporttól elkülönülten, bár szintén nagyjából egy tájolással jelentkezik. A tanulmány összefog- 


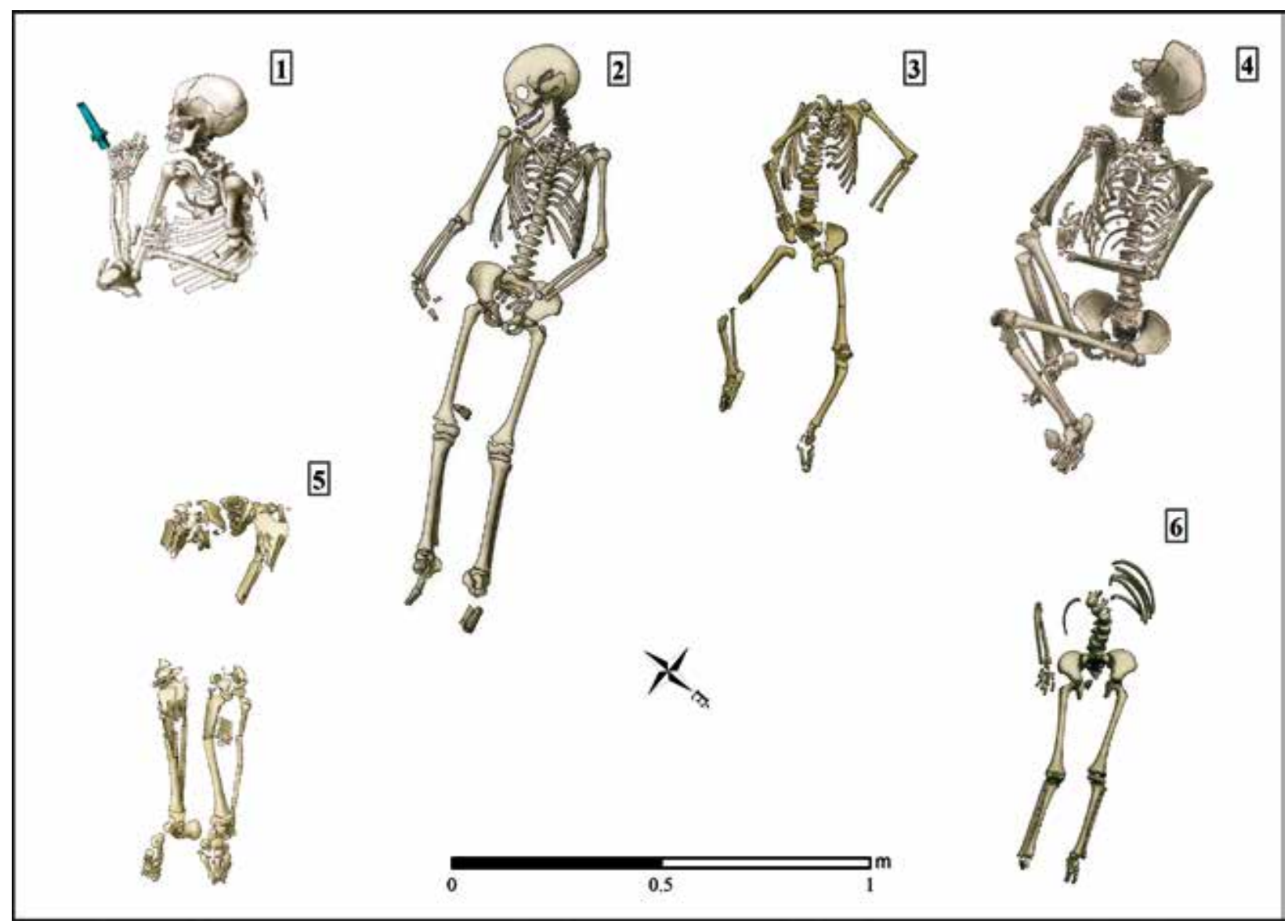

16. kép. Bugac-Felsőmonostor. A 2016. évben feltárt emberi vázak

Fig. 16. Bugac-Felsőmonostor. Human skeletons uncovered in 2016

laló részében még bővebben ki lesz fejtve, de itt is meg kell említeni, hogy a két erősen felhúzott lábú egyén a helyszíni antropológiai értelmezés szerint ülő vagy guggoló pozícióból került a feltáráskor észlelt helyzetébe. ${ }^{29} \mathrm{Az}$ elhunytak kor szerinti eloszlása is mindenképpen figyelemre méltó, hiszen öt gyermek és egy fiatal nó alkotja a csoportot. Az elhunytakhoz a csontok közé keveredett Árpád-kori kerámiatöredékeken kívül mindössze egyetlen értelmezhető tárgy, az 1. váz keze melletti tőrhüvely-boritólemez köthetó.

\section{Állati maradványok}

15. váz. Egy keskeny árokba belehajított kutya anatómiai rendben fekvő váza. A 14. árok felső betöltésében feküdt, az árok nagyrészt már fel volt töltődve a váz odakerülésekor. A kutya alsó állkapcsa kissé elmozdult, de a váz többi része rendezett helyzetben volt. A kutya koponyáján egyértelmú, perimortem sérülések vannak, me-

29 Bernert Zsolt antropológus a helyszínen eredeti helyzetükben is szemrevételezte az emberi vázakat, akárcsak Csippán Péter archeozoológus az állati maradványokat. lyek részint vágó-, részint ütőfegyverektől, -eszközöktől származnak. Az egyetlen olyan állati maradványunk, mely biztosan a pusztulási horizonthoz köthetó, és nem a 31. árokban feküdt.

30. vázrészlet. Ép lókoponya és hozzá tartozó három nyakcsigolya a 31. árok betöltésének legfelső rétegében, annak szélénél az Árpád-kori kultúrrétegben. A szelvény szélénél feküdt, ezért rányitottunk, de a váz a közelben biztosan nem folytatódott. A rábontás során került elő alóla az árok betöltésébe beleásva egy ép kézimérlegegyüttes. Bár a csigolyákon bontott állapotban nem látszott idegenkezűség nyoma, ilyen formán mégsem nevezhető általános jelenségnek egy ló anatómiai rendben fekvő feje és nyakrésze.

42. vázrészlet. Borjú csigolyasora anatómiai rendben a 31. árok D-i oldalában, a szelvény szélében. A kisebb rábontás szerint közvetlenül mellette nem folytatódott egyéb vázrésszel. Kissé mélyebben fekszik, mint a horizonthoz tartozó többi állati maradvány, de a 31. árok betöltési rétegei az árok a D-i oldala felé lejtettek jelezve, hogy az ároknak legalábbis ez a szakasza kevésbé volt betöltődve a pusztulás pillanatában. 
43. váz. Macska anatómiai rendben fekvő váza. A 6. kisgyermek vázához hasonlóan a 41. épület pincehelyiségének teljesen feltöltódött területén, de már egyértelmúen a 31. árok nyomvonalában volt. Az árok legfelső betöltési rétegében a környezetében lévő további maradványokkal egy magasságban feküdt. Nem kétséges, hogy ez a tetem is a pusztulási horizontba tartozik.

44/1. váz. A 31. árok közepe táján két állati váz volt egymáson. A felső fiatal borjú teljes anatómiai rendben, a koponyája hiányzott. Az árok egyenetlen betöltődése miatt a nyaki része kissé mélyebben feküdt, mint az alatta lévő váz.

44/2. váz. A 44/1. kisborjúhoz hasonlóan teljes anatómiai rendben lévő újabb borjú váza, mindössze a koponya hiányzik. A két tetem egymásra meróleges helyzetben feküdt, és kétségtelenül egyszerre került abba az állapotba, amelyben megtaláltuk őket.

46. váz. A szelvényünk Ny-i irányú rábontása során előkerült kisborjú a 31. árok vonalában. A hiányzó alsó részt kivéve anatómiai rendben fekszik, a koponyája is megvan.

49. váz. A 46. váz mellett fekvő kisborjú maradványai. A csontok megközelítőleg anatómiai rendben vannak, a borjú koponyája hiányzik.

56. vázrészlet. Egy sertés részben anatómiai rendben lévő maradványai, melyek csak feltételesen kapcsolhatók a pusztulási horizonthoz. A 31. árok melletti, azzal párhuzamosan futó 32. árokban, annak egyik felsőbb betöltési rétegében feküdt. A sertés csigolyasora és a bordák egy része némi anatómiai rendet mutat, de az egyértelmúen a pusztuláshoz kapcsolható maradványokkal szemben nagyobb részei is hiányoznak.

Az állati maradványok szintén rendhagyó helyzetek kialakulásáról tanúskodnak a település életének a végén. A teljes anatómiai rendben lévő állatok tetemei önmagukban még nem jelentenének rendellenességet egyetlen régészeti korszak telepein sem, az itt megfigyelhetó jelenségek együttese azonban már semmiképpen sem nevezhető általánosnak.

A teljesen vagy nagyobbrészt anatómiai rendben lévő hét váz egy objektumnak, a 31. árok betöltésének felső részében szinte egy magasságban helyezkedett el. Az állatok elpusztulása között nincs okunk hosszabb vagy akár bármennyi időt is feltételezni. Mindenképpen figyelemre méltó, hogy a hét maradvány az árok mindössze 12 méteres feltárt szakaszán jelentkezik. A másik két váz szintén árkok felső betöltési szintjein helyezkedik el, besorolhatók e pusztulási horizontba. Az állati maradványok között-alatt nagy mennyiségú, az Árpád-kori kultúrréteghez tarto- zó teleplelet volt. A kis területre koncentrálódó nagy egyedszám mellett az állatok fajbeli eloszlása is érdekes. A pusztulási horizonthoz köthető öt borjú, egy ló, egy macska, illetve egy kutya és feltételesen egy sertés. A vizsgált maradványok további különlegessége, hogy valamennyi váz fiatal egyedé volt, a négy darab kisborjú pedig különösen kiemelkedik e sorból. Fiatal állatok ilyen szintú tömeges elhalása szintén rendellenesnek mondható. A fenti tények már önmagukban is egy sajátos állapotra utalnak, a különféle állatok egy eseményhez köthető elhullásával a pusztulási horizont kétségbevonhatatlan.

A megválaszolandó kérdés az, hogy ezt a pusztulási horizontot milyen eseményhez lehet kötni, és az állatok elhullása összekapcsolható-e az emberek elhalálozásával. A feltárt vázak fajbéli eloszlására tekintettel nemigen lehet valamiféle járvány számlájára írni a pusztulást, de ugyanilyen megfontolásból bárminemú mérgezésnek is kicsi a valószínúsége. Az éhhalál és a szomjúság következtében bekövetkező pusztulást ugyanígy kizárja a húsevő és növényevő (és mindenevő) állatok együttes elhalása. A legfontosabb érv bárminemú "természetes" eredetú pusztulással szemben a maradványok elhelyezkedése. Hiszen ha csak egy ilyen "természetes”, az állatokat érintő járvány vagy mérgezés okozta ezt a helyzetet, úgy nem kellett volna abban a helyzetben lenniük, ahogy megtaláltuk őket: ugyanis nem elásva, dögkútba dobva, hanem szerteszéjjel hevertek az egykori járószinten vagy legalábbis annak közvetlen közelében. Nemigen lehet olyan „normális” települési állapotot elképzelni, ahol ilyen módon az épületek, telepobjektumok között hagyták volna a lakosok az elhullott állatokat a felszínen (17. kép). Minden jel arra mutat, hogy a tragikus következményekkel járó események nem csak az állatokat érintették, hanem az embereket is, akiknek a tetemeket kellett volna eltakarítani.

A Pétermonostorán tapasztalt helyzet nem egyedülálló: a biztosan a tatárjáráshoz köthetó helyszínek közül több esetben az elhullott állatok és az emberi áldozatok maradványainak együttes előfordulása jelezte a pusztítást. Orosházán egy árokban az emberi vázak egy nagyjából egész ló és egy lókoponya mellett feküdtek. Ezt, mint ahogy a település különböző részein gödrökből és árkokból előkerült további összetartozó lóvázrészleteket, valamint néhány teljes kutyavázat a feltáró régészek szintén a falut ért támadással hozták összefüggésbe. ${ }^{30}$ Dunaföldváron három kutyatetem mellett egy ló vázrészeit

30 Gyucha-RózSA 2014, 60. 


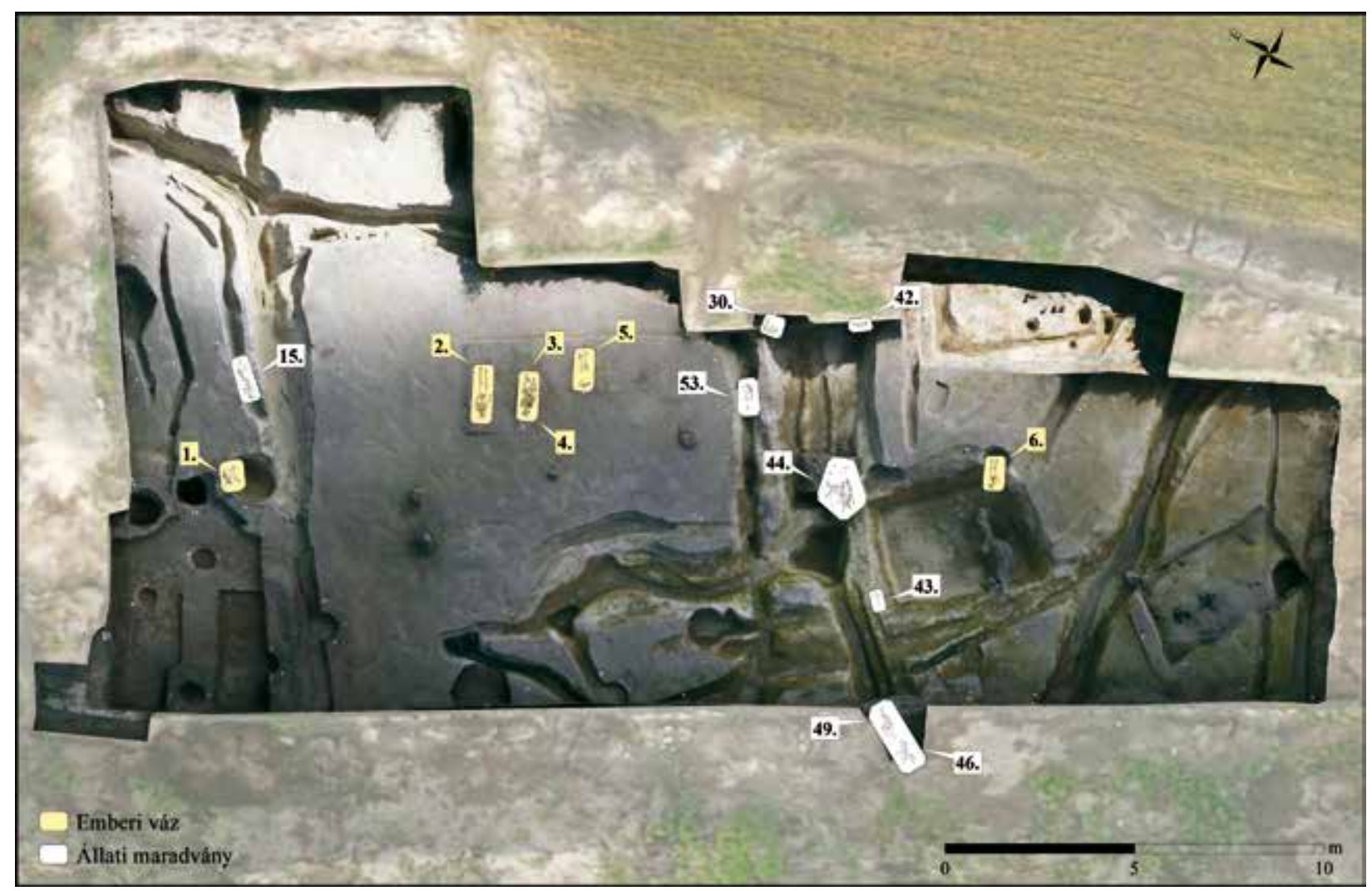

17. kép. Bugac-Felsőmonostor. Az egykori járószinten elszórtan fekvő emberi és állati vázak helyzete

Fig. 17. Bugac-Felsómonostor. Human and animal skeletons on the one-time occupation level

és emberi maradványt találtak egy kút belsejében. ${ }^{31}$ Hejőkeresztúron szintén több lóhoz tartozó maradvány volt egy gödörben, s ezek ugyanúgy összefüggésben lehetnek a település pusztulásával és az emberek elhalálozásával. ${ }^{32}$

A stratigráfiai bizonyítékok és egyéb fenti érvek alapján nemigen marad más lehetőség, mint hogy az emberek és az állatok pusztulását az analógiákhoz hasonlóan Pétermonostorán is összekapcsoljuk, és az állatok tömeges elhalását is az erószakos cselekményekhez kössük. A pusztulási horizonthoz tartozó kutya koponyáján ennek kétségtelen nyomait lehet felfedezni, még ha a többi maradványon nem is mutatkoznak ilyen egyértelmú jegyek.

\section{Objektumok}

7. épület. Földbe mélyített, $4 \times 2,5 \mathrm{~m}$ alapterületú, ÉNy-DK tájolású, teljesen leégett épület. Padlószintje vízszintes, alig letaposott, az épületben nem volt kemence. Az ÉNy-i rövidebb fal közép-

\footnotetext{
31 SZILÁGyi-Serlegi 2014, 130.

32 WOLF 2014, 72.
}

ső részén, a hosszanti tengelyben egy kisebb méretú cölöphely volt, ami a tetó alátámasztását szolgálta. Az épület betöltése tele volt faszénmaradványokkal, több helyen gerendák nagyobb darabjai is megmaradtak. Az oldalfal bontása közben szenült vékony gallyakat lehetett megfigyelni, és ez sövényfalra enged következtetni. Az épület D-i sarkában egy lekerekített sarkú, háromszög alapterületú, egyértelmúen az épület oldalához igazított, egyenes falú, mély gödör volt, ami nem egy korábbi telepjelenség, hanem az épülethez tartozott. Az épület padlóján nagy mennyiségú vastárgy, főként a tető összeállítására szolgáló szögek és kapcsok voltak elszórva. A sarokban elhelyezkedő gödör aljába két ép sarló volt szabályosan belehelyezve. Érdekesség, hogy a bontás pillanatában még látható volt teljesen szenült fanyelük is. Az épület három árokkal volt szuperpozíciós helyzetben, mindegyiket felülrétegezte. A kisméretú, földbe vájt épületet nem házként, hanem valamilyen melléképületként azonosíthatjuk (18. kép).

11. árok. A 7. épületnél korábbi, Ny-K irányú árok. Az épület E-i sarkában álló elszenesedett gerenda is egyértelmúen jelzi egymáshoz való viszonyukat. Az árok a település korábbi fázisához 


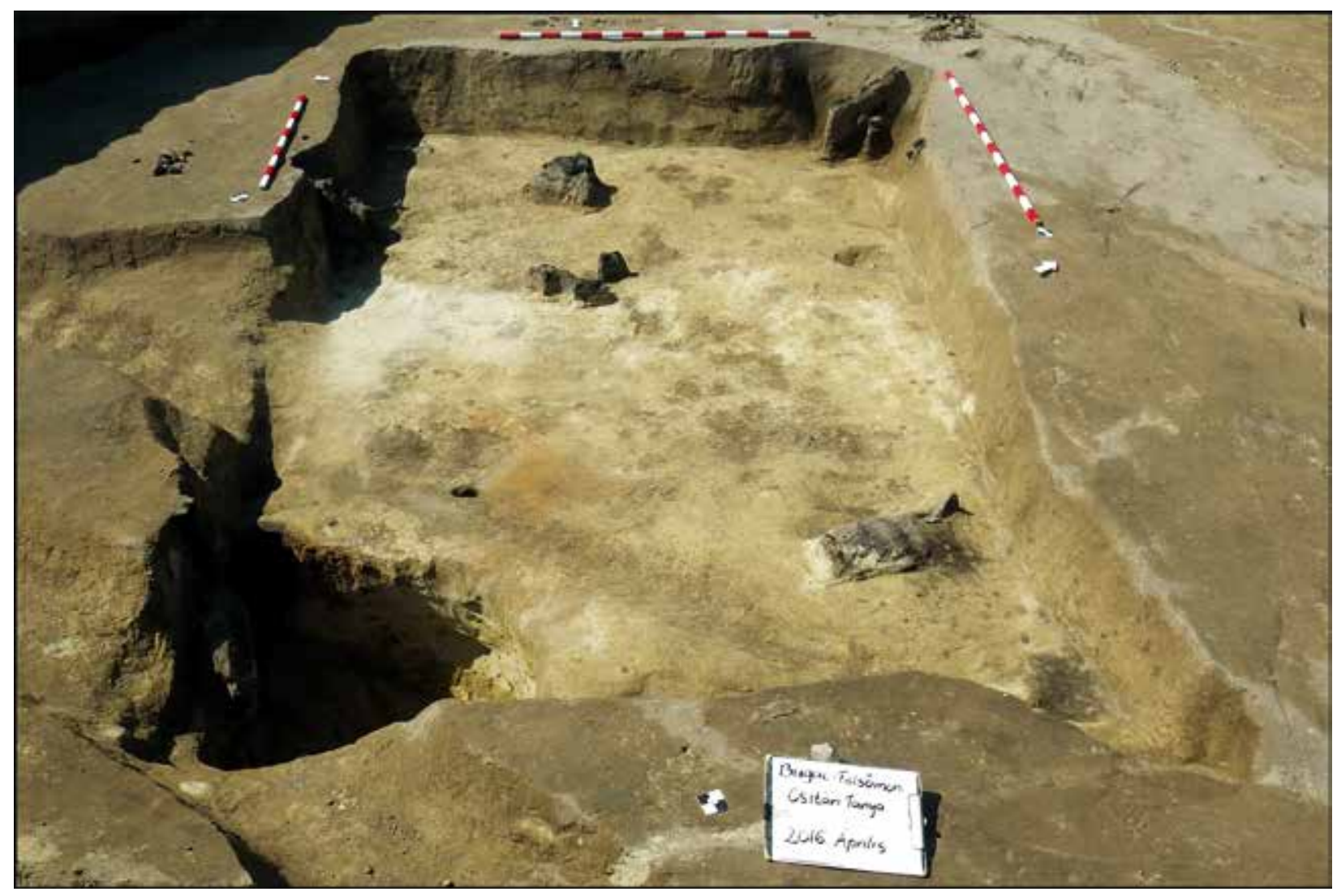

18. kép. Bugac-Felsómonostor. A 7. épület

Fig. 18. Bugac-Felsőmonostor. Building 7

sorolható objektum, a melléképület építésekor már nagyrészt fel volt töltődve. A betöltés felső rétegéból egy 12. század közepére keltezett anonim denár jött elő. Az épület mellett, az árok egyik felső betöltési szintjén vékony égési csík mutatkozik, ami az épület leégése pillanatában az ahhoz tartozó külsó járószintet jelöli. Ilyen formán az árok e rétege a pusztulási horizonthoz tartozik, a pusztulás környezetmodelljének megalkotásához ad segítséget.

14. árok. A nagy, ÉNy-DK irányítású telekkerító árokrendszerhez kapcsolódó keskeny mellékárok. A 15. kutya váza a nyesési szintünkön jelentkezett, mintegy $60 \mathrm{~cm}$-rel magasabban, mint az árok alja. Ezek szerint a kutya tetemének odakerülésekor az árok nagyrészt már fel volt töltődve. A kutyaváz fekvésének magassága a pusztulás idejének megsüllyedt járószintjét mutatja.

31. árok. Többszörösen megúiított széles, ÉKDNy irányú árok. Mintegy 12 m hosszú szakasza esett a feltárt területbe. Az irányítása tökéletesen illeszkedik a település alapvető struktúrájába, vagyis az épületek és árkok által is meghatározott, ÉNy-DK irányú rendszerbe. Nem mellesleg a települési részlet feltárása szerint a települési struktúra és kolostorépület tájolása között is tö- kéletes összhang mutatkozik. Az árok általunk megfigyelt legfelső betöltésében, megközelítőleg az altalaj mélységében jelentkezik összesen hét állati váz, illetve vázrészlet. A tetemek alapvetően egy szinten fekszenek, a betöltési szint egyenetlenségéből adódóan a ló maradványai a többinél kicsit magasabban vannak, az árok ÉNy-i oldalánál. A többi váz inkább az árok DK-i oldalában koncentrálódik. Az állatok váza környékén nagyobb felületekben azt a betöltési szintet is sikerült megfigyelni, melyet rengeteg telephulladék, főként állatcsont jellemzett szétszórva a felületen. Minden arra mutat, hogy a tetemek idekerülése pillanatában az árok e megfigyelt betöltési szintje alkotta a felszínt, ami a széles árok még nem teljes feltöltődésére, illetve a betöltés folyamatos tömörödése miatti megsüllyedésre utal.

A széles árok több települési objektumot is felülrétegez. Ezek közül számunkra a 41. épület a fontos, aminek az ÉNy-i oldalára kétségtelenül ráfed.

41. épület. Egy kb. 4,5×5 m nagyságú, szabályos téglalap alapterületú, földbe mélyített épület. Alja mintegy 1,5 m mélyen van az altalajban, ami az Árpád-kori járószintet tekintve több mint 


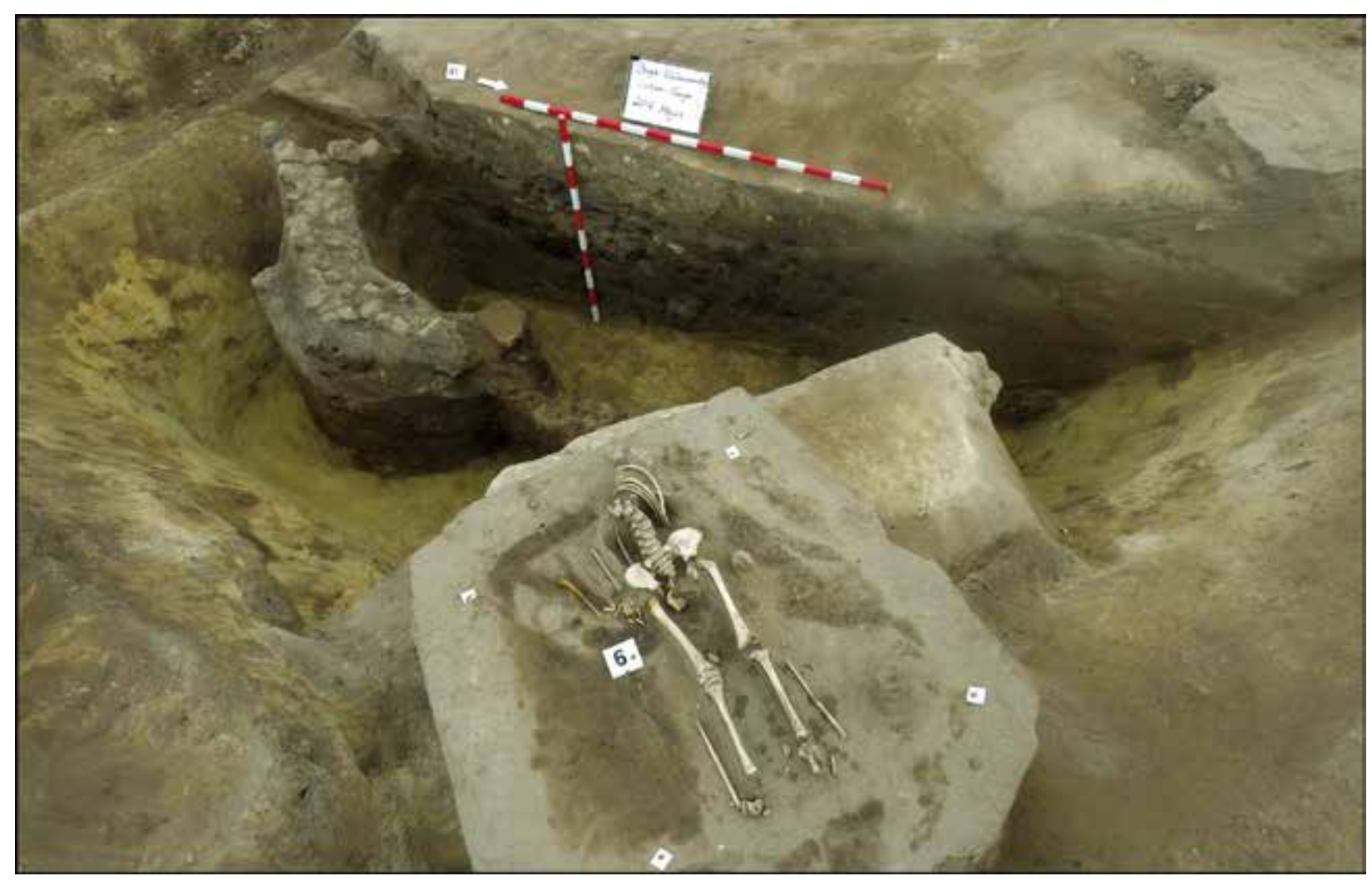

19. kép. Bugac-Felsőmonostor. A 41. épület (pince) és felette a humuszban fekvő 6. kisgyermek váza

Fig. 19. Bugac-Felsőmonostor. Building 41 (cellar) and the child skeleton (No. 6) overlying it in the humus

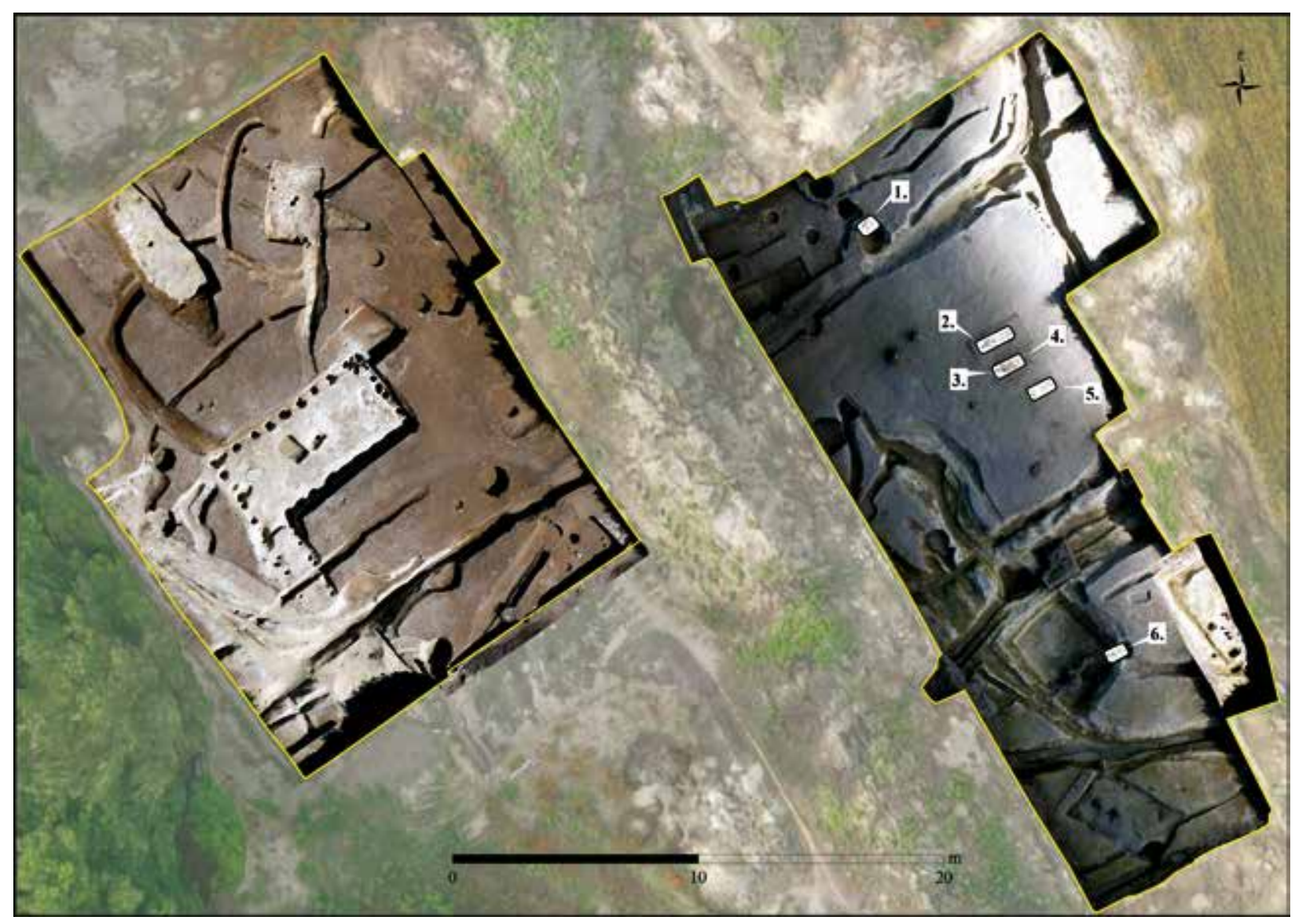

20. kép. Bugac-Felsőmonostor. A 2016-ban feltárt településrészlet

Fig. 20. Bugac-Felsőmonostor. The settlement section excavated in 2016 


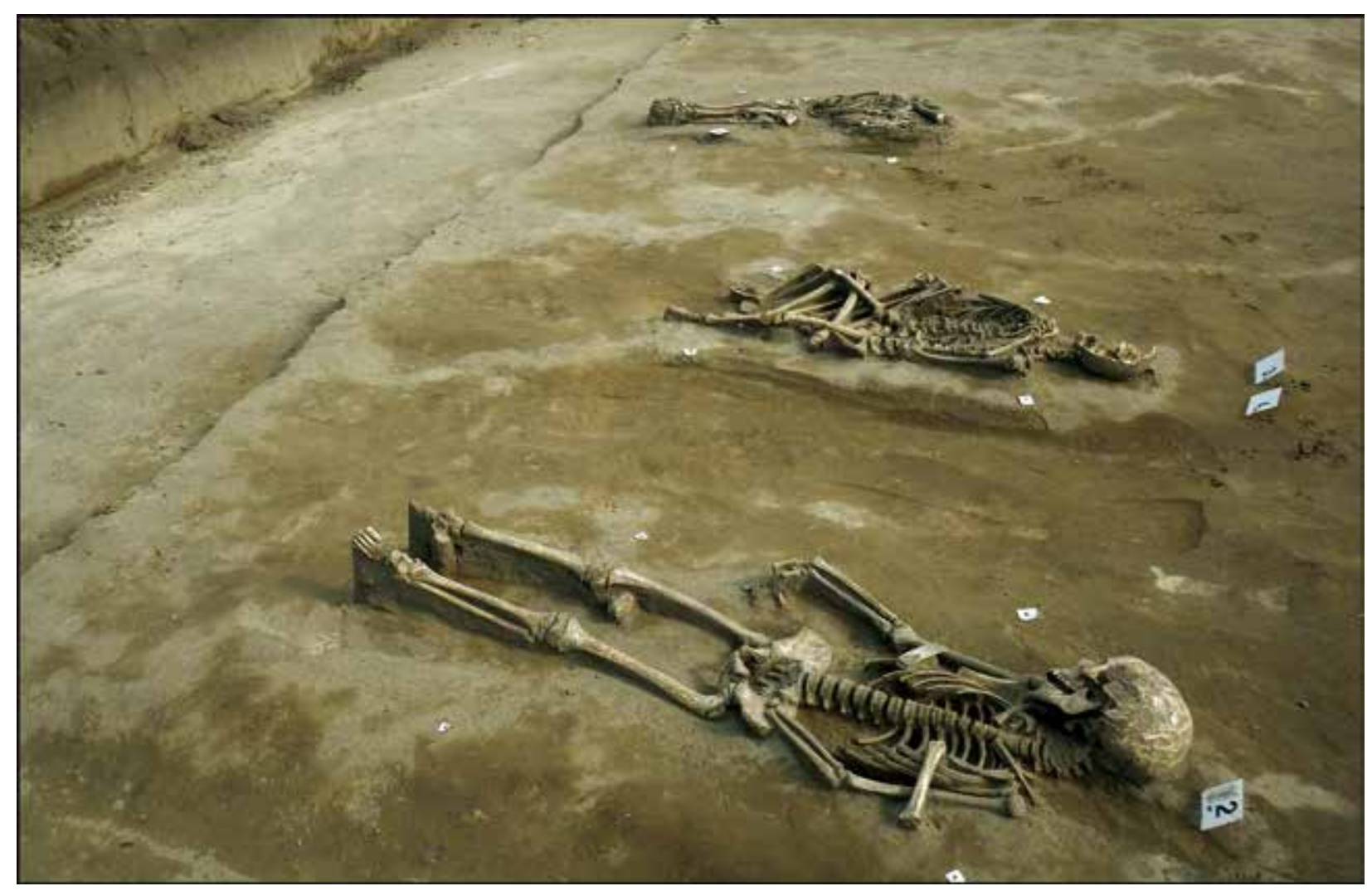

21. kép. Bugac-Felsőmonostor. A 2-5. számú, sorba fektetett gyermekvázak

Fig. 21. Bugac-Felsőmonostor. Child skeletons laid in a row (Nos 2-5)

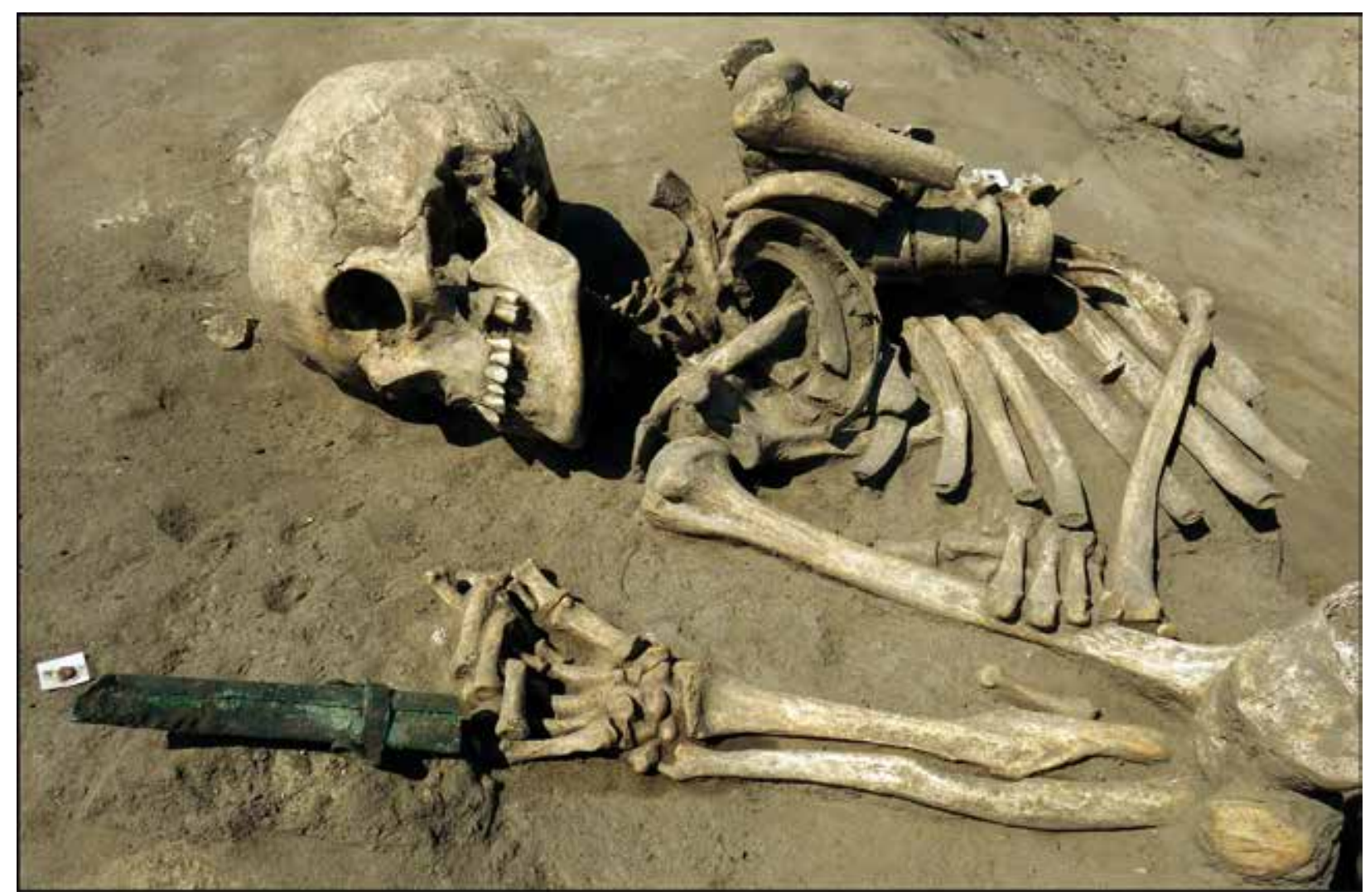

22. kép. Bugac-Felsőmonostor. Az 1. számú, zsugorított pozícióban fekvő női váz részlete az eredeti helyzetében megtalált bronz tőrhüvelyborítással

Fig. 22. Bugac-Felsómonostor. Detail of the crouched female skeleton (No. 1) and the bronze dagger sheath fittings found in situ 
$2 \mathrm{~m}$ mély beásást mutat. Az épület oldalai meredeken rézsúsek, minden oldalánál szabályosan szúkülnek, egy 3,4×2,5 m nagyságú, szabályos téglalap alapterületet alkotva. Semmilyen lejáratnak meghatározható jelenség nincs az oldalában. Ugyanígy cölöpökre utaló gödör, mélyedés sincs benne. Betöltése agyagos, jellegzetes, épületekre jellemző betöltés, kiemelten nagy mennyiségú kő- és téglatöredékkel. Leletanyagában sok kerámia és állatcsont mellett három, a 12. század közepére keltezhetó anonim denár is volt. A jelenség értelmezése nem e tanulmány célja, mindenesetre ezt a rézsűs falú, kifejezetten mély, nem ágasfás szerkezetú földbe mélyített épületet olyan pincehelyiségnek lehet meghatározni, melynek a földfelszín fölé emelkedő kő-tégla és agyagfelépítményével is számolnunk kell. Témánk szempontjából kiemelten fontos, hogy a 6 . kisgyerek váza e betöltés tetején, a nyesési szintünknél is jelentősen magasabban feküdt (19. kép). Ezek szerint a felszínnek csak kisebb mértékú süllyedésével kell számolnunk, vagyis az épület a gyermek vázának odakerülésekor már régóta feltöltődött. Ugyanezt erősíti meg a 31. árokkal való kapcsolata is, mely szintén felülrétegezi. Ny-i sarka felett magasan a 43. macska váza feküdt, de a rétegtan törvényei alapján kétségtelenül a 31. árok nyomvonalában, ahhoz tartozva. Minden azt mutatja, hogy a 41. épület egy korábbi, a 12. századi települési fázishoz tartozó földfelszíni épület pincehelyisége, melynek lebontása és feltöltése után még legalább két fázis, a 31. árok kiásása és használata, illetve annak betöltődése és a pusztulási horizont által jellemzett két időszak különíthető el.

A pusztulási horizont által érintett objektumok sokfélék, összefüggéseik miatt legalább három települési fázis részei. A 41. pincés épület igen jól adatolhatóan a 12. század közepén, inkább annak második felében kerül használaton kívülre, majd betöltésre. Aztán kiássák a legtöbb jelenséget tartalmazó 31. árkot és minden bizonnyal az ezzel megegyező irányú, tehát e településstruktúrához illeszkedő 14. árkot, valamint a 7. számú leégett épületet megelőző 8. és 9. árkot. Ezek szinte teljes feltöltődése után mutatkozik a település életének a vége az emberi és állati vázakkal, valamint az akkor használatban lévő, leégett 7 . épülettel. A 7. leégett melléképület felszerelési tárgyai közül több is teljesen megegyezik a Gulyás Gyöngyi által Cegléd mellett feltárt épület leleteivel. Fontos megjegyezni, hogy a pusztulási horizontnak meghatározott jelenségeket és objektumokat már semmilyen települési jelenség nem bolygatta meg. Mindez megint arra mutat, hogy ezek való- ban a település legutolsó fázisához tartoznak. A 41. épület és a 40., méhkas alakú gödör szinte teljesen fel voltak töltődve, mire a két emberi váz a felső betöltési szintjükre került. Mégis ezek az objektumok jelenthetik a bizonyítékot arra, hogy a hosszú ideig tartó tömörödési fázisuk még nem ért teljesen véget a település pusztulásának pillanatában, így a járószinten kisebb mélyedések, egyenetlenségek voltak a 13. század közepén. Ezekbe a mélyedésekbe kerültek a megtalált holttestek. A 2-5. vázak esetében korábbi objektum által okozott talajsüllyedést nem láttunk. Mégis feltúnő az, hogy a 3+1 test egy ÉNy-DK irányú vonalra fúzhetô fel. Ez pedig tökéletesen megfelel a település alapvetó, mind az épületek, mind az árkok által meghatározott, évszázadokig fennálló települési struktúrájának (20. kép). Habár esély sincs arra, hogy a felvetés bizonyítást nyerjen, mégis az a magyarázat túnik elfogadhatónak, hogy valamilyen sekély, éppen csak a kultúrrétegbe lemélyedő, ezzel egy járószintsüllyedést eredményező jelenséggel kell számolnunk. Talán egy sekély vízelvezetó árok lehetett az az objektum, amelybe belelökték az áldozatokat. A 2. váz magasan fekvő lába, kissé homorú helyzete legalábbis megengedi ezt a feltételezést (21. kép).

\section{Tárgyleletek}

Tőrtok borítólemeze. A pusztulási horizonthoz kapcsolódó lelet, ami közvetlenül az 1. fiatal nő félig nyitott állapotban lévő jobb kézfeje mellett feküdt (22. kép). A $12 \mathrm{~cm}$ hosszúságú tokszerü, hosszúkás, egyik vége felé keskenyedő tárgyat egy eredetileg téglalap vagy enyhén trapéz alakú lemezből hajlították háromszög átmetszetûre. Felső harmadánál egy lemezből kialakított pánt és kétoldalt bronzszegecsekkel hozzáerősített két akasztó szolgálta a felfüggesztést. A tárgy szembetűnő jellemzője a hosszra meróleges, egymással nagyjából párhuzamos rovások sora. Az elvégzett metallurgiai elemzés szerint anyaga relatíve magas (14-16\%) óntartalmú és valamivel alacsonyabb (3-6\%) cinktartalmú rézötvözetből van, ami jelentős mennyiségben ólmot is tartalmaz. A tok komplex archeometriai vizsgálata alapján kijelenthetó, hogy az összesen 10 rovás nem egyenlő mélységú, szélességú és hosszúságú. Eloszlásuk alapján bizonyos, hogy illeszkednek a pánthoz, tehát csak a "kész termékre” kerültek rá. Kialakításuk egy éles, hosszabb tárgygyal, talán valamilyen késsel történt, aminek két esetben félrevágás lett a következménye. A rovások szélén található sorja is kizárja annak lehetôségét, hogy a kialakításhoz használt szerszám 


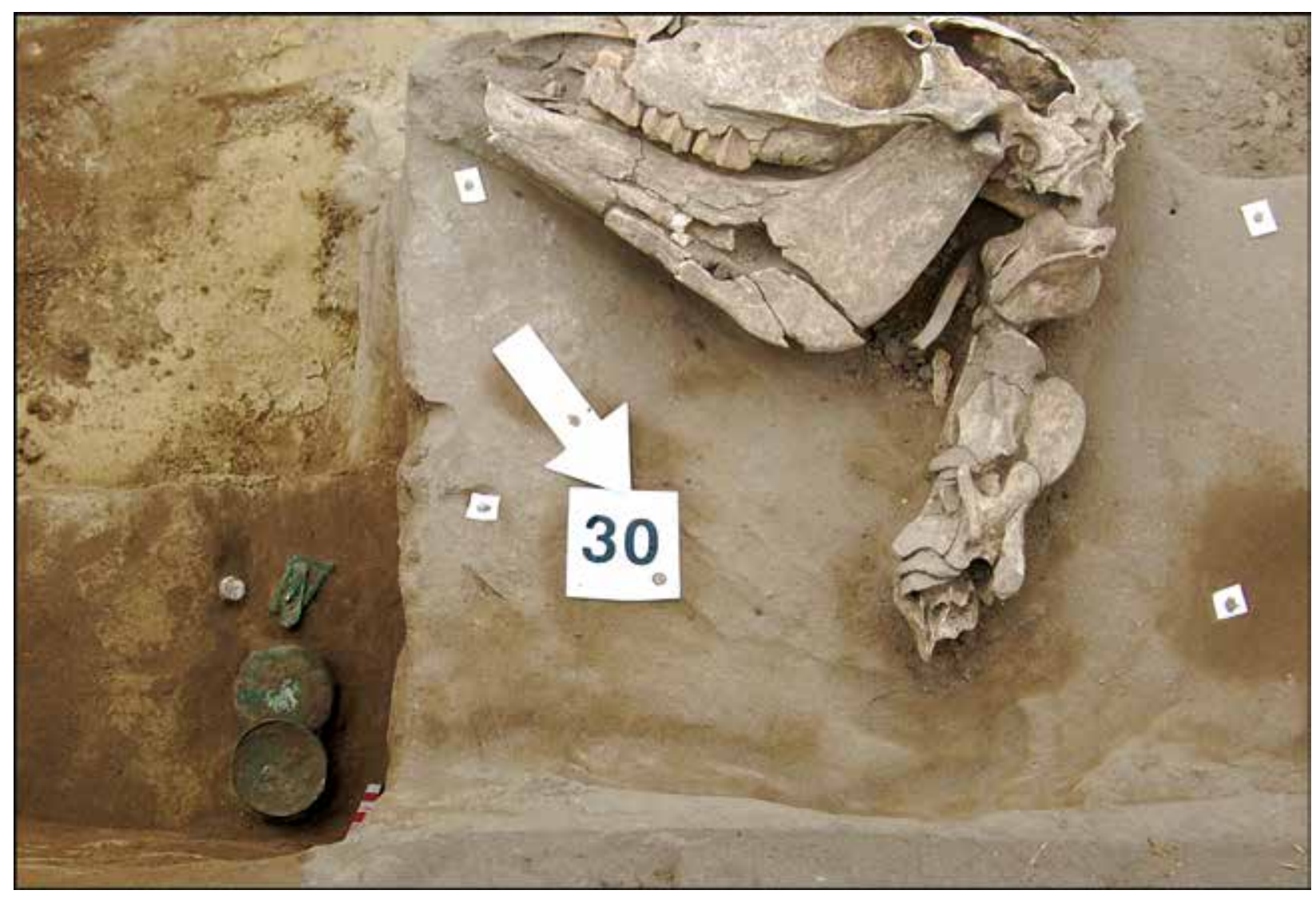

23. kép. Bugac-Felsőmonostor. A 31. árok felső betöltési szintjén fekvő 30. lófej és az árokba rejtett csuklós karú mérlegegyüttes eredeti helyzetükben

Fig. 23. Bugac-Felsómonostor. Horse head (No. 30) in the upper fill level of Ditch 31 and the folding balance scale concealed in the ditch, both in situ

egy véső vagy reszelő lett volna. ${ }^{33}$ A rovások jellegzetességei összességében semmiképpen sem hagyományos értelemben vett díszítőmotívumra utalnak, legalábbis elsődleges szándékból, a készítő részéról semmiképpen sem. A tárgy leginkább egy fatok borítólemezeként azonosítható teljes hosszában meglévő háromszög átmetszete szerint, egy annak megfelelő alakú tokra volt rászorítva. Mindez felveti annak lehetőségét, hogy nemcsak a tok, hanem az egykor benne elhelyezett egyenes penge is háromszög átmetszetú lehetett. Bár a rendelkezésre álló információk alapján analógiái nincsenek, de a tárgy hossza, felfüggesztése és egyéb jegyei alapján a leletet egy háromszög átmetszetú vékony tơr hüvelyének borításaként lehet leginkább értelmezni (24. kép a).

Csuklós karú mérleg és szerelékei. A 31. árok betöltésében, a 30. lófej közelében, részben alatta volt egy bronz mérlegkarból, két hozzá tartozó

33 A komplex archeometriai vizsgálatokat a Miskolci Egyetem Archeometallurgiai Kutatócsoportjának tagjai, dr. Török Béla, dr. Barkóczy Péter és Kovács Árpád végezték el. serpenyőből és három ólomsúlyból álló, összetartozó tárgyegyüttes. A rekonstruálható pusztulási szintnél mintegy $40 \mathrm{~cm}$-el lejjebb feküdt, közvetlenül nem kapcsolódik a 30. maradványokhoz. Az ép, hiánytalan együttes helyzete szándékos elrejtést mutat, vagyis nem a tárgy véletlenszerú elhagyásáról van szó (23. kép). A csuklós mérlegkar három tagból áll, a karok hossza 5,9cm, illetve $6,1 \mathrm{~cm}$, a középső tagé 3,8 $\mathrm{cm}$. Nyitott állapotában a teljes mérlegkar 13,4 $\mathrm{cm}$ hosszú. A karok kerek átmetszetúek, a végük felé fokozatosan vékonyodnak, a középső taghoz illeszkedő végüknél a szokásos lapos, trapéz alakú kialakítás van. A karrészeket ennek megfelelően ferde csapolással illesztették a középső részhez, keresztben egy-egy szegeccsel erősítették össze. A mérlegkar felfelé összecsukható. A karok vége függőleges irányban enyhén kiszélesedve ellaposodik, keresztben egy-egy kis lyuk van rajtuk. Ezekben huzalból hajlított kis karikák csüngnek. A két karrész anyagának összetétele teljesen megegyezik ( $\mathrm{Cu} 99,57 \%$, Zn 0,17\%, Pb $0,1 \%$, melyeket ezek szerint szinte tökéletes tisztaságú rézhuzalból kalapálással alakítottak ki. 


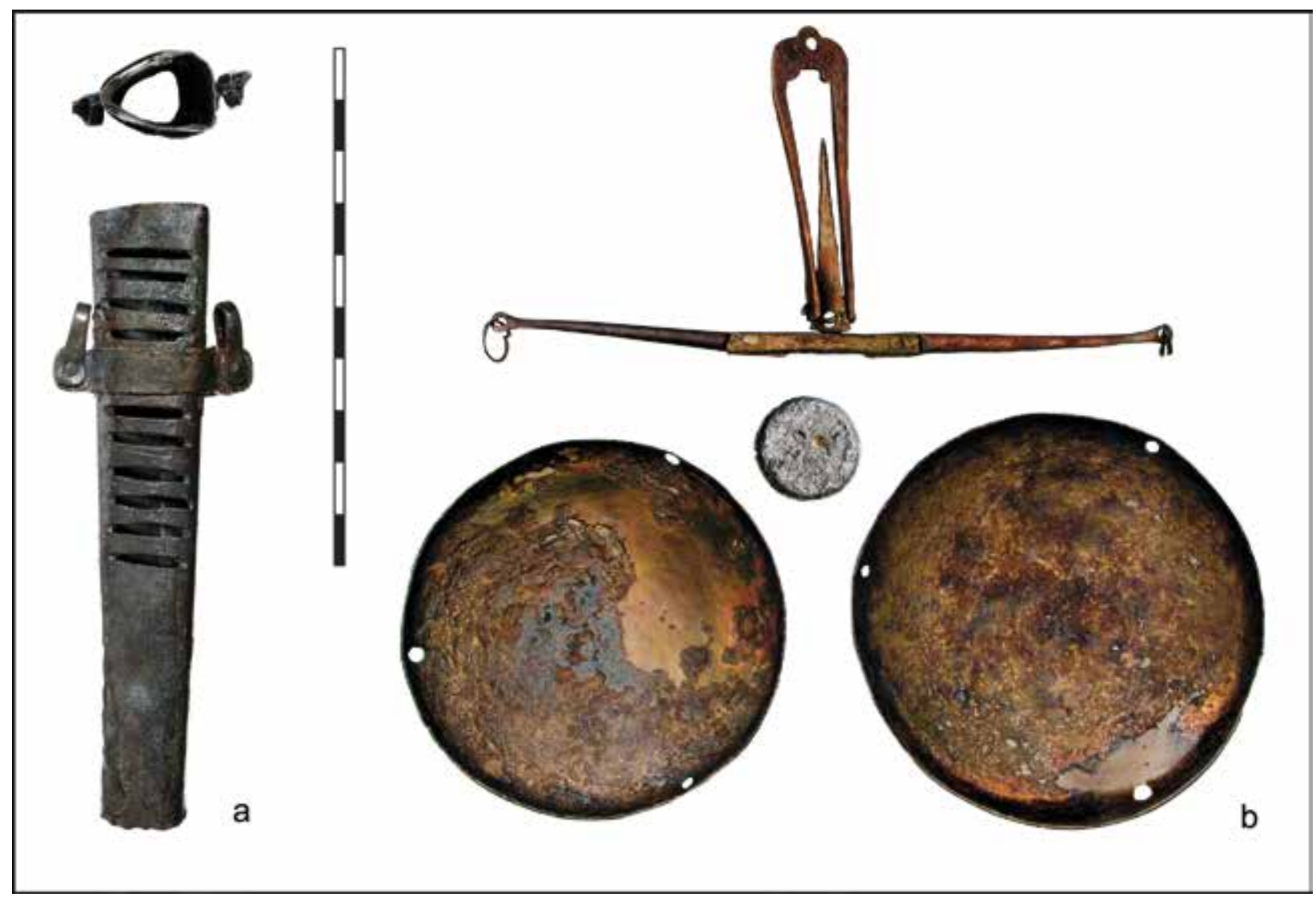

24. kép. Bugac-Felsőmonostor. a: bronz tórhüvelyborítás; b: csuklós karú mérlegegyüttes

Fig. 24. Bugac-Felsómonostor. a: bronze dagger sheath fittings; b: folding balance scale

A középső tag óntartalmú bronzötvözet $(\mathrm{Cu}$ $96,74 \%$, Zn 0,23\%, Sn 2,8\%), a közepénél van belehelyezve egy furatba a mérleg lemezból kidolgozott, háromszög alakú nyelve. Ehhez van kapcsolva a mérleg függesztője egy kis huzalból kialakított, meghajlott tengellyel. A függesztővillát (Cu 99,64\%, Zn 0,18\%, Pb 0,01\%) a két karrészhez hasonlóan szinte tiszta rézlemezból alakították ki, szárait a lemez eredeti síkjára merólegesen, lefelé kissé kiszélesedve laposra kalapálták. A függesztő felső része félkörös záródású kisebb lemez, legfelül középen átfúrt kis fül nyúlik ki belőle. A nyelvhez közeli belső részén lekerekített kis négyszögletes bevágás van. Reszelő nyoma csak a karok trapéz alakú részénél látszik. A mérleg a kisebb, díszítetlen, egyszerúbb kivitelú darabokhoz tartozik: Heiko Steuer felosztásában e különös ismertetójegy nélküli kart a 9. típusba sorolja. ${ }^{34}$ A leletegyüttes kisebbik serpenyője erős, de nem vastag bronzlemezből $(\mathrm{Cu}$ 95,29\%, Zn 1,77\%, Pb 0,02\%, Sn 2,77\%) készült, átméróje: $7,4 \mathrm{~cm}$. Az igényesen megoldott, kissé felhúzott perem alatt, egymástól némileg eltérő távolságra található a felfüggesztésre szolgáló három lyuk. A mérleg leletegyüttes nagyobbik serpenyóje szintén erós, de nem vastag bronzlemezból (Cu 93,29\%, Zn 3,62\%, Pb 0,29\%, Sn 2,68\%) készült, átméróje: 7,8 cm. Korrodálódott, így restaurálás során kisebb kiegészítésre szorult. A kissé felhúzott perem alatt, egymástól némileg eltérő távolságra található a három felfüggesztésre szolgáló lyuk. A készítési technika és a felhúzott peremkialakítás alapján bizonyosan egy múhely darabjai a párban megtalált serpenyők. Mindamellett a fémösszetétel-vizsgálat szerint alapanyaguk némileg különböző (24. kép b).

A kultúrréteg leletanyaga. Az emberi és az állati vázmaradványokon, a csontok között általánosan előkerült kő- és téglatörmeléken, valamint állatcsonttöredékeken kívül kerámiadarabok és egyéb fémleletek is voltak. A kerámiák általánosan Ârpád-kori, ennél pontosabb meghatározásra alkalmatlan töredékek. A kultúrréteg bontása során több 12. századi pénzérme is napvilágra került. E leletek csak közvetett módon kapcsolódnak a pusztulási horizont idejének meghatározásához. 
A 31. árokba rejtett mérleghez hasonló kétkarú mérlegeket szép számmal ismerünk Magyarországról. A szakirodalom Méri István és Fettich Nándor óta egyöntetúen Árpád-korinak határozza meg őket. Hiteles lelőkörülményekkel rendelkező darabokat korábban többségükben fontos központok, főként Óbuda és Esztergom területéről közöltek. ${ }^{35} \mathrm{Az}$ elmúlt évek feltárásai nyomán vidéki környezetből is egyre többet ismerünk. A legújabb kutatások alapján megállapítható, hogy az általában csuklós szerkezetú, kétkarú kézimérlegek - legalábbis általános - használata Magyarországon lezárul a 13. század folyamán. ${ }^{36}$ Érdekes egybeesés, hogy a hiteles régészeti ásatások révén megismert kézimérlegek többsége valamilyen formában kötődik a tatárjáráshoz. Az esztergomi együttes, a Szankon talált mérlegkar, a hejőkeresztúri és az orosházi serpenyők is közvetlen kapcsolatban vannak a tatárjárás pusztításával. ${ }^{37} \mathrm{~A}$ tura-szentgyörgyparti leégett udvarházban talált mérleg és a budaújlaki majorsági épületben feltárt serpenyők kapcsán is bizonyos, hogy a települések élete a 13. század közepén az ásató régészek szerint akár a tatárjáráskor ért véget. ${ }^{38}$ Ongán, az Árpád-kori településen a tatárjárás idején meggyilkolt áldozat, az igen jelentôs leletanyag és a kézimérlegkar együttes jelenléte - fóként az említett analógiákkal megerósítve - szintén több lehet, mint pusztán véletlen egybeesés. ${ }^{39}$ A mendei földvár égett pusztulási rétegét - melyből előkerült a mérlegegyüttes nem lehetett egyértelmúen a tatárjáráshoz kötni. Ugyanakkor az itt előkerült nyílhegytípust egyes kutatók a tatárokkal kapcsolják össze. Miklós Zsuzsa az erôszakos cselekményeket a 13. századra, legkésőbb annak végére teszi, így - legalábbis megközelítőleg - ebben az esetben is erről az idószakról lehet beszélni. ${ }^{40}$ Sályon a közlésből ugyan nehezen megállapíthatók a mérlegserpenyő lelőkörülményei, de az egyébként kis területen előkerült, gyanúsan nagy mennyiségú fegyver (számszeríjnyílhegy, kardpenge, kések, sarkantyúk, illetve zablák, patkók) sem általános velejárója egy Árpád-kori szokványos, szórt helyzetú leletanyagnak, még egy váraljai település esetében sem. ${ }^{41}$ Fettich Nándor az egyértelmú régészeti összefüggésben megtalált esztergomi mérleg kapcsán az ismertetett darabok többségé-

\footnotetext{
35 MérI 1954; FetTich 1968; BerTALAN 1998.

36 ROSTA 2017, 146-148.

7 WilHELM 2014; WOLF 2014; GyUCHA-RÓZSA 2014

8 MiKLÓS 1991; KÁRPÁTI 2002.

39 Az anyag jelenleg közöletlen, Szörényi Gábor szíves szóbeli közlése.

40 MiKLÓs 1981.

41 Mesterházy 1986, 94.
}

nek megégését és romlását szintén a tatárjárással kötötte össze - akárcsak Méri István az óbudai mérleg földbe kerülését. ${ }^{42}$ Habár nem minden esetben ismerjük e tárgytípus "leletté válásának" körülményeit, és még ha joggal valószínúsítjük is egyes esetekben az egyes alkatrészek véletlen elhagyását, mégis feltúnő, hogy az igazolt körülmények szerint e mérlegek leginkább valamilyen krízishelyzettel összefüggésben, jelen esetben a tatárjáráshoz köthetően kerültek a föld alá.

A mérlegkar, a serpenyők és a mérlegsúlyok szabályos és rendezett helyzete egyértelmúen arra mutat, hogy a monostori tárgyegyüttest nem elhagyták, elszórták, hanem szándékosan elhelyezték egy mélyedésben, tehát elrejtették. Mivel egy ilyen tárgy szabályos elásása a település központjában normál körülmények között nemigen képzelhetó el, így az elrejtés idejét feltételesen szintén azokhoz az eseményekhez kell kötni, amelyek a pusztuláshoz vezettek. ${ }^{43}$

A kézimérleg fontos és valószínúleg nem olcsó eszköz volt, vigyáztak rá, szükség esetén megjavították. Mivel általában kiváló minőségú rézből és bronzból készültek (a súlyok ekkor többségükben ólomból), így végsó tönkremenetelük után másodlagosan szinte biztosan felhasználták őket alapanyagként. Így történhet meg, hogy ásatások során az általános, ,"egyszerú" Árpádkori települési rétegekben, fázisokban nemigen találkozik velük a régész. A tatárjárás idején, amikor a mérlegeknél jelentősen komolyabb értékek is egyszerre a föld alá kerültek, és ott is maradtak, a visszatérésben így vagy úgy megakadályozott tulajdonosaik nem kutatták fel őket. A végleg felhagyott települések esetében ezek - egyéb értékekkel egyetemben - természetszerúen ott vannak a pusztulási rétegben, de máshol a visszaszállingózók és az új telepesek sem feltétlenül fedezték fel maradéktalanul az elrejtett kincseket. Ezzel lehet magyarázni, hogy a kézimérlegek - a tatárjárás egyéb régészetileg megfogható jelenségeivel együtt - egy sajátos, jól felismerhetó pusztulási horizont gyakori velejárói.

\section{A 2016. évi feltárás eredményei - következtetések}

Pétermonostora 11-13. századi temetóje a kolostor alatt és annak környékén legalább 160 méter távolságra van a 2016. évi feltárástól. A 14-16.

42 FETTICH 1968, 163; MÉRI 1954, 114.

43 Az elmúlt években intenzív fémkeresőzéssel a település területéról eddig hat csuklós karú és három egyenes karú mérleget, egy további függesztőt, valamint 14 serpenyőt és közel 400 ólomból készült mérlegsúlyt gyújtöttünk össze. 


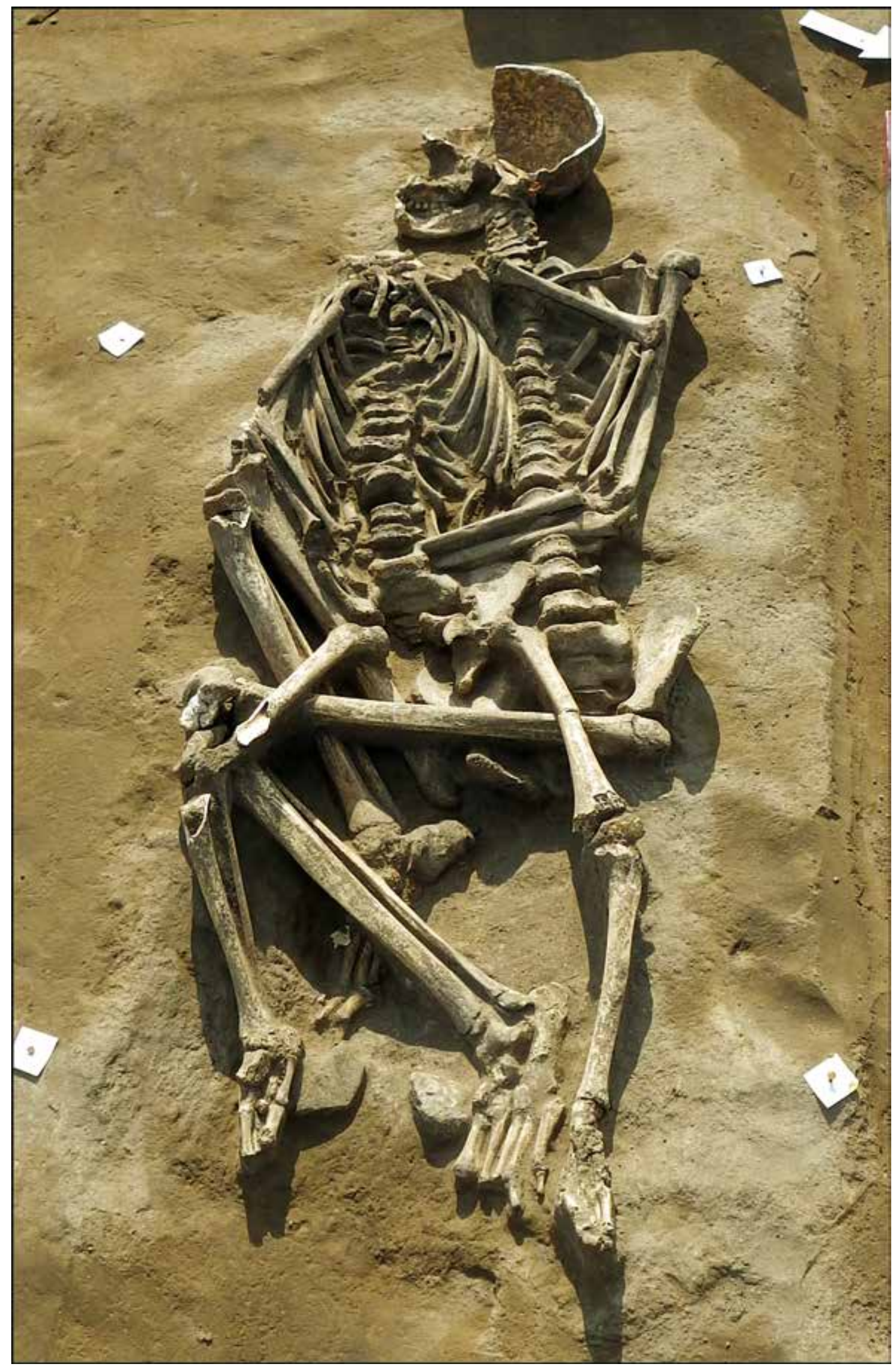

25. kép. Bugac-Felsőmonostor. A 3-4., egymáson fekvő gyerekvázak

Fig. 25. Bugac-Felsőmonostor. Child skeletons on top of each other (Nos 3-4) 
század között használt plébániatemplom körüli temető is több mint 150 m-re fekszik az ásatás helyszínétől. A nagy távolság és a köztes területen folytatott régészeti feltárás, a további kutatások, valamint a települések szerkezetének részleges ismeretében egyaránt kizárható, hogy bármely időszak temetôjének részletét, szélét tártuk volna föl. A vázak a késő középkori falut tekintve annak legszélén, az Árpád-kori településnek szinte a közepén feküdtek, nagy távolságra a temetőktől. A hat emberi váz helyzete a középkor temetkezési szokásaival, hagyományaival semmiképpen sem egyeztethető össze.

Mindezeket figyelembe véve nem merülhet fel kétség azt illetően, hogy a személyek és az állatok pusztulása és földbe kerülése nem mindennapi körülmények között történt. A többé-kevésbé roncsolt vázakon ugyan egyértelmú külsérelmi nyomot nem talált az antropológiai vizsgálat, mégsem kérdőjelezhető meg, hogy tömeges gyilkosság áldozatairól van szó. Így a 2016-ban elókerült hat egyénen kívül a kolostor keleti szárnyában 2013-ban feltárt, rendellenes módon, zsugorított helyzetben fekvő két fiatal váza, valamint egy felnőtt egyén vázrészlete is joggal ebbe a körbe sorolható (26. kép). ${ }^{44}$

A középkori Magyar Királyság, valamint Pétermonostora és a térség története ismeretében két időpontra szúkíthető egy olyan pusztítás lehetősége, amikor az emberek tömeges leölése után elmaradt a „rendcsinálás”, és így az állati tetemek és az emberi testek az általunk megtalált helyzetükben maradhattak. Ez pedig a tatárjárás, vagy a 16. századi török támadások ideje. A pusztulással kapcsolatba hozható leletek azonban kivétel nélkül a 13. századra keltezhetők. A környezetben, a telepjelenségekben megfogható pusztulási horizont szintén a 13. századra mutat, mint ahogy a közeg, a kultúrréteg is csak bőséges Árpád-kori leletanyagot tartalmazott. Ráadásul, amíg a 16. század elsó feléból országosan sem ismerünk még hasonló jelenségegyüttest, addig a ceglédi, dunaföldvári, orosházi, csanádpalotai analógiák mind azt bizonyítják, hogy a tatárjárás következtében a monostorival szinte megegyező jelenségek kerültek felszínre. Vagyis temetetlen vagy telepobjektumokban fekvő, erőszakos halált halt, főként fiatal egyének, tömegesen elhullott állatok, elhagyott vagy elrejtett értékes tárgyak jelentkeznek a település utolsó fázisának jól érzékelhető elpusztulásával, leégésével együtt.

44 Rosta 2014, 211, 228. A kézirat lezárása előtt, 2017. év őszén a kolostor nyugati szárnyában egy további, e körhöz tartozó részleges gyerekvázat találtunk a pusztulási rétegben kiemelkedő régészeti leletek társaságában.

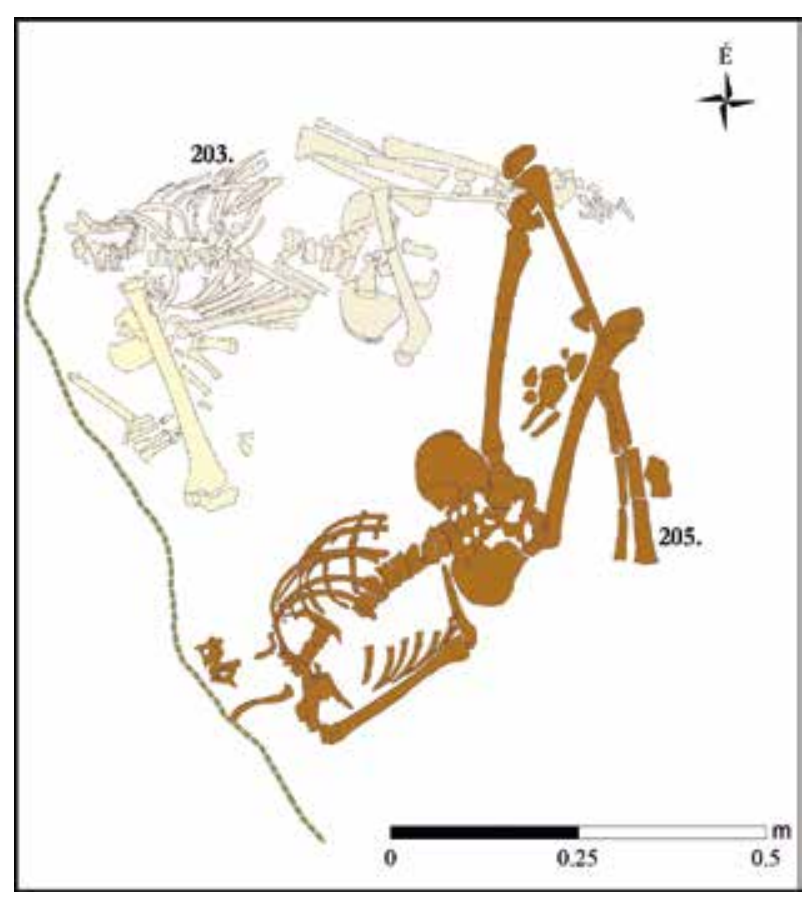

26. kép. Bugac-Felsőmonostor. A 2013-ban a kolostor keleti szárnyában feltárt, zsugorított pozícióban fekvő gyermekek és egy felnőtt egyén maradványai

Fig. 26. Bugac-Felsőmonostor. Remains of children and an adult in crouched position uncovered in the eastern wing of the monastery in 2013

A fentiek alapján nemigen lehet kétségünk afelól, hogy a Pétermonostorán feltárt tragikus események bizonyítékait is a tatárok számlájára kell írni.

\section{A kortárs források egyes adatai az újabb régészeti eredmények tükrében}

A tatárjárás időszakához, a birodalmakat megsemmisító és újakat teremtő mongol hadjáratokhoz szerteágazó és kiemelkedően gazdag forrásanyag kapcsolódik. Ahogy arra Felicitas Schmieder rávilágít, a 3-400 évvel korábban kalandozó magyarok és vikingek cselekedeteiről a forrásokat összeállítók még elsősorban hallomásból, szedett-vedett információkból szereztek tudomást. Így természetesen a kegyetlenségekről festett kép sokszor eltúlzott és sztereotipikus, sematikus lett. Ezzel szemben a 13. század közepén betörő tatárok tetteit Nyugat-Európa számára IV. Ince pápa megbízható „hírszerzők” segítségével tárta fel, akik már a katasztrófát követő években kiszálltak a helyszínre, szemtanúkkal beszéltek, tehát - legalábbis a korábbiakhoz képest - viszonylag pontos információik voltak. Az európai civilizációt ért addigi barbár támadásokkal szem- 
ben a tatárjárás kapcsán a korabeli történetírásban, illetve adatközlésben már jelentős előrelépést tapasztalhatunk. ${ }^{45}$ Ettől függetlenül persze még a hitelesnek tekintett kortársak beszámolói sem nélkülözik a régi, az antikvitás óta ,jól bevált" toposzok emlegetését a számukra érthetetlen, megmagyarázhatatlan helyzetekben. A némely esetben meseszerú, látványosan torzult információk mellett a szörnyúségek hangsúlyozása teszi az egyes beszámolók részleteit az utókor számára néha túlzóvá, kétségessé.

A tudomány számára értelemszerúen nélkülözhetetlenek a kézzelfogható bizonyítékok, amiket jelen esetben, ennyi év távlatából már kizárólag a régészet módszereivel lehet megszerezni. A tatárjárás kapcsán viszont éppen a régészet nem tudott sokáig számottevő konkrétummal szolgálni. Azonban az elmúlt tíz év fent vázolt ásatásai nyomán ma már a tatárjárás véres pusztításának közvetett bizonyítékai tömegesen állnak rendelkezésünkre. ${ }^{46}$

Jelen tanulmánynak nyilván nem célja valamennyi rendelkezésre álló forrás elemzése, de a kortárs beszámolók egyes idevonatkozó közléseinek hitelességét érdemes az új régészeti adatok nyomán megvizsgálnunk. Az elemzés alapját azon elgondolás adja, hogy a pusztítás képszerú leírásainak némelyike régészetileg is értelmezhető lehet. Gyucha Attila és Rózsa Zoltán az Orosháza-Bónum lelőhely elemzése során fogalmazták meg azon helytálló véleményüket, miszerint „a rendelkezésre álló írott források felhasználásával a támadások egyes jellemzőinek lehetséges régészeti implikációi meghatározhatók, majd azok alapján egy adott lelőhely adatainak vonatkozó analízise elvégezhető." 47 Feladatunk annak a megvizsgálása, hogy az írott források egyes állításai ténylegesen párhuzamba hozhatók-e a feltárt régészeti jelenségekkel.

\section{Éhezés - antropofágia}

Félegyházy József egy 1943-as összefoglaló tanulmányában elemezte a tatárjárásra vonatkozó forrásokat, amelyekben feltúnően sok adatot talált az éhezésre, ami a pusztítás nyomában járt. ${ }^{48}$ Rogerius saját tapasztalatai nyomán több helyen hangsúlyozza a gyötrő éhséget, de az ország általános állapotára vonatkozó sorai is vannak: „Mivel az emberek között az élelem hiánya miatt már pusztított a halál..."49 Spalatói Tamás egyenesen

\footnotetext{
45 SCHMIEDER 2005, 169.

46 Vö. LASZLOVSZKY 2003, 2012.

47 GYucha-RÓzSA 2014, 57.

48 FÉLEGYHÁZY 1943.

49 Rogerius 147.
}

így fogalmaz: „Ott hevert az utakon, a mezökön a rengeteg holttest, ezért általános volt a vélemény: az éhínség eme keserves csapása nem kevésbé pusztította a magyar nemzetet, mint a tatárok öldökló kegyetlensége." 50 Ugyanezt az éhség következtében megnyilvánuló katasztrofális állapotot mutatják be a későbbi magyar krónikák is, részint a fenti források, részint további kortárs tudósítások ismeretében. ${ }^{51}$

A kiskunmajsai lelőhely fontos jegyei a főként gyermekek csontjain talált vágásnyomok. Az antropológiai elemzés szerint az 1. épületben legkevesebb öt egyén csontjait érték vágások, melyek perimortem képződtek, vagyis valamilyen eszköz a halál időszakában, annak környékén okozta ezeket a sérüléseket. Nem lehet választ adni arra a kérdésre, hogy azokat a halált valamivel megelőzően, annak pillanatában vagy valamivel utána ejtették-e csontokon. Annyi bizonyos, hogy a csontmaradványok megégésekor vagyis a halált már bizonyosan követó időpontban - ezek a sérülések már megvoltak.

Mivel az erőszakos cselekményeknek velejárói lehetnek a csontokon a vágó- és szúrófegyverektôl eredő sérülések, így pusztán a vágások önmagukban még nem nevezhetők egyedi nyomoknak. Például az egyik orosházi áldozat sípcsontján is voltak fegyvertől származó vágásnyomok. ${ }^{52}$ Az 1/3. jelenségben lévő 8-9 év közötti gyermek jobb combcsontjának külső oldalán lévő kilenc rövid, párhuzamos, a csontokra merőleges irányú vágás azonban már mindenképpen kiemelkedő, a magyar antropológia számára eddig ismeretlennek minősülő jelenség. A felülről induló vágások közül az első egy erósebb behatást mutat, melynek következtében megakadt a penge, majd ugyanabban az irányban lefelé haladva a további vágások már gyengébb intenzitásúak, egyenletesek. Kétségtelen, hogy a párhuzamos vágások egyetlen, felülről lefelé haladó mozdulatsorral jöttek létre. A vágásnyomok ebben a formában semmilyen ismert fegyver vagy egyéb eszköz által ejtett hagyományos sérüléshez sem hasonlítanak. Jelenlegi tudásunk szerint ilyen típusú sérüléseket eddig kizárólag állatcsontokon sikerült megfigyelni. ${ }^{53}$ A többszöri antropológiai, majd archeozoológiai elemzés is arra az eredményre jutott, hogy ilyen vágásnyomok leginkább akkor képződnek, amikor éles eszközzel húst fejtenek le a csontokról. Az ebből eredő következtetés sze-

50 SPALATÓi 64

51 Képes KRÓNIKA 209, POZSOnyi KRÓNIKa 210, Szepesszombati KRÓNIKA 211.

52 GYUCHA-RÓZSA 2014, 60

53 A korabeli állatcsontokon megfigyelhető vágásnyomok legújabb, részletes feldolgozása: LYUBLYANOVICs 2017. 
rint a megtalált embercsontról valaki húst vághatott le. A természettudományok számára ismeretlen jelenségre, az emberi combcsonton mutatkozó húsolás nyomára - azaz a hús lefejtésének tényére - a történeti forrásokból kiindulva könynyen lehet magyarázatot találni.

A tatárjárást taglaló későbbi, 14-15. századi krónikákban általános kép az éhség következtében fellépő kannibalizmus. Ennél azonban fontosabb, hogy a 13. századi kortárs, a tatárjárást akár testközelből megtapasztalt szemtanúk közlése alapján íródott elbeszélések ezt tömegével említik. ${ }^{54}$ A 13. század végén Guillelmus de Nangiaco így ír: "Azt mondják, hogy ez után a tomboló öldöklés után akkora éhinség ütötte fel a fejét Magyarországon, hogy az élök megették a halottak testét. Meg kutyákat is ettek és minden effélét, amit csak fellelhettek." $55 \mathrm{Az}$ 1268-73 közt íródott Chronicon rythmicum Austriacum így fogalmaz: "Azt hiszem, ha a kőszikla szíveket kérdeznénk is meg, azok is megindulva szánakoznának a tatárok dühöngésén. Mert házastársak egymást nyomorultul falják fel; a fiak szüleiktől leöletnek.” Az 1292. évi Flores Temporum írja: „...olyan nagy éhség következett, hogy Magyarországon az anyák gyermekeiket megették." 56 Martinus Oppaviensis szerint: „Így... különösen Magyarországot annyira elpusztitották, hogy a rettenetes éhínség miatt az anyák gyermekeik húsával táplálkoztak és nagyon sokan egy bizonyos hegynek a porát használták liszt gyanánt."57 A heiligenkreutzi évkönyv írja az 1243. évről: „Kutyákat ettek, macskákat meg embereket; az emberhúst nyíltan árulták a vásárokon." 58 Az 1242 . évben született Planctus destructionis regni Ungarie per Tartaros, vagyis a "Siratóének Magyarországról, mikor a tatárok pusztították" címú irodalmi mú tragikus eseményeket személyesen átélt szerzőjének idevonatkozó sorai az irodalmi érték mellett tartalmilag is kiemelkedőek:

"Thereusok sokan lettek,
s Thereusnál bünösebbek:
szülö gyermekét levágja,
feni fogát önhúsára,
ki belöle vétetett.
Éhség tombol örült, véres,
testvér a testvérre éhes,
jó barát a jó barátnak,
az idegen bárki másnak
húsából nyer életet."59

\footnotetext{
54 FÉlegYhÁZY 1943, 73-74.

55 Guillelmus De Nangiaco 206.

56 FÉLEGYHÁZY 1943, 74.

57 MartinUs OpPaVIENSIS 207.

8 HeILIGENKREUTZI ÉVKÖNYV 204.

9 Planctus 161.
}

A kortárs krónikák egybehangzó adatai alapján tehát a háború, a járványok, a vetés elmaradása és egyéb környezeti tényezők következtében fellépő éhezés teret engedett a kannibalizmusnak a magyarok között.

A korabeli tudósítók azonban az ellenség, a mongolok kapcsán is közölnek kannibalizmusra vonatkozó adatokat. Carpini szerint az éhség a tatárokat is rávehette egyes esetekben erre: „Esznek kutyát, farkast, rókát, lovat; szorultságukban az emberhúst is elfogyasztják." 60 Egy ferences szerzetes, C. de Bridia 1247-es munkája, melynek alapját részben Carpini követjárása adta, négy alkalommal is ismétli Dzsingisz kán hadjáratai során a kannibalizmust. Munkája szerint a kán az élelem hiánya miatt minden tízedik mongol elfogyasztására ad parancsot. ${ }^{61}$ Péter orosz érsek 1241-44 között íródott levelében tudósít a „gyalázatos" állathúsok mellett szükség esetén a "nem nyers, de fótt emberi hús" evéséről a mongoloknál. ${ }^{62} \mathrm{Az}$ emberi maradványok éhezésból fakadó elfogyasztásán kívül egyes források a tatárok szörnyú tetteinek hangsúlyozásakor említik a kannibalizmust. A bordeaux-i érseknek szóló levelében Yvo de Narbonne a tatárok által Bécs környékén elkövetett szörnyúségekkel kapcsolatban írja: "Holttestüket a vezérek a kutyaevőkkel és más hulladékevókkel együtt úgy ették, mint a kenyeret... az öreg és csúnya asszonyokat úgy osztották étkül a közkatonának számító emberevőknek, mint a napi fejadagot..."63 Hasonló kép jelenik meg Simon de Saint Quentin 1248. évi Historia Tartarorumában, miszerint a tatárok ,felfalják az emberi testet, mint az oroszlán, de elönyben részesitik a tüzön sütöttet a föttel szemben." ${ }^{64}$ William Rubruck ferences szerzetes 1253-1255 közötti karakorumi tartózkodása során is különös, bizarr szokásokról - mint a gyermekeknek a szülők koponyájából való ivásról - ír, bár sokat mondó ezekról a dolgokról az a megjegyzése, miszerint „,beszéltem valakivel, aki látta ezeket". 65

Maga az antropofágia az általános vélekedéssel ellentétben a legkevésbé sem ismeretlen a nyugati kultúrában, szinte végigkíséri annak középkori és újkori történetét. Ennek megfelelően a történettudomány és az antropológia sokat foglalkozott a kérdéssel, a témának jelentős szakirodalma van Nyugat-Európában. A tatárjárást megelőző időszak európai példái sok esetben erősen egybecsengenek a 13. század közepének a

60 CARPINI 225.

61 GuzMan 1991, 35.

62 GuZMAN 1991, 34.

63 IVo De Narbonne 168.

64 PRICE 2003, 6.

65 GuzMan 1991, 38. 
magyarországi helyzetről szóló híradásaival. Rodulfus Glaber francia szerzetes és történetíró a 11. század két nagy éhínségéról ír a mai Franciaország területén. Az első az ezredforduló környékén történt, szerinte "az éhínség olyan brutálissá tette az népet, hogy felnött fiúgyermekek ették meg saját anyjukat, míg nők ugyanezt tették csecsemőikkel elveszitve minden anyai szeretetüket." Majd az 1032es évből az alábbiakról tudósít: „a pusztító éhség az emberi hús zabálásába taszította az embereket... számos helyen a holttesteket kikotorták a földböl, azért, hogy csillapitsák éhségüket. Ez a dühöngő örület olyan mértéküvé nőtt, hogy az embereket inkább útonállók támadták meg, mint magányos állatok. Az emberi hús fogyasztásának szokása annyira elterjedtté vált, hogy valaki megfózve vadállat húsaként árulta a tournus-i piacon." 66 John of Worcester az 1069-es évről írja, hogy Hódító Vilmos északi pusztítása nyomán az "éhínség következtében a férfiak lovat, kutyát, macskát és emberi lényeket ettek." 67 Talán a leghíresebb, az európaiakhoz kötődő eset az első keresztes hadjárat során, 1098-ban történt Ma'arra város ostroma után, amikor az éhségtől elcsigázott keresztesek az elesett muszlimok testéból ettek. ${ }^{68}$

Akárcsak késóbb a mongolok esetében, a krónikák a nyugatiak részéról is említik a a kannibalizmust a kegyetlen megtorlás, az ellenség megfélemlítése okán. Adémar de Chabannes közlése szerint 1020 körül Spanyolországban a normann Roger de Tosny egy szaracén foglyot szétvágatott, "mint egy malacot" majd megfózte a testrészeket, és "úgy tett, mintha enne" belöle. Egyes krónikaírók közlése alapján egyfajta pszichológiai hadviselésként lehetett szerepe az emberi testrészek elfogyasztásának. ${ }^{69} \mathrm{~A}$ keresztes hadjáratok során visszatérő motívumként jelenik meg a kannibalizmus az ellenség megfélemlítése céljából, mint a harmadik keresztes hadjáratban a Richárd királyról szóló történetek esetében is. ${ }^{70}$

Gregory G. Guzman felosztása alapján meg kell különböztetnünk az antropofágia három fajtáját - a túlélési, az általános és a rituális kannibalizmust. ${ }^{71}$ A középkori források természetesen nem tesznek különbséget e modern szociológiai és antropológiai terminológiák szerint, ám azok jellemzőit felfedezhetjük bennük. A fenti források alapján is jelentősen különböző jellemzőit láthatjuk az antropofágiának. Alapvetően két,

\footnotetext{
66 RuBENSTEIN 2008, 531. Osztényi Éva fordítása.

67 RUBENSTEIN 2008, 531.

68 RUBENSTEIN 2008.

69 RUbenstein 2008, 540-541.

PRICE 2003, 8-10.

1 GuZMAN 1991, 33
}

egymástól eltérő motivációt ismerhetünk fel: a kegyetlenségből, illetve az éhségből eredőt.

Erdemes talán elsőként az ellenség, a mongolok kapcsán szemrevételezni a források értékét. A 13. század közepéról származó legjelentősebb nyugati krónikák kivétel nélkül említik a mongolok kannibalizmusát. Ezzel szemben a mongolokkal régebb óta kapcsolatot tartó kínai, tibeti és muszlim források ezt egyáltalán nem említik. ${ }^{72}$ Mindazonáltal a mongolokkal kapcsolatban a nyugati forrásközlők többsége is főként csak túlélési kannibalizmusról beszél. A tudomány álláspontja szerint ez vészhelyzetben minden embernél, népnél előfordulhat életmentés érdekében, várostromok során vagy egyéb, a gyötrő éhséghez kapcsolódó helyzetben. ${ }^{73}$ Carpini vagy Bridia közlése nagyon is életszerú, hiszen a mongolok a hadsereg megmentése érdekében éhségüket csillapítva folyamodnak csak ehhez az eszközhöz éppen úgy, mint azt tették akár a keresztesek is 1098-ban. Ezzel szemben Yvo de Narbonne vagy Simon de Saint Quentin hallomásból szerzett információik alapján azt közlik, hogy a motiváció nem az éhezés, hanem a kegyetlenség, a barbárság volt. E klerikusok a világi és egyházi hagyományoknak megfelelően a görög és római, valamint a zsidó-keresztény kultúrkör korábbi íróinak nyomán hívják a nomád barbárt automatikusan kannibálnak, hiszen a kannibalizmus toposza a legrégebbi és leguniverzálisabb idegen- és ellenségkép. ${ }^{74}$ Bár némely krónikák közlése alapján a mongolok is ettek vagy legalábbis ehettek emberhúst Magyarországon, de az 124142. évi hadjáratuk során semmi nem indokolta, hogy kannibalizmushoz kellett volna folyamodniuk. Nincs okunk arra gondolni, hogy a tatárok élelem szúkében lettek volna, éppen ellenkezőleg, ők hajtottak el rengeteg állatot, ami az éhínséghez is vezetett. Így az ezzel kapcsolatos híradások valószínúleg inkább illeszkednek abba a sorba, mely félinformációk alapján a tatárok gaztetteit volt hivatva még inkább felnagyítani a keresztény nyugaton.

A magyar lakossággal kapcsolatban az emberhús evésére vonatkozó nagyszámú forrás kivétel nélkül a halálos éhséget jelöli meg kiváltó okként. A vonatkozó hiteles források nyomán igen nagy a valószínúsége annak, hogy az 1241-1243as évek éhínsége során történtek szélsőséges esetek. A kannibalizmus megjelenése persze nem lehetett általános jelenség Magyarországon, mindamellett abban sincs okunk kételkedni, hogy az ország egyes részein, ha elvétve is, de valóságo-

72 GUZMAN 1991, 32

73 GuzMan 1991, 33.

74 GUZMAN 1991, 39-40; SCHMIEDER 2005, 171. 
san számolni kell ezzel az eshetőséggel. Az éhínség következtében elóforduló antropofágia tényét talán nehezen lehet elfogadni, mindamellett az elszórtan előfordult a későbbi időszakokban is Magyarországon.1718-ban például Háromszéken jegyeztek le egy esetet, amikor a nagy szárazság következtében fellépő éhezés során megjelenik a kannibalizmus. ${ }^{75}$

A Kiskunmajsán régészeti feltárás során elókerült, majd antropológiai és archeozoológiai módszerekkel igazolt jelenséget, vagyis az emberi csontról való hús lefejtését a történeti források alapján meg lehet magyarázni. Az emberhús elfogyasztására az éhezésból eredő túlélési ösztön mellett egyéb magyarázat nemigen kínálkozik. Ezek alapján felvethető az is, hogy a település lakói - legalábbis részben - a pusztítással együtt járó éhezés áldozatai lettek.

\section{Vadállatok}

Az antropológiai értékelés a kiskunmajsai 2. épület egyik felnőtt női áldozatának sípcsontján postmortem állati rágásnyomokat mutatott ki. Rogerius idevonatkozó idézete különösebb magyarázat nélkül illik e jelenségre: „A föld azok felett a testek felett nyerte el az uralmat, amelyek a mérgezett lándzsáktól, kardoktól és nyilaktól hullottak el; ezeket a vérüktöl veres égi madarak és a fogakkal rendelkező szelíd és vadállatok rágták össze harapásaikkal gyalázatos módon, egészen a csontokig. ... Mert találni lehetett sok helyen még igen hosszú ideig megfeketedett, de el nem enyészett börrel bevont csontvázakat, mert az ilyenek az állatoknak nem szolgálnak kedvelt étekül, csak akkor, ha másféleképpen mentek tönkre."76

Mind Kiskunmajsán, mind 2009-ben Szankon olyan helyzet mutatkozott a feltárt épületekben, mely arra enged következtetni, hogy az emberi maradványok - legalábbis részben - másodlagosan kerültek az ásatások során megtalált helyzetükbe. Mindkét helyszínen egy utólagos területrendezés (az emberi és állati tetemek eltakarítása) történt, ami egyben azt a feltételezést is megengedi, hogy az áldozatok akár huzamosabb ideig is temetetlenül hevertek. Ebben az esetben a vadállatok minden különösebb nehézség nélkül bolygathatták a testeket, és így könnyen kerülhetett állati rágásnyom is a csontokra.

\section{Rablás és taktika}

A háború szinte állandó velejárója a rablás, amiról látszólag ellentétes híradások állnak rendelkezésünkre a tatárok kapcsán. Rogerius azt írja,

75 CSÁKI 2010, 280.

76 Rogerius 142. hogy a "tatárok csak az emberek legyilkolását szorgalmazták, és úgy látszott, hogy a zsákmánnyal a legkevésbé sem törödnek."77 Ezt Spalatói Tamás is megerősíti: „A szerencsétlen emberek kincsei, arany-ezüst edényei, bíbor öltözékei, számlálhatatlan fegyverei ott hevertek szanaszét az úton, de a tatárok hallatlan kegyetlensége mit sem törődött a zsákmánnyal, a drága kincsek egész zsákmányát semmibe véve csak az emberek leölésében dühöngött egyre jobban."78 A fenti idézetekben foglaltakkal ellentétben azonban Rogerius utóbb már így ír: „...és a zsákmány összeszedése után mind a férfiakat, mind a nöket, közrendüeket és förangúakat egyaránt leöldösték az utcákon, házakban és mezőkön." Majd később hasonlóan nyilatkozik: "A katonákat és úrasszonyokat, akik sokan voltak, kint a mezön az egyik oldalra, a parasztokat a másik oldalra állították, és miután elszedték tőlük a pénzüket, ruháikat és más javaikat... mindnyájukat fejszével és karddal kegyetlenül kivégezték." 79

A források alapján egyes esetekben a tatárok kirabolják áldozataikat, míg más esetekben csak a gyilkolás számít, nem törődnek a zsákmánnyal. A látszólagos ellentmondás azonban - jobban szemügyre véve a szövegek környezetét - jó eséllyel feloldható. Az elsó idézetek ugyanis a muhi csatát közvetlenül követő pillanatokra vonatkoznak, míg a továbbiak az éppen aktuális összecsapások utáni, mongol szempontból „nyugodtabb" eseményeket mutatják. Magyarán az ellenség összeroppantásának, megtörésének a hevében a tatárok nem foglalkoztak, nem is foglalkozhattak a rablással, hiszen megnehezítette volna az ellenség üldözését. E kötelező érvényư szabályról Plano Carpini teljesen egyértelmúen így fogalmaz: „Hasonlóképpen könyörtelen büntetést érdemel, aki zsákmányra portyázik, mielőtt még az ellenséges sereget teljesen legyözték volna; az ilyet a tatároknál minden kímélet nélkül megölik."80 A győzelem után hadászatilag már letisztázott helyzetben, vagyis az ellenséges támadás veszélye nélkül a halottakat aztán már könnyedén kirabolhatták, a foglyokat módszeresen kivégezhették, mint ahogy azt $A$ mongolok titkos története is tartalmazza: „Ha legyőzzük az ellenséget, nem állunk meg a zsákmánynál. Ha a győzelem végleges, úgyis miénk a zsákmány, és megosztozunk rajta."81

A régészeti eredmények e híradásokkal egybecsengve jelentősen különböző képet rajzolnak ki az egyes helyszíneken. Kiskunmajsán és Szankon nem látszik nyoma szisztematikus rablásnak,

\footnotetext{
77 ROGERIUS 143.

78 SPALATÓi 56.

79 ROGERIUS 145, 148.

80 CARPINI 250.

81 MTT 56.
} 
hiszen komoly értékeket sikerült legalábbis maguknál tartani az áldozatoknak. A ruhák tartozékai, illetve az ékszerek egyaránt azt mutatják, hogy az áldozatok kirablása, a forrásokban gyakran említett lecsupaszítása nem vagy csak hevenyészve történt meg.

Az egykori Pétermonostorán viszont teljesen más, ezzel ellentétes helyzet mutatkozik. Az áldozatoknál semmilyen ékszert vagy elrejtett egyéb értékes tárgyat sem találtunk. Feltúnó, hogy még a fenti helyeken nagy számban lévó ruhatartozékok, kerek bronzcsatok vagy egyszerú vascsatok sem voltak közelükben. Ugy túnik, hogy a monostor mellett - legalábbis a 2016-ban feltárt részen - egy módszeres kirablás előzte meg a kivégzéseket. Rogerius fent említett idézete mellett máshol is ír arról, hogy „...az ajándékozókat elvezették a völgybe, és ott rettenetesen kifosztva és meztelenre vetkőztetve, leöldösték ooket". ${ }^{82}$ Spalatói Tamás plasztikus közlése pedig különösen életszerúnek hat: „De hát miért emlegessem fel azt a kegyetlenséget, amely a városokban és falvakban nap mint nap látható volt? Amikor az összeterelt gyenge asszonyokat, öregeket és gyermekeket sorba ültették, s hogy a ruhájuk ne mocskolódjon be vérrel, s hogy a hóhérok se fáradjanak ki, előbb lehúzatták ruháikat; felemeltették karjaikat, és az odaküldött hóhérok csak akkor döfték tốreiket könnyedén a szívükbe; és így irtották ki valamennyit." 83 Vagyis ezekben az esetekben a rablás teljes volt, ami az áldozatok ruházatát is érintette, és a lemeztelenítéssel nyilván még inkább felerősítették a szerencsétlen foglyok kiszolgáltatottságérzését. A fenti idézetek tökéletesen megfeleltethetők a monostornál tapasztaltaknak, vagyis az áldozatokat minden kísérô lelet nélkül, valószínúleg teljesen lecsupaszítva ölték meg. Spalatói Tamás szavai ráadásul olyan valósághúen adják vissza a monostor mellett rekonstruálható történéseket, hogy még az is felmerülhetne, hogy pontosan írja le a Pétermonostorán látottakat. A levetkőztetés mellett különösen a gyermekek és nők sorba ültetése az a momentum, amit nemigen lehet minden alap nélkül, csak úgy pusztán kitalálni. A leírásnak ez a részlete semmiképpen sem toposz jellegú, mindenképpen közeli, egy szemtanú által személyesen átélt élményeket mutat be. Különösen annak fényében tünik reálisnak, hogy az antropológiai elemzés szerint legalább két egyént, az 1. fiatal nőt és a 4. gyermeket ülő vagy guggoló pozícióban ért el a végzet.

Carpini a tatárok hadviselésének ismertetésekor nagyjából a fenti, különféle helyzetekre vo-

\footnotetext{
82 ROGERIUS 148

83 SPALATÓi 57.
}

natkoztatható adatokat közöl: „Mikor háborúba készülnek, előőrsöket küldenek elöre... Ezek nem rabolnak, nem gyújtják fel a házakat, nem vágják le az állatokat, csak az embereket sebzik meg és ölik le... Utánuk következik a hadsereg; ezek mindent kifosztanak, ami útjukba akad..."84 Tehát a források és a régészeti eredmények nagymértékben igazolni látszanak egymást.

Nyilvánvaló, hogy minden egyes helyszín, minden csata és rajtaütés rendelkezett egyedi jellegzetességekkel, melyek miatt egymással tökéletesen megegyező lelőhelyeket és nyomokat nem lehet találni. Mindamellett a különféle típusú támadások alapvető, két fó jellemzőjét ezek alapján lehetségesnek túnik elválasztani egymástól. Az áldozatoknál vagy az épületekben a komolyabb értékek megmaradása valószínúsíti, hogy a támadás fó ereje nem az aktuális helyszín ellen irányult, hanem a katonai múveletek kezdetén vagy folyamán érte el a vég az áldozatokat. Mindazonáltal az egyes lelóhelyeken jelentkező leletgazdagságot erósen árnyalhatja sok, a mai a lehetőségeinkkel és tudásunkkal nem vizsgálható körülmény is, mint például az adott települések jogállása, típusa, az egyes legyilkolt emberek társadalmi, vagyoni helyzete; továbbá, hogy a menekülők tömegei esetenként lakóhelyüktől milyen messze, hol próbálták magukat meghúzni, ahol később aztán mégiscsak elérte őket a végzet. Így Wilhelm Gábor joggal vetette föl annak lehetóségét, hogy a kiemelkedő szanki arany leletegyüttes tulajdonosaiban akár módos menekülők csoportját is lehet sejteni. ${ }^{85}$ Fontos topográfiai adat, hogy mind Szankon, mind Kiskunmajsán az áldozatokkal teli földbe mélyített épületek csak az Árpád-kori település szélén, messze a központi résztől helyezkednek el. A tömeggyilkosságok helyszíneitől mintegy $1 \mathrm{~km}$ távolságra fekszik egy-egy kőtemplom. Régóta elfogadott nézet, hogy e helyek - több esetben megerősítve - az ellenállás lehetséges gócpontját jelentették. Ezt az idevonatkozó források mellett a régészeti kutatások is megerősítik, hiszen a környéken Csengelén, Tázláron, Félegyházán egyaránt régészetileg igazolható az erődítések léte. Bár a kiskunmajsai templom mellett még nem történt ilyen irányú vizsgálat, a régészeti feltárás szerint Szankon is bizonyosan sáncokkal erődítették meg a kőtemplomot. ${ }^{86}$ Ugyan nincs perdöntő bizonyíték a kezünkben, de a fenti öszszefüggések alapján felvethető, hogy mindkét tömeggyilkosság helyszíne csak a támadás elejét jelentette volna, annak fő célja a templom kör-

84 CARPINI 240.

85 WiLHELM 2014, 92.

86 Rosta 2014, 209-210. 
nyezete volt. Az áldozatok kirablása a támadás folyamatában tehát nem történt meg, sőt azt ismeretlen okból később sem hajtották végre a támadók.

A régészet eddigi hiteles eredményei szerint Esztergomban, Kisfaludon egy-egy, Muhin kettő, Hejőkeresztúron legalább hat, ${ }^{87}$ Cegléden kilenc, Orosházán 22, Dunaföldváron 33, Szankon 34, Csanádpalotán kettő, Ongán egy, Kiskunmajsán 34, Bugacon a korábbiakkal együtt összesen tíz embert lehet kétségtelenül a tatárok által - de legalábbis a tatárjárás kapcsán - legyilkolt áldozatnak tekinteni. A 2017-ben Szank-Kápolnahelyen történt ásatás során a templomot körülölelő, egyértelmúen védelmi jellegú, kettős körárokrendszerben nagy mennyiségú elszórt fegyver társaságában került elő egy újabb, hason fekvő áldozat.

A feltárások jellegéból adódóan a településeknek több-kevesebb részlete került csak elő; már a fenti lelóhelyeken is hatványozott számú áldozattal számolhatunk. Bár nem mindenhol történtek meg a szükséges adatfelvételek és vizsgálatok, és a közlésekból sem minden esetben derül ki a halál pontos oka, a szerteszét heveró holttestekből kiindulva a helyszínek - többségükben - a hirtelen rajtaütés jegyeit viselik magukon. Szank és Kiskunmajsa esetében egy valószínúsíthetó nagyfokú tereprendezés, utólagos takarítás teszi lehetetlenné az események menetének pontos tisztázását. Ezzel szemben Pétermonostorán a fentiek alapján úgy túnik, hogy egy régészetileg eddig még nem tapasztalt, ám - a forrásokból kiindulva - gyakori momentumot sikerült először megfigyelni. Itt szisztematikus kivégzés történt, melyet nem a csata hevében, hanem már hadászatilag tisztázott helyzetben, a támadást követően alkalmaztak. A feltárás során a vázakat ért roncsolások azért különösen sajnálatosak, mert éppen a kivégzés módjának esetleges további apró részleteit nem lehet megfigyelni a csontokon.

\section{Kor és nem kérdése}

Végezetül érdemes kitérni arra a jellegzetes helyzetre, ami a biztosan a mongolok által elpusztított emberek antropológiai azonosítása során a helyszínek többségénél azonnal feltúnik: az áldozatok kor és nembeli erósen egyenetlen eloszlására. Jelen ismereteink szerint több lelőhelyen még nem történtek antropológiai vizsgálatok, így a most ismert összesen 156 emberi maradványnak csak a vizsgált hányada alapján lehet

87 Wolf Mária szíves szóbeli közlése. következtetéseket levonni. ${ }^{88}$ Kiskunmajsán a két épületből összesen 34 halott részletei kerültek elő, itt 15 gyermek és négy fiatal mellett 13 nő és két férfi volt. Bugac-Pétermonostorán eddig nyolc gyermek és egy fiatal nő mellett egy meghatározhatatlan felnótt egyed maradványait ismerjük. Szankon 17 gyerek mellett 17 női áldozat volt a felgyújtott épületben. Dunaföldváron a 33 áldozatból 20 tartozott az infans-juvenis korcsoportba. A tíz felnőtt között öt nő és négy férfi volt, illetve egy nem meghatározható felnőtt, a többi három egyén maradványából nem lehetett megállapítani korukat és nemüket. Az orosházi adatsorban azonban a gyerekek és felnőttek aránya sokkal kiegyenlítettebb, fóként a juvenis és adultus korcsoportok dominálnak. Cegléden legalábbis a közölt fotók alapján szintén kiegyenlítettebb helyzet mutatkozik. Mindenképp figyelemre méltó, hogy a felnőttek ez utóbbi lelőhelyeken is inkább a fiatalabb korosztályba tartoznak, maturus és senium korú egyént jelenleg egyáltalán nem ismerünk ebből a körből. Mindezt figyelembe véve azt mondhatjuk, hogy a tatárjáráshoz kapcsolt tömeggyilkosságok helyszíneinek egyik jellegzetessége a gyermek és női áldozatok kiemelkedően magas száma. Kiskunmajsa, Bugac, Dunaföldvár és Szank 106 meghatározható egyede között 63 gyerek és fiatal mellett 36 felnőtt nő és mindössze hat felnőtt férfi volt. Mivel több helyszín számottevő nagyságrendú maradványáról van szó, ezeket a különbségeket nem lehet kizárólag a véletlennek tulajdonítani.

$\mathrm{Az}$ áldozatok kor, valamint nem szerinti megoszlása két külön kérdésként merül fel. Feltünó, hogy a tatárjárás áldozataként azonosított egyének között, egyetlen maturus vagy senium korú sincs. A vonatkozó források ezzel szemben gyakran említik az időseket is, fóként a gyerekekkel és nőkkel együtt, sőt a krónikások szerint e csoportok válogatás nélküli pusztítása a tatárok kegyetlenségének egyik fő megnyilvánulása. Az állításban nincs okunk kételkedni, így egyelőre nincs magyarázat az áldozatok között az idősebb korosztályok hiányára.

A beszámolók azonban kínálnak lehetséges magyarázatot az áldozatok nemek szerinti egyenetlen megoszlására. Carpini a tatárok hadviseléséről írja: „Az ellenfél élvonalával szembe egy foglyokból és velük hadakozó idegen népekböl álló csapatot küldenek..." E taktika lényegét később is megismétli: „....az itt elfogott emberekkel rontanak majd a másik országra... Ily módon a legyözött tartomány

88 A Tázlár-Templomhegy erődítési árkaiban talált két rendellenes pózban fekvő maradvány e körbe való besorolása jelenleg még nem egyértelmú. Gallina József Zsolt feltárásvezetővel folytatott egyeztetés alapján. 
lakóival pusztítják el a másik országot." ${ }^{89}$ Rogerius a Csanád megyei Pereg ostroma kapcsán ugyanerról a módszerról tudósít: „De az egész vidék elpusztítása után amazok orosz, kun és magyar foglyokból és kevés számú tatárból egyesitett tömegükkel mindenfelől körülvették a nagy falut, és a harcba a magyar foglyokat küldték elöre... és azokat, akik az övéikkel való harcból visszavonultak, legtöbbnyire vérszomjas kardjukkal megölték..."90 Rogerius beszámolója azon kívül, hogy szó szerint alátámasztja Carpini közlését, arra is lehetôséget ad, hogy párhuzamba hozzuk az egykori Pereghez közel fekvő Csanádpalotán feltárt lósírral. A felszerszámozott ló kétséget kizáróan keleti szokás szerint lett eltemetve, az ásatók egyébként helyes okfejtése szerint valószínúleg egy kun hátasának lehet meghatározni. Gallina Zsolt és Gulyás Gyöngyi is felvetik azt a kézenfekvő lehetőséget, miszerint a környéket a források nyomán is erősen érintő tatárjárásnak e kézzelfogható nyomait így a ló eltemetését is - csábító valamelyik akkor itt harcoló keleti nomád csoporthoz kötni. ${ }^{91}$ Tehát a férfiak szinte teljes hiányát a feltárt települések egy részénél leginkább azzal magyarázhatjuk, hogy egyrészt a csaták természetes szereplőiként eleve kevesebben vannak „otthon” a településeken, márpedig az új eredmények szinte kizárólag településrészletek feltárásából származnak. A források egyértelmúen nem szólnak róla és régészeti bizonyíték sincs rá, de következtethető az a természetes viselkedés, hogy a hivatásos katonáskodó elem mellett a nők és gyerekek menekülésének fedezését is főként a férfiak próbálták meg. Ezt látszik alátámasztani például Rogerius azon közlése, mely kifejezetten a nóknek és a természetszerúleg hozzájuk tartozó gyerekeknek az utolsó menedékekbe, az egyházakba való zárkózását mondja el Nagyvárad bevételekor. ${ }^{92}$ Emellett a forrásokból egyértelmúen kiderül, hogy a férfiakat tömegesen fogolyként, nagyobb munkabírású szolgaként használták leginkább hadászati célokra. Így különböző nemú csoportok fizikailag nemcsak egyes esetekben, de akár országos szinten is valóban elválhattak egymástól. Habár ez a magyarázat igen kézenfekvőnek túnik, a régészet még adós azokkal a csatahelyekkel vagy településrészekkel, amelyek a férfiaknak a nőkéhez és gyerekekéhez hasonló, tömegesen legyilkolt maradványait rejtik. Ehhez olyan helyszíneken kell a jövőben célzott kutatá-

\footnotetext{
89 CARPINI 241, 249.

90 ROGERIUS 148.

91 Emellett felvetődött az a magyarázat is, hogy a bánkúti kun sírhoz hasonlóan a tatárjárás után idetelepített kunok hagyatéka lenne a lótemetkezés. GulYÁs-GALLINA 2014, 158.

92 ROGERIUS 145.
}

sokat folytatni, ahol gyanítható a szervezett ellenállás. Ilyen lehet Szank-Kápolnahely kettős körárokrendszerrel megerősített temploma, ahol 2017-ben számtalan fegyver, nyílvesszók, kardok, buzogány, tőr, kések és egyéb fegyvernek használható tárgyak, páncéltöredékek társaságában került elő egy hason fekvő fiatal férfi váza a külső kerítóárok aljában. ${ }^{93}$ Mivel a hasonló, erődítésekkel körülvett Árpád-kori templomos helyekről való ismereteink folyamatosan bővülnek, az áldozatok várható számának emelkedésével talán lehetséges lesz a jövőben a különböző típusú lelőhelyek embertani anyagának összehasonlításával e felvetést igazolni, avagy cáfolni.

\section{Összegzés}

Aligha akad régész, aki bármely régészeti korszak temetőjének feltárása során ne találkozott volna az élet természetes (vagy esetenként talán kevésbé természetes) végével. A természetellenes vagy az egyértelmúen erószakos halállal való szembesülés azonban ettól mégis különbözik. Hatványozottan igaz ez akkor, ha az elhalálozás módja különös kegyetlenségre utal, vagy ha az tömegesen mutatkozik. Különösen lesújtó, amikor a társadalom leginkább védtelen elemei, gyerekek és nők tragikus pusztulásának bizonyítékai kerülnek napvilágra. A két fentebb ismertetett lelóhelyen ez a kíméletlen pusztítás kézzelfoghatóan jelentkezik, a nyomok pedig kétséget kizáróan az 1241-1242. évi tatárjárásra utalnak.

A korabeli forrásoknak még számtalan olyan vonatkozása van, melyet jelen tanulmány nem érintett. A leírtakból korántsem következik, hogy a tatárjárásról szóló korabeli forrásokat kritikai megközelítésnélkül kell elfogadni. Mindazonáltal arra rávilágít, hogy a régészettudomány előrehaladásával viszonylag rövid idő alatt is olyan ismeretekre tudunk szert tenni, melyek alátámaszthatják, de legalábbis új megvilágításba helyezhetik a korabeli írott források egyes adatait. Az utóbbi évtized eredményei nyomán egy új kutatási irányvonal született: a tatárjárás régészete. Vitán felül áll, hogy e néhány év során olyan mennyiségú és minőségú új régészeti adatot sikerült e témában összegyújteni, melyek a jövőben az egyes források kritikai vizsgálatakor a történészek számára is döntőek lehetnek. 


\title{
FÜGGELÉK
}

\section{JELENTÉS A BUGAC-FELSŐMONOSTOR-CSITÁRI TANYA LELŐHELYEN FELTÁRT ÖSSZEFÜGGŐ ÁLLATVÁZAK ARCHAEOZOOLÓGIAI VIZSGÁLATÁRÓL}

\author{
CSIPPÁN PÉTER
}

A fenti Árpád-kori lelőhelyről összesen kilenc összefüggó állati váz vagy nagyobb vázrészlet látott napvilágot. A régészeti megfigyelések alapján a tatárjárás idejére keltezhető vázak szórtan, a településen belül sekély objektumokból kerültek elő. Az állatok halálával összefüggésbe hozható, a csontokon is megfigyelhető nyomok, elváltozások mindössze egyetlen esetben azonosíthatók nagy bizonyossággal, míg a további vázak ilyen jellegú sérüléseket nem mutatnak.

A feltárt kilenc váz régészeti állattani szempontból is egyedülálló, hiszen nem csupán a hiánytalan vagy szinte hiánytalan vázak elföldelése, a korabeli háziállatfajok szinte teljes spektruma, hanem az egyedek kivétel nélküli fiatal életkora is figyelemre méltó.

\section{5. számú vázrész}

Egy fiatal felnőtt (subadultus) kutya (Canis familiaris L.) csaknem teljes váza (neuro- et viscerocranium, mandibula sin. et dex., atlas, axis, 4 vertebrae cervicalis, 11 vertebrae thoracalis, 8 vertebrae lumbalis, sacrum, 9 vertebrae caudalis, 23 costae, scapula sin. et dex. frg. humerus sin. et dex., radius sin., ulna $\sin .$, metacarpus II-IV. $\sin ., 2$ os carpale, pelvis sin. et dex., femur sin. et dex., tibia sin. et dex., fibula frg., astragalus sin. et dex., calcaneus sin. et dex., metatarsus II-V. sin. et dex., 8 os tarsale).

A fiatal felnőtt állat hosszúcsontjai teljes mértékben elcsontosodtak, a fogképlete teljes, a kor meghatározása a fogak minimális kopása alapján legfeljebb 2 év körülire becsülhető. A csaknem teljes vázból az állat jobb mellső végtagjának alsó része hiányzik, az ásatás során nem került elő. Az állaton több jelentős - nagy valószínúséggel az állat halálával összefüggésbe hozható - trauma jele figyelhetó meg (27-28. kép). A homlokcsont (os frontale) jobb oldala feltehetően egy jelentős nyomás vagy ütés hatására a szemüreg (orbita) felett beszakadt, ez a sérülés a törésfelületek alapján akár össze is függhet az állat halálával, illetve okozhatta azt. Az erőszakos elhullást erósítheti ugyancsak a koponya jobb oldalán megfigyelhetó mély, erőteljes vágás, ami az állcsontot (os maxillare) és az orrcsontot (os nasale) érinti. A traumák után az állat sebei már nem gyógyultak be, a sérült csontokon sarjadás nyomait nem lehetett megfigyelni, ezért a két trauma egykorúnak tekinthetó. Hatásuk együttese - feltételezve azok egyidejűségét - okozhatta az állat elhullását. Hasonló traumák több korszakból is ismertek a vonatkozó szakirodalomban. ${ }^{94}$

A kutya végtagcsontjaink vizsgálata során sikerült megfigyelni az akut ízületi gyulladás (arthritis) csontokra is kiható nyomait az állat bal oldali harmadik kézközép-

94 BARTOSIEWICZ 2013, 76. csontjának (metacarpus III. sin.) felső (proximalis) részén. ${ }^{95}$ A jelenség talán az állatnak az évszaktól független szabadban tartásával vagy az egyed élete során bekövetkezett kisebb-nagyobb inter- vagy intraspecifikus konfliktusokkal is magyarázható, amit az állat egyik bordáján megfigyelhetó callusszal gyógyult törés is alátámaszt. Ez utóbbi traumák aránya - a régészeti állattani anyagban megfigyeltek alapján - a legmagasabb a kutyák esetében megelőzve bármely más töréstípust. ${ }^{96}$

\section{6. számú vázrész}

Infantilis ló (Equus caballus L.) koponyája és nyakcsigolyái (neuro- et viscerocranium, mandibula sin. et dex., os hyoideum frg., atlas, axis, 3 vertebrae cervicalis).

Az állat fogváltása még nem fejeződött be, a tejfogak felszíne kopott, a csigolyák ízületi felszínei még nem csontosodtak hozzá a corpusokhoz. Ezek alapján az állat életkora maximum 16-18 hónapra (másodfél éves) tehető. ${ }^{97}$ A csontokon az elhalálozás okával összefüggésbe hozható trauma vagy kóros elváltozás nyomai nem figyelhetők meg.

\section{7. számú váztöredék}

Fiatal felnőtt (subadultus) szarvasmarha (Bos taurus L.) nyakcsigolyái:

atlas, axis, 5 vertebrae cervicalis.

A csigolyák ízületi felszíneinek elcsontosodása alapján az állat kora nem becsülhető pontosan, a csontok felszíne, textúrája nem kifejlett állatra utalnak.

\section{8. számú váz}

Fiatal (subadultus) házi macska (Felis domestica Briss.) csaknem teljes csontváza:

viscerocranium frg, mandibula dex, atlas, axis, 5 vertebrae cervicalis, 10 vertebrae thoracalis, 6 vertebrae lumbalis, sacrum, 15 costae, sternum frg., scapula dex. frg. humerus sin., radius sin. et dex. frg., ulna sin. et dex., metacarpus II-IV. dex., pelvis sin. et dex., femur sin. et dex., tibia sin. et dex., astragalus sin. et dex., calcaneus sin. et dex., metatarsus II-V. sin. et dex., 3 phalanges prox. ant./post.

A hosszúcsontok epiphysisein az elcsontosodás folyamata még nem minden esetben fejeződött be, ennek és a fogak kismértékú kopásának alapján az állat kora 1-1,5 év körülire becsülhető. ${ }^{98} \mathrm{Az}$ állat csontjain kóros elváltozás vagy az elhullás okaként értelmezhető trauma nyomai nem láthatók.

95 BARTOSIEWICZ 2013, 106.

96 BARTOSIEWICZ 2013, 60-61.

97 SCHMID 1972, 77; Hillson 1986, 338.

98 Newton-NunAmaKer 1985, Appendix (Table C2). 


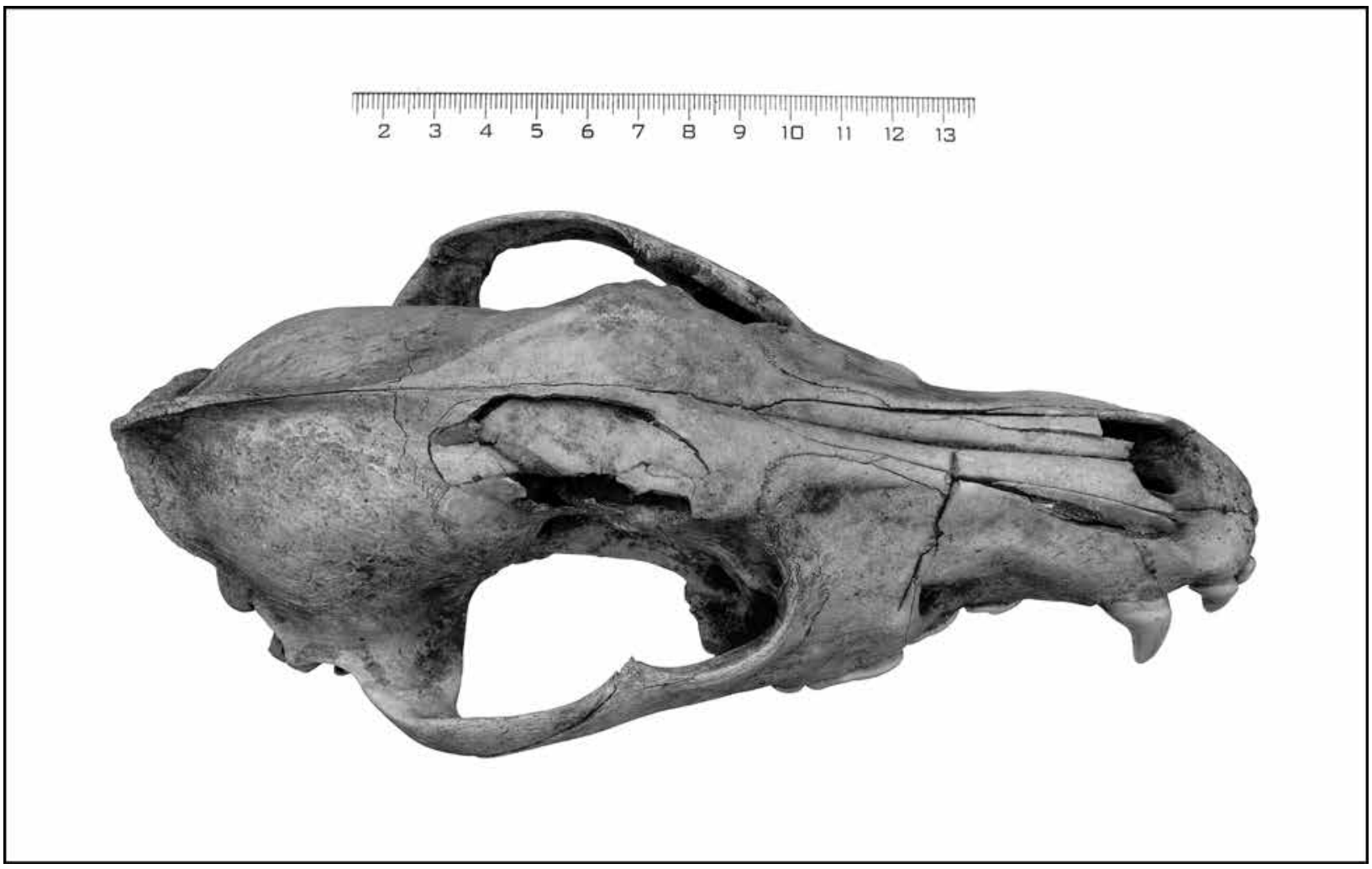

27. kép. Bugac-Felsőmonostor. Kutyakoponya törött homlokcsonttal és vágásnyommal az orr-részen

Fig. 27. Bugac-Felsőmonostor. Dog skull with broken frontal bone and cutmark on nasal part

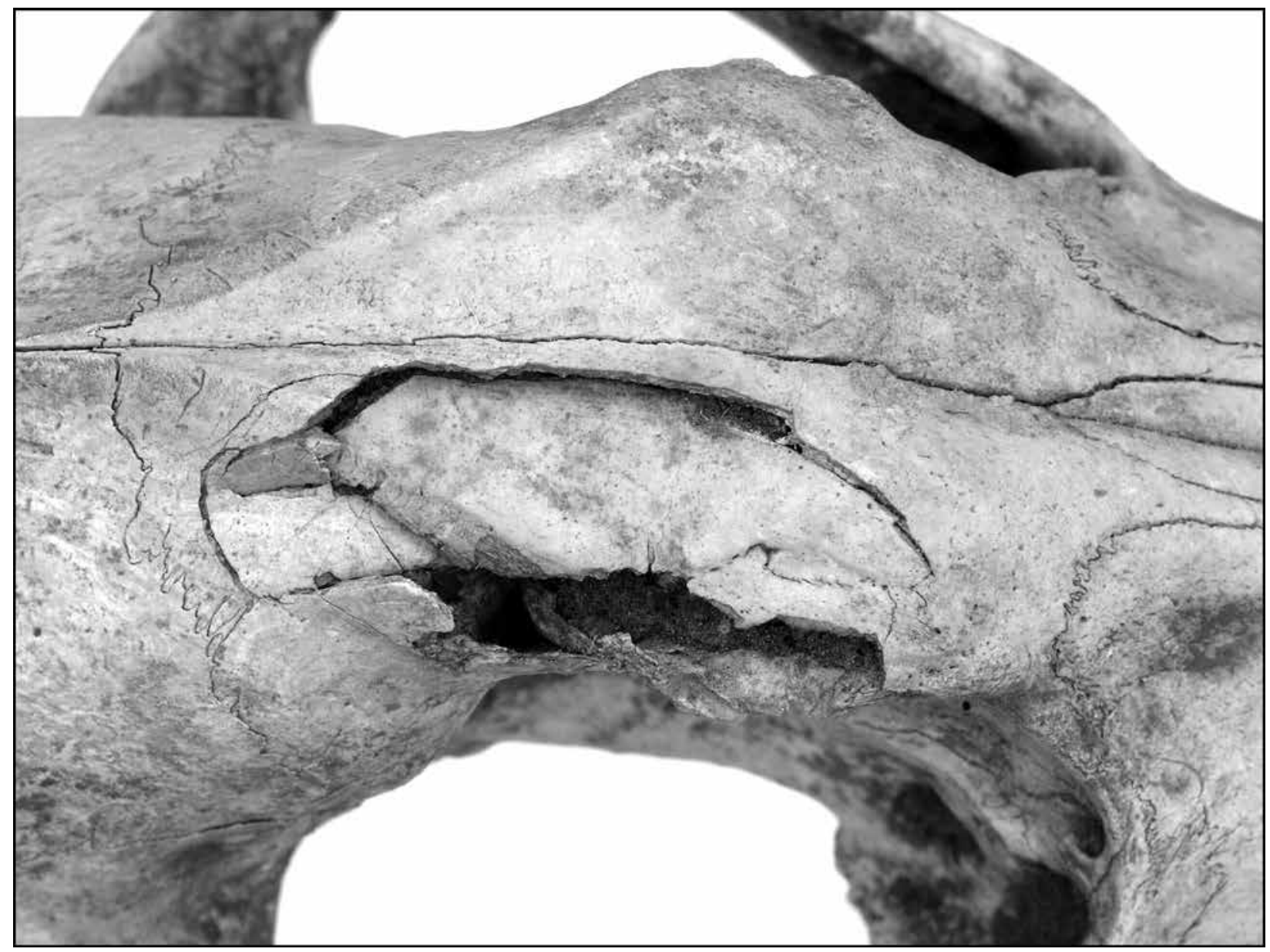

28. kép. Bugac-Felsőmonostor. A törött homlokcsont nagyított képe

Fig. 28. Bugac-Felsőmonostor. Magnification of the broken frontal bone 
A fenti csontokon kívül a betöltésből előkerült továbbá egy béka (Anura sp.) hosszúcsontja, valamint egy házi tyúk (Gallus domesticus L.) tibiotarsusának proximalis töredéke is.

\section{4/1. számú váz}

Infantilis szarvasmarha (Bos taurus L.)-borjú csontváza: neuro- et viscerocranium frg., atlas frg., axis frg., 5 vertebrae cervicalis, 13 vertebrae thoracalis, 6 vertebrae lumbalis, 19 costae frg., sternum frg., scapula sin. et dex. frg., humerus sin. et dex., radius sin. et dex., ulna sin. et dex. metacarpus III-IV. sin. et dex., 4 os carpale, pelvis sin. et dex. frg., femur sin. et dex. frg., patella sin., tibia sin. et dex., astragalus sin. et dex., calcaneus dex., os tarsale centrale sin., metatarsus III-IV sin. et dex.

Az állat kora a hosszúcsontok epiphysiseinek és a medence elcsontosodásának teljes hiánya alapján kevesebb, mint 6-9 hónap. ${ }^{99} \mathrm{Az}$ egyed csontjain kóros elváltozást, vágásnyomot, illetve az elhullással összefüggésbe hozható jelet nem lehetett megfigyelni.

A szarvasmarhaborjú mellól előkerült még egy fiatal kiskérődző (juh/ kecske) alsó állkapcsa, valamint egy kiskérődző bal alsó őrlőfog $\left(M_{2}\right)$, továbbá egy ugyancsak bal oldali, felső kifejlett szarvasmarha-előzápfog $\left(P^{1}\right)$.

\section{4/2. számú váz}

Infantilis szarvasmarha (Bos taurus L.)-borjú csontváza: neuro- et viscerocranium frg., mandibula sin. et dex., atlas frg., axis frg., 5 vertebrae cervicalis, 13 vertebrae thoracalis, 6 vertebrae lumbalis, 23 costae frg., scapula sin. frg., humerus sin. et dex., radius sin. et dex., ulna sin. et dex., pelvis sin. et dex. frg., femur sin. et dex. frg., tibia sin. et dex. frg., astragalus sin. 4 phalanges I. ant./post., 2 phalanges II. ant./ post., 1 phalanx III.

Az állat kora a hosszúcsontok epiphysiseinek, valamint a medence elcsontosodásának teljes hiánya és a fogak alapján 6-9 hónap lehetett. ${ }^{100}$ Az egyed csontjain kóros elváltozást, vágásnyomot, illetve az elhullással összefüggésbe hozható jelet nem lehetett megfigyelni.

A 44/2. számú váz mellól elókerült továbbá:

- egy kifejlett szarvasmarha bal oldali lapockájának töredéke,

- egy kifejlett kiskérődző (juh/kecske) jobb oldali combcsontjának diaphysis-töredéke,

- egy fiatal szarvasmarha bal alsó állkapcsának töredéke,

- egy kifejlett szarvasmarha jobb alsó állkapcsának töredéke,

- egy fiatal szarvasmarha jobb oldali kézközépcsontjának diaphysis-töredéke,

- egy fiatal szarvasmarha jobb oldali sípcsontjának diaphysis-töredéke,

- egy csaknem kifejlett szarvasmarha bal alsó állkapocsi őrlőfoga,

- egy kifejlett szarvasmarha hátsó proximalis ujjperce,

- egy kifejlett ló jobb oldali térdkalácsa,

- egy fiatal kiskérődző (juh/kecske) csaknem teljes jobb alsó állkapcsa,

- egy kifejlett ló csaknem teljes jobb oldali lapockája,

- egy nagypatás hátcsigolyájának töredéke,

- hat nagypatás-bordatöredék.
46. váz

Infantilis szarvasmarha (Bos taurus L.)-borjú hiányos váza, a caudalis rész hiányzik (neuro- et viscerocranium frg., mandibula sin. et dex., atlas frg., axis frg., 3 vertebrae cervicalis frg., 13 vertebrae thoracalis frg., 18 costae frg., scapula sin. et dex. frg., humerus sin. et dex., radius sin. et dex., ulna sin. et dex. metacarpus III-IV. sin. et dex., 1 phalanx I. ant. frg., 2 phalanges II. ant. frg.).

Az állat kora a hosszúcsontok epiphysiseinek és a medence elcsontosodásának teljes hiánya, valamint a fogak alapján maximum 6-9 hónap lehetett. ${ }^{101} \mathrm{Az}$ egyed csontjain kóros elváltozást, vágásnyomot, illetve az elhullással összefüggésbe hozható jelet nem lehetett megfigyelni.

A 46. számú váz mellől előkerült továbbá:

- egy kifejlett szarvasmarha jobb oldali kézközépcsontja,

- egy kifejlett szarvasmarha bal oldali sípcsontjának diaphysis-töredéke,

- egy kiskérődző (juh/kecske) jobb oldali orsócsontjának diaphysis-töredéke.

48. váz

Fiatal (juvenilis) sertés (Sus domesticus Erxl.) törzsének része (11 vertebrae thoracalis, 2 vertebrae lumbalis, 19 costae).

A csigolyák íveinek elcsontosodása alapján az állat nem tekinthető kifejlettnek.

A vázrészlet mellól egy fiatal szarvasmarha bal felső állkapocsi őrlőfoga $\left(M^{3}\right)$ is előkerült.

\section{9. számú váz}

Infantilis szarvasmarha (Bos taurus L.)-borjú hiányos váza, a fej és több végtagrész hiányzik (os hyoideum frg., axis frg., 4 vertebrae cervicalis frg., 7 vertebrae thoracalis frg., 4 vertebrae lumbalis frg., sacrum frg., 15 costae frg., sternum frg., scapula sin. et dex. frg., humerus sin. et dex. frg., radius sin. et dex. frg., ulna sin et dex. frg., metacarpus IIIIV. sin., pelvis sin. et dex. frg., femur sin. et dex. frg., patella sin., tibia sin. et dex. frg., astragalus $\sin$., calcaneus $\sin ., 4$ phalanges I. ant./post. frg., 1 phalanx II. ant./post. frg.).

$\mathrm{Az}$ állat kora a hosszúcsontok epiphysiseinek, valamint a medence acetabulum elcsontosodásának hiánya alapján legfeljebb 6-9 hónap lehetett. ${ }^{102}$ A csontokon az állat elhullásával összefüggésbe hozható kóros elváltozás vagy trauma jeleit nem lehetett megfigyelni. Az állat hasznosítására utaló darabolásnyom nem volt látható.

A 49. váz mellől előkerült továbbá:

- egy kifejlett nagypatás bordatöredéke, felszínén darabolásnyommal,

- egy kifejlett sertés fejgyámja (atlas), felszínén bárdolásnyommal.

A régészeti megfigyelések alapján a fenti állatmaradványok egy eseményhorizonthoz köthetők. Értelmezésük pusztán a zoológiai információk alapján nem lehetséges eltekintve a 15. számú kutyaváztól, ahol az állat elhullását egyértelmúen a koponyán látható traumák (vágás, törés) okozhatták. Figyelemre méltó azonban, hogy az elhullott állatok szinte kivétel nélkül igen fiatal egyedek, jóllehet az elhullásukat magyarázó, a csontokat is érintő elváltozásokat egyetlen esetben sem lehetett megfigyelni.

101 SILVER 1963, 253.

102 SILVER 1963, 253. 


\begin{tabular}{|c|c|c|c|c|}
\hline \multicolumn{5}{|c|}{ Mérettáblázatok } \\
\hline Obj. & Faj & Csont & Oldal & Méretek $(\mathrm{mm})^{1}$ \\
\hline \multirow[t]{12}{*}{15.} & kutya & koponya & & $\begin{array}{l}\mathrm{GL}=204,8 ; \text { Ent-Ent }=37,1 ; \text { Ect-Ect }=45,5 ; \mathrm{Zy}-\mathrm{Zy}=105,0 ; \\
\mathrm{Eu}-\mathrm{Eu}=58,5 ; \mathrm{Goc}=41,2 ; \mathrm{Occ}=17,1 ; \mathrm{P}-\mathrm{St}=105,0 ; \mathrm{Gpb}=63,5\end{array}$ \\
\hline & & mandibula & $\sin$. & $\mathrm{GL}=153,5 ; \mathrm{P} 1-4=41,0 ; \mathrm{M} 1-3=37,1$ \\
\hline & & scapula & $\sin$. & $\mathrm{GLP}=33,2$ \\
\hline & & scapula & dex. & $\mathrm{GLP}=32,5$ \\
\hline & & humerus & $\sin$. & $\begin{array}{l}\mathrm{GL}=174,0 ; \mathrm{BP}=44,0 ; \mathrm{DP}=34,2 ; \mathrm{SB}=15,5 ; \mathrm{SD}=13,1 ; \mathrm{BD}=37,0 ; \\
\mathrm{DD}=27,1\end{array}$ \\
\hline & & humerus & dex. & $\begin{array}{l}\mathrm{GL}=172,0 ; \mathrm{BP}=44,5 ; \mathrm{DP}=33,8 ; \mathrm{SB}=15,7 ; \mathrm{SD}=13,0 ; \mathrm{BD}=36,9 ; \\
\mathrm{DD}=27,2\end{array}$ \\
\hline & & radius & $\sin$. & $\begin{array}{l}\mathrm{GL}=179,2 ; \mathrm{BP}=19,5 ; \mathrm{DP}=13,5 ; \mathrm{SB}=13,9 ; \mathrm{SD}=7,5 ; \mathrm{BD}=26,9 ; \\
\mathrm{DD}=16,5\end{array}$ \\
\hline & & pelvis & $\sin$. & $\mathrm{GL}=157,0 ; \mathrm{LAR}=27,0$ \\
\hline & & femur & $\sin$. & $\begin{array}{l}\mathrm{GL}=194,2 ; \mathrm{BP}=39,2 ; \mathrm{DP}=20,0 ; \mathrm{SB}=13,8 ; \mathrm{SD}=13,2 ; \mathrm{BD}=38,7 ; \\
\mathrm{DD}=34,1\end{array}$ \\
\hline & & femur & dex. & $\begin{array}{l}\mathrm{GL}=196,1 ; \mathrm{BP}=40,7 ; \mathrm{DP}=20,9 ; \mathrm{SB}=13,8 ; \mathrm{SD}=13,2 ; \mathrm{BD}=39,0 ; \\
\mathrm{DD}=34,2\end{array}$ \\
\hline & & tibia & $\sin$. & $\begin{array}{l}\mathrm{GL}=194,7 ; \mathrm{BP}=38,5 ; \mathrm{DP}=38,1 ; \mathrm{SB}=13,1 ; \mathrm{SD}=13,0 ; \mathrm{BD}=24,2 ; \\
\mathrm{DD}=18,6\end{array}$ \\
\hline & & tibia & dex. & $\begin{array}{l}\mathrm{GL}=193,1 ; \mathrm{BP}=38,6 ; \mathrm{DP}=38,0 ; \mathrm{SB}=13,5 ; \mathrm{SD}=14,0 ; \mathrm{BD}=23,9 ; \\
\mathrm{DD}=18,6\end{array}$ \\
\hline \multirow[t]{6}{*}{18.} & macska & humerus & $\sin$. & $\begin{array}{l}\mathrm{GL}=87,2 ; \mathrm{BP}=14,5 ; \mathrm{DP}=14,2 ; \mathrm{SB}=7,1 ; \mathrm{SD}=5,2 ; \mathrm{BD}=16,1 ; \\
\mathrm{DD}=9,1\end{array}$ \\
\hline & & ulna & dex. & $\mathrm{GL}=102,1$ \\
\hline & & pelvis & $\sin$. & $\mathrm{GL}=68,5 ; \mathrm{LAR}=9,8$ \\
\hline & & femur & dex. & $\begin{array}{l}\mathrm{GL}=87,5 ; \mathrm{BP}=17,8 ; \mathrm{DP}=8,5 ; \mathrm{SB}=7,1 ; \mathrm{SD}=6,9 ; \mathrm{BD}=15,2 ; \\
\mathrm{DD}=16,5\end{array}$ \\
\hline & & tibia & $\sin$. & $\begin{array}{l}\mathrm{GL}=106,1 ; \mathrm{BP}=17,1 ; \mathrm{DP}=15,0 ; \mathrm{SB}=6,5 ; \mathrm{SD}=5,9 ; \mathrm{BD}=12,9 ; \\
\mathrm{DD}=8,9\end{array}$ \\
\hline & & tibia & dex. & $\begin{array}{l}\mathrm{GL}=106,0 ; \mathrm{BP}=17,0 ; \mathrm{DP}=16,0 ; \mathrm{SB}=6,5 ; \mathrm{SD}=5,2 ; \mathrm{BD}=12,1 ; \\
\mathrm{DD}=8,2\end{array}$ \\
\hline 44. mellől & ló & lapocka & & $\mathrm{GLP}=96,5$ \\
\hline 46. mellől & szarvasmarha & metacarpus & dex. & $\begin{array}{l}\mathrm{GL}=185,0 ; \mathrm{BP}=50,9 ; \mathrm{DP}=33,9 ; \mathrm{SB}=27,8 ; \mathrm{SD}=21,9 ; \mathrm{BD}=54,1 ; \\
\mathrm{DD}=24,5\end{array}$ \\
\hline
\end{tabular}

${ }^{1}$ DreisCH 1976 alapján.

\section{IRODALOM}

B. SZABÓ JÁNOS

2007 A tatárjárás. A mongol hódítás és Magyarország. Budapest (újabb kiadások: 2010, 2016).

BARTOSIEWICZ, LÁSZLÓ

2013 Shuffling Nags, Lame Ducks. The Archaeology of Animal Disease. Oxbow Books. Oxford.

BERTALAN ViLMOSNÉ

1998 XIII. századi csuklós bronzmérlegek Óbudán (Bronzeklappwaagen aus dem 13. Jahrhundert). Budapest Régiségei (Budapest) 32, 171-180.

BOROSY ANDRÁS

1991 Történetírók a tatárjárásról. Hadtörténeti Közlemények (Budapest) 104, 1991, 3-21.

CARpini, Johannes De Plano

[1981] Az általunk tatároknak nevezett mongolok históriája. In: Katona T. (szerk.): A tatárjárás emlékezete. Budapest, 214-276.

CSÁKI ÁRPÁD

2010 Szárazság és pestis Háromszéken 1717-1720-ban. Acta Siculica (Sepsiszentgyörgy) 277-287.

DINNYÉS ISTVÁN

1994 XIII. századi ház a tápiógyörgyei Ilike parton (Ein Haus aus dem 13. Jahrhundert am Ufer von Ilike in Tápiógyörgye). Studia Comitatensia (Szentendre) 23, 101-118. 
DREISCH, VON DEN, ANGELA

1976 Guide to the Measurement of Animal Bones from Archaeological Sites. Peabody Museum Bulletin 1. Peabody Museum of Archaeology and Ethnology. Harvard University.

ENGEL PÁL

2001 Szent István birodalma: a középkori Magyarország története. Budapest.

FÉLEGYHÁZY JÓZSEF

1943 A Váci püspökség a tatárjáráskor. In: Vác egyházmegye múltjából II. Vác, 7-160.

FETTICH NÁNDOR

1968 Ötvösmester hagyatéka Esztergomban a tatárjárás korából (Hinterlassenschaft eines Goldschmiedes in Esztergom aus der Zeit des Tatareneinfalles). Komárom Megyei Múzeumok Közleményei (Tatabánya)

FODOR, ISTVÁN $1,157-196$.

1975 Vorlaufige Bericht über die Ausgrabung des Dorfes Szabolcs-Kisfalud im Jahre 1971-73. Folia Archaeologica (Budapest) 26, 171-182.

1976 Vorbericht über die Ausgrabungen am Szabolcs-Vontatópart und in Szabolcs-Kisfalud. Acta Archaeologica Academiae Scientiarium Hungaricae (Budapest) 28, 371-382.

FÜGEDI ERIK

1992 A tatárjárás demográfiai következményeiről. In: Nagy B. (szerk.): Tatárjárás. Budapest, 498-499.

Guillelmus De NANGiaco

[1981] IX. Lajos király története (részlet). In: Katona T. (szerk.): A tatárjárás emlékezete. Budapest, 206.

GULYÁs GYÖNGYI

2014 Egy elpusztult tatárjáráskori ház Cegléd határában. In: ROSTA-V. SzÉKELY 2014, 29-56.

GuLYÁs GYÖNGYI-GALLINA ZsOLT

2014 Magányos kun lósír Csanádpalotáról. In: ROSTA-V. SZÉKELY 2014, 151-168.

GuZMAN, G. GREGORY

1991 Reports of Mongol Cannibalism in the Thirteenth-century Latin Sources: Oriental Factor, Western Fiction? In: Westrem, Scott D. (ed.): Discovering New Worlds: Essays on Medieval Exploration and Imagination. New York, 31-68.

GYÖRFFY GYÖRGY

1963 Magyarország népessége a honfoglalástól a XIV. század közepéig. In: Kovacsics J. (szerk.): Magyarország történeti demográfiája. Budapest.

Gyucha ATtila-RÓzSA ZOLTÁN

2014 "Egyesek darabokra vágva, egyesek egészben” - A tatárjárás nyomainak azonosítási kísérlete egy délalföldi településen. In: ROSTA-V. SZÉKELY 2014, 57-68.

HEILIGENKREUTZI ÉVKÖNYV

[1981] A heiligenkreutzi évkönyvek folytatása, 1234-1266 (részlet). In: Katona T. (szerk.): A tatárjárás emlékezete. Budapest, 202-204.

HILLSON, SIMON

1986 Teeth. Cambridge University Press. Cambridge.

JAKAB ATTILA

2007 Tatárjárás kori kincslelet Tyukod-Bagolyvárról (Hortfund aus der Zeit des Mongolen Einfalls in TyukodBagolyvár). Jósa András Múzeum Évkönyve (Nyíregyháza) 49, 247-296.

KÁRPÁTI ZolTÁN

2002 Árpád-kori majorság Budaújlak területén (Arpadian Age Manor in the Area of Budaújlak). Budapest Régiségei (Budapest) 35, 587-615.

KÉPES KRÓNIKA

[2003] Képes Krónika (részlet). In: Nagy B. (szerk.): Tatárjárás. Budapest, 209-210.

KovÁCs ÉvA

1973 Két 13. századi ékszerfajta Magyarországon (Two 13th-century Types of Jewel in Hungary). Ars Hungarica (Budapest) 67-95.

LASZLOVSZKY JÓZSEF

2003 Tatárjárás és régészet. In: Nagy B. (szerk.): Tatárjárás. Budapest, 453-468.

2007 Az ország pusztulása. In: Ritoók Ágnes - Garam Éva (szerk.): A tatárjárás. Budapest: Magyar Nemzeti Múzeum, 39-43.

2012 A magyarországi tatárjárás régészeti emlékei - autópálya-építés és régészeti kutatás. Magyar Régészet Online Magazin, Tavasz.

LASZlOvSZKY, JózSEF-Pow, STEPHEN-PuszTAi, TAMÁs

2016 Reconstructing the Battle of Muhi and the Mongol Invasion of Hungary in 1241: New Archaeological and Historical Approaches. https://www.researchgate.net/publication/320346497_ RECONSTRUCTING_THE_BATTLE_OF_MUHI_AND_THE_MONGOL_INVASION_OF_ HUNGARY_IN_1241_New_Archaeological_and_Historical_Approaches 
LYUBLYANOVICS, KYRA

2017 New Home, New Herds. Cuman Integration and Animal Husbandry in Medieval Hungary from an Archaeozoological Perspective. Archaeopress Archeology, Archaeolingua.

MARTINUS OPPAVIENSIS

(1981) Krónika a pápákról és császárokról 1277. (Részlet) In: Katona T. (szerk.): A tatárjárás emlékezete. Budapest, 207.

MÉRI ISTVÁN

1954 Árpád-kori pénzváltó mérleg. Folia Archaeologica (Budapest) 4, 106-114.

MiKLÓs ZSUZSA

1981 Árpád kori földvár Mende-Leányváron (Die arpadenzeitliche Erdburg von Mende-Leányvár).

1991 Archaeologiai Értesítő (Budapest) 108, 233-250.

1991 13. századi nemesi udvarház Tura-Szentgyörgyparton (Der Herrenhof von Tura-Szentgyörgypart ausdem XIII. Jahrhundert). Studia Comitatensia (Szentendre) 21, 433-456.

\section{MTT}

1962 Mongolok Titkos Története. Ford.: Ligeti Lajos. Budapest.

Yvo De NARBONNE

[2003] Yvo de Narbonne Gerard bordeaux-i érseknek. In: Nagy B. (szerk.): Tatárjárás. Budapest, 168-171.

NeWTON, CHARLES D.-NunAMAKER, DAVID M.

1985 Textbook of Small Animal Orthopaedics http://cal.vet.upenn.edu/projects/saortho/index.html

PARÁDI NÁNDOR

1975 Pénzekkel keltezett 13. századi ékszerek. A nyíregyháza-pusztapótharaszti kincslelet (Münzdatierte Schmuckstücke aus dem 13. Jahrhundert. Der Schatzfund von Nyáregyháza-Pusztapótharaszt). Folia Archaeologica (Budapest) 26, 119-161.

Planctus

[2003] Planctus destructionis regni Hungariae per Tartaros. In: Nagy B. (szerk.): Tatárjárás. Budapest, 157-162.

POZSONYI KRÓNIKA

[2003] Pozsonyi Krónika (részlet). In: Nagy B. (szerk.): Tatárjárás. Budapest, 210.

PRICE, MERRALl LLEWELYN

2003 Consuming Passions. The Uses of Cannibalism in Late Medieval and Early Modern Europe. In: Francis,

PuszTai TAMÁs

Gentry G. (ed.): Studies in Medieval History and Culture 20. New York-London.

2014 Buzogánnyal, tarsollyal és késtok-merevítóvel eltemetett halott a muhi csatából. In: ROSTA-V. SZÉKELY 2014, 141-150.

RiTOÓK ÁGNES-GARAM ÉVA

2007 A tatárjárás. Kiállítási katalógus. Budapest.

ROGERIUS

[2003] Rogerius mester siralmas éneke. In: Nagy B. (szerk.): Tatárjárás. Budapest, 129-157.

Rosta SZABOLCS

2014 Pétermonostora pusztulása. In: RosTA-V. SzÉKELY 2014, 193-230.

RosTA SZABOLCS

2017 Árpád-kori kézi mérlegek Pétermonostorán. In: Kádas I.-Weisz B. (szerk.): Hatalom, adó, jog. Gazdaságtörténeti tanulmányok a magyar középkorról. MTA Bölcsészettudományi Kutatóközpont Történettudományi Intézet. Budapest, 125-153.

ROSTA SZABOLCS-V. SZÉKELY GYÖRGY

2014 (Szerk.): „Carmen Miserabile”. A tatárjárás magyarországi emlékei. Tanulmányok Pálóczi Horváth RUBENSTEIN, JAY András 70. születésnapja tiszteletére. Kecskemét, 69-80.

2008 Cannibals and Crusaders. French Historical Studies (South Carolina) 31, 525-552.

SCHMID, ELISABETH

1972 Atlas of Animal Bones: For Prehistorians, Archaeologists and Quaternary Geologists. Elsevier Publishing Co. Amsterdam-London-New York.

SCHMIEDER, FELICITAS

2005 Menschenfresser und andere Stereotypies Gewalttätiger Fremder - Normannen, Ungarn und Mongolen (9.-13. Jahrhundert). In: Braun, M.-Herberichs, C. (Hrsg.): Gewaltim Mittelalter, Realitäten Imagiationen. München, 159-180.

SILVER, IAN

1963 The Aging of Domestic Animals. In: Brothwell, D.-Higgs, E. S.-Clark, G. (eds): Science in Archaeology: A Survey of Progress and Research. London, 283-302.

SPALATÓI

[2003] Spalatói Tamás: A salonai és spalatoi főpapok története (részlet). In: Nagy B. (szerk.): Tatárjárás. Budapest, 52-65. 
STEUER, HEIKO

1997 Waagen und Gewichte aus den mittelalterlichen Schleswig. Funde des 11. bis 13. Jahrhundert aus Europa als Quellen zur Handels und Währungsgeschichte. Zeitschrift für Mittelalter Beiheft 10.

SZABÓ ISTVÁN

1971 A falurendszer kialakulása Magyarországon (X-XV. század). Budapest.

SZABÓ LÁSZLÓ

2003 Megjegyzések a böszörményiek kérdéséhez a Hajdúböszörmény határában talált Árpád-kori falu régészeti leletei alapján (Anmerkungen zur Böszörmény-Frage auf Basis der archäologischen Funde eines im Weichbild von Hajdúböszörmény entdeckten arpadenzeitlichen Dorfes). Debreceni Déri Múzeum Évkönyve (Debrecen) 2002-2003, 78-108.

SZEPESSZOMBATI KRÓNIKA

[2003] Szepesszombati Krónika (részlet) In: Nagy B. (szerk.): Tatárjárás. Budapest, 210-211.

SZILÁGYI, MAGDOLNA

2012 Perished Árpádian-age Village at Dunaföldvár. Acta Archaeologica Academiae Scientiarium Hungaricae (Budapest) 63,155-180.

SZILÁGYi MAgDOLNA-SERLEGI GÁBOR

2014 Nád közé bújtak...? Egy a tatárjárás során elpusztult település maradványai Dunaföldvár határában. In: ROSTA-V. SZÉKELY 2014, 127-140.

SZÜCS JENŐ

1993 Az utolsó Árpádok. Budapest.

TATÁRJÁRÁS

2003 Tatárjárás. Szerk.: Nagy B. Budapest.

TATÁRJÁRÁS EMLÉKEZETE

1981 A tatárjárás emlékezete. Szerk.: Katona T. Budapest.

VARGHA, MÁRIA

2015 Hoards, Grave Goods, Jewellery: Objects in Hoards and in Burial Contexts during the Mongol Invasion of Central-Eastern Europe. Budapest-Oxford.

SZ. WILHELM GÁBOR

2014 "Akiket nem akartak karddal elpusztítani, túzben elégették." Az 1241. évi pusztítás Szank határában. In: ROSTA-V. SZÉKELY 2014, 81-109.

Wolf MÁRIA

1997 Hejőkeresztúr-Vizekköze. Árpád-kori település a XI-XII. századból (Hejőkeresztúr-Vizeköze. Settlement of the Árpád period from the 11th-13th century). In: Raczky P.-Kovács T.-Anders A. (szerk.): Utak a múltba (Paths into the past). Az M3-as autópálya régészeti leletmentései (Rescue excavations on the M3 motorway). Budapest, 139-143.

1999 Árpád-kori település Hejőkeresztúr határában (Ansiedlung in der Feld für Hejőkeresztúr aus der Arpaden-Zeit). In: Perémi Á. (szerk.): A népvándorláskor fiatal kutatói 8. találkozójának előadásai. Veszprém, 1997. november 28-30. Veszprém, 166-178.

2014 Régészeti adatok a muhi csata történetéhez. In: ROSTA-V. SzÉKELY 2014, 69-80.

ZICHY LADOMÉR

1934 A tatárjárás Magyarországon. Budapest.

\section{NEW ASPECTS OF THE ARCHAEOLOGY OF THE MONGOL INVASION OF HUNGARY}

\section{SZABOLCS ROSTA}

The Mongol invasion (1241-1242) is a determinant feature of Hungarian historical heritage, which is still vividly present in collective remembrance after 800 years. In accordance with its significance, the events had been described and interpreted from various aspects in historical studies. Generations of historians debated the feasibility of contemporary documentary sources, argued the level of destruction caused by the Tartars, and analysed the short- as well long-term consequences of the events.

As compared to the richness of the written source material, for a long time Hungarian archaeology could not show up any factual evidences connected to the Mongol invasion of Hungary. The contemporary, often apocalyp- tic accounts regularly report on mortified ruins and mass murders, yet the definite and credible traces of such actions were not verified by archaeological research for a long time. Accordingly, the scant features directly connectable to the attack of the Mongols, the lack of confirmed data, the limited find material strengthened those opinions which concluded that the narratives of the contemporary witnesses are exaggerations in terms of the extension and intensity of destruction, thus their information cannot be used for the reconstruction of the events, or must be cautiously filtered in interpretations. The large-scale rescue excavations (motorways, transmission-lines) from the 1990s brought a major development 
in the archaeological research of the Mongol invasion. The results from these surveys partly resulted a significant rise in the detection of human and other destructions from that period, besides, allowed for the interrelation of similar features observed at individual sites. Today approximately a dozen formerly unknown sites can be listed which produced the complex and direct evidences on the actions.

The present study focuses on two sites, both surveyed in 2016, which provided new noteworthy results in the archaeological research of the Mongol invasion. The in- terpretation of the excavated features was exceedingly assisted by the outcomes of the last decades' investigations. What is more, based on the previous surveys and the new research results, it is now possible to deduce some characteristic motives of the destruction.

The archaeological traces of massacres documented at the monastery of Bugac and Kiskunmajsa, provide new deadly realistic insight into the period of the Mongol invasion. Beyond this, these latest results offer some new directions for the investigation of credibility of contemporary documents. 